\author{
Universidade de São Paulo \\ Faculdade de Filosofia, Letras e Ciências Humanas \\ Departamento de Letras Modernas \\ Programa de Pós-Graduação em Língua Espanhola e \\ Literaturas Espanhola e Hispano-Americana
}

ANDREA AUGUSTA DE AGUIAR

\title{
O discurso de Celestina: a \\ construção e a desconstrução da
}

personagem

V.1

São Paulo

2011

"Versão corrigida" 


\title{
ANDREA AUGUSTA DE AGUIAR
}

\section{O discurso de Celestina}

\author{
Dissertação apresentada ao \\ Programa de Pós-Graduação em Língua \\ Espanhola e Literaturas Espanhola e \\ Hispano-Americana do Departamento \\ de Letras Modernas da Faculdade de \\ Filosofia, Letras e Ciências Humanas da \\ Universidade de São Paulo para a \\ obtenção do título de Mestre.
}

Orientador: Prof. Dr. Mario Miguel González

V.1

São Paulo

2011

"Versão corrigida" 
Catalogação na Publicação

Serviço de Biblioteca e Documentação

Faculdade de Filosofia, Letras e Ciências Humanas da Universidade de São Paulo

Aguiar, Andrea Augusta de

O discurso de Celestina: a construção e a

desconstrução da personagem / Andrea Augusta de Aguiar ;

orientador Mario Miguel González. - São Paulo, 2011.

$152 \mathrm{f}$.

Dissertação (Mestrado) - Faculdade de Filosofia, Letras e Ciências Humanas da Universidade de São Paulo. Departamento de Letras Modernas. Área de concentração: Língua e Literatura Espanhola e HispanoAmericana.

1. Literatura espanhola. 2. Análise do discurso. 3. Personagens. 4. Persuasão. 5. Rojas, Fernando de, d. 1541. I. Título. II. González, Mario Miguel.

CDD 862 
Dedico esta monografia a minhas filhas que me ensinaram a brincar e aos meus pais e meu irmão que sempre me incentivaram a estudar. 


\section{Agradecimentos}

À Natalia Lisboa Carvalho, pelo ponta-pé inicial.

À Sirlene Martinez, pela gigante colaboração na reta final.

Às amizades conquistadas pelos caminhos das disciplinas cursadas nesta Faculdade e aos professores que as ministraram.

Em especial, à professora María de La Concepción Piñero Valverde, pelas oportunidades.

À professora Lineide Salvador Mosca, pelas orientações na Qualificação.

Ao meu orientador, professor Mario Miguel González. 


\section{SUMÁRIO}

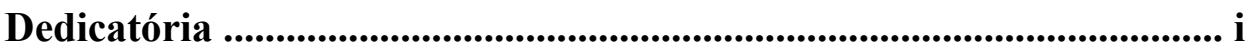

Agradecimentos .............................................................................................. ii

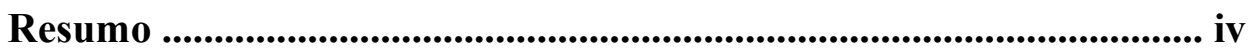

Abstract .........................................................................................................

Índice

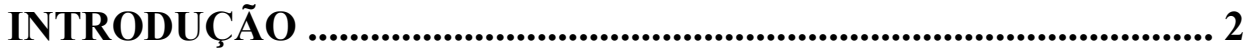

I. O PERSONAGEM CELESTINA _....................................................... 19

II. A CONSTRUÇÃO DE CELESTINA ............................................ 55

III. A DESCONSTRUÇÃO DE CELESTINA ...................................... 86

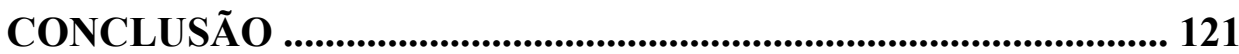

ANEXOS ........................................................................................................ 123

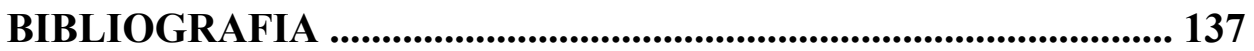




\section{Resumo}

A investigação $O$ Discurso de Celestina tem a finalidade de estabelecer dialogicamente as relações entre representações sociais, ideologia e elementos linguísticos que unem a protagonista Celestina à enunciação. Essas relações se concretizam no seio das esferas literária e histórico-social. Com esse propósito foi feito um recorte na perspectiva discursiva, espaço em que se efetiva uma série de relações de poder por intermédio das ações de Celestina. O discurso deste personagem, persuasivo por excelência, emerge da crise dos valores renascentistas, na obra La Celestina, editada pela primeira vez em 1499 e escrita por Fernando de Rojas, judeu converso, em Salamanca, Espanha. O discurso desta protagonista parece revelar a voz do autor que ora desvenda, ora encobre suas intenções, seus interesses e contextos. Seu conteúdo é redefinido e ou esvaziado, o que valoriza seu caráter paradoxal e irônico, como reflexo da cultura humanística de Rojas. Recorremos à Análise do Discurso para abordar os elementos da Nova Retórica que dessem conta do éthos discursivo de Celestina e, no seio dessa análise, nos deparamos com elementos dos mais diversos campos de estudo; destacamos, dentre eles, a parte da que analisa a reformulação textual da segunda carta de Sêneca a Lucílio sobre a diversidade da leitura e a parte que identifica os elementos do esperpento de Valle Inclán. Para concluir, reconhecemos que a persuasão é a principal característica do discurso de Celestina para alcançar seus objetivos pessoais e que ela é um personagem que se constrói e se destrói em seu discurso e por intermédio dele.

Palavras-Chave: Celestina. Discurso. Personagem. Diálogo. Persuasão. 


\begin{abstract}
The research The Celestina speech aims to establish a dialogue relations between social representation, ideology and linguistic elements that unite the enunciation to the protagonist Celestina. These relationships are materialized within the ball literary, social historical. For this purpose a cut was made in view discursive space in which an effective series of power relations though the Celestina's actions. The speech of this character, persuasive par excellence, emerging from the transition period to the Renaissance. The book La Celestina was written around 1498 in Salamanca, Spain, by Fernando de Rojas, a Jewish convert. This speech is the real protagonist, as it reveals the author's voice, that sometimes unravels and conceals his intentions, interest and backgrounds. Its contest is reset or empty and that values its ironic and paradoxical character, reflecting that episodic memory. We appeal to the discourse analysis to address the elements of the New Rhetoric devised to address the discursive ethos of Celestina and within this analysis, we encounter elements of many fields of study, we have emphasized, among them the part of the research that identifies elements of Valle Inclán Esperpento and textual study of the reformulation of the second Seneca's letter to Lucilius about the diversity of reading. To conclude, we recognize that persuasion is the hallmark of Celestina's speech to achieve her personal goals and she is a character who builds and destroys in her speech and through it.
\end{abstract}

Keywords: Celestina. Speech. Character. Dialogue. Persuasion. 
Índice

INTRODUÇÃO

Os desafios

A proposta

A contribuição

A organização

\section{O PERSONAGEM CELESTINA}

Introdução

1. Celestina - uma leitura do personagem

2. Celestina à luz da história social

3. A literariedade no tema celestinesco

4. Celestina: voz e corporalidade

Conclusão

\section{A CONSTRUÇÃO DE CELESTINA}

Introdução

1. O éthos discursivo de Celestina

2. O processo de corrupção de Pármeno

Conclusão

\section{A DESCONSTRUÇÃO DE CELESTINA}

Introdução

1. A intervenção do discurso do outro no processo de desconstrução de Celestina no discurso

1.1. Os indícios da falta de acordo

1.2. A falta de acordo - o último diálogo de Celestina

Conclusão

CONCLUSÃO

ANEXOS

BIBLIOGRAFIA 


\section{INTRODUÇÃO}

Los pliegues del corazón y del cerebro de una vieja. La trampa. La femineidad vuelta astucia cuando ya la carne ha dejado de ser carne y es sólo una materia indescriptible. La celestina que es celestina para no morir de hambre [...] (MARTÍN-SANTOS. Tiempo de Silencio, 2001, p.95).

O narrador sobre a velha dona da pensão. 


\section{Os desafios}

O primeiro e grande desafio desta pesquisa é o de enfrentar, por uma parte, a pluralidade crítica do material existente, resultado da grandiosidade da obra $\mathrm{La}$ Celestina no cenário da literatura espanhola e, por outra parte, no âmbito particular desta pesquisa, as questões do discurso do personagem Celestina na obra única de um possível autor de origem conversa no fim do século XV, Fernando de Rojas.

Concomitantemente a esses enfrentamentos circunscrevemos do corpus maximal $^{l}$, aquele que contempla todo o discurso do personagem, o nosso corpus delimitado com o objetivo de integrar as interrogantes: à luz da literariedade, por que o personagem não resiste sem o seu discurso persuasivo? Se Celestina não existe sem a sua argumentação persuasiva, quais são os motivos da cena enunciativa que a levam a perder suas conquistas e fracassar como enunciadora, sobretudo no diálogo com Pármeno e Sempronio, seus aliados? À luz da história social, quais são os valores daquela sociedade expressos no razoamento do personagem que o fazem ora mais ora menos persuasivo?

O próximo desafio está na investigação do discurso não e tão somente dentro do campo linguístico, da construção do texto e do processo artístico dado pelo autor, mas também e principalmente, dentro da articulação dos saberes que se referem ao campo no qual ele é proferido com os conhecimentos elaborados e produzidos pelas ciências da linguagem. Consequentemente, a partir dessas premissas, o desafio de extrair a independência do discurso do ser ficcional.

Entretanto, é imprescindível levantar algumas questões iniciais como a de esclarecer o que se entende por discurso no âmbito da nossa investigação e distinguir quando ele é atribuído ou não ao personagem. Tão imprescindível quanto a caracterização da argumentação de Celestina é delimitar o recorte para enfocá-lo à luz de vários campos: o da historicidade, o da literariedade e o das ciências da linguagem.

O discurso de Celestina é a exposição, não de uma tese, mas sim dos seus objetivos em causa própria de maneira metódica e velada sem compromisso com a verdade. Para alcançar as suas proposições pessoais como enunciadora, ela influência as paixões dos seus destinatários no espaço específico da

\footnotetext{
${ }^{1}$ Noções definidas por Maingueneau (1997) sobre o corpus maximal, o delimitado e o
} elaborado. 
materialização dos valores ideológicos dos grupos sociais dos amos e dos criados, estratos sociais presentes no período em que a obra se insere. O personagem, como sujeito da enunciação, é uma entidade que se constrói no seu discurso e por intermédio dele, lugar do qual se permite analisar os traços retóricos constitutivos de sua identidade, seu éthos discursivo, sob as dimensões ética, estética e dialética.

Acrescentamos às questões introdutórias, o nosso intuito de abordar teoricamente alguns termos insistentemente empregados ao longo dessa investigação em virtude da delimitação do corpus em argumentação com maior e menor grau de persuasão. Os termos discurso retórico, persuasão e técnicas argumentativas estão diretamente associados aos diálogos, microdiálogos, monólogos interiores, apartes e solilóquios do personagem Celestina, pois comportam os pontos mais controvertidos e passíveis de discussão. A argumentação está ligada à ideia de liberdade de dizer o que se pensa e de contradizer o pensamento do outro; portanto, volta-se para o verossímil, para o que é plausível e razoável e não tem compromisso com a verdade e sim com os efeitos de verdade que possa causar no auditório.

Por outro lado e mais além da questão do gênero híbrido - conceito que não nos propomos a analisar, embora acreditemos na antecipação da evolução de um gênero literário moderno em La Celestina —, reconhecemos que a presença do diálogo dinâmico e teatral nesta obra está de acordo com o que Galdós ${ }^{2}$ (1897:205-7) descreve no prólogo de El Abuelo sobre sua relação com Realidade (1889) e a obra em questão, coincidentemente com a nossa análise, a de obra de precursora:

[...] el sistema dialogal, adoptado ya en Realidad, nos da la forma expedita y concreta de los caracteres [...] aunque por su estructura y división en jornadas y escenas parece El Abuelo obra teatral, no he vacilado en llamarla novela, sin dar a las denominaciones un valor absoluto [...] que me diga también el que lo sepa si $L a$ Celestina es novela o drama. Tragicomedia la llamó su autor, "drama de lectura" es, realmente, y, sin duda, la más grande y bella de las novelas habladas. Resulta que los nombres existentes nada significan, y en la literatura la variedad de formas se sobrepondrá siempre a las nomenclaturas que hacen a su capricho los retóricos.

${ }^{2}$ Cabe destacar que Galdós escreveu uma das muitas continuações textuais de $L a$ Celestina, La razón sinrazón (1915), obra em que a feiticeira Celeste parece uma reencarnação de Celestina. 
Portanto, à parte da questão do gênero, assim como a arte da conversação é a grande protagonista de La Celestina, a retórica da palavra compõe o universo da criação verbal de Fernando de Rojas em sua obra, na qual a conversação é sempre resultante de uma atividade interpessoal desenvolvida entre pelo menos dois personagens em situação face a face, dentro de uma configuração contextual de que fazem parte os entornos espaço-temporal e histórico-social que os unem. O autor, ao ceder o protagonismo à voz dos personagens e na inexistência de um narrador, revela e ou oculta o espaço, o tempo e a interioridade dos personagens unicamente através da linguagem. Rojas expressa o jogo de revelação e ocultação dos elementos da trama por meio da linguagem verbal - diálogos, monólogos interiores, apartes, das réplicas e solilóquios — e da linguagem não verbal - a cicatriz $^{3}$ no rosto do personagem, o feitiço e o conjuro a Plutão e as reações involuntárias provindas do inconsciente dos destinatários as quais não são ditas.

Entretanto, podemos afirmar que a voz do autor se revela na "Carta del autor a su amigo", no Prólogo, no Argumento Geral que antecede o primeiro ato e nas oitavas que inciam e encerram a obra. Nesses momentos Rojas explica o gênero textual do manuscrito anônimo, a intenção doutrinária e moralizante de ensinar deleitando o exemplo a não ser seguido, o exemplum ex contrariis, por amantes que confiam em alcoviteiras e falsos criados.

A voz e a corporalidade de Celestina são reconhecidas pela propriedade enunciativa do seu razoamento persuasivo e a caracterizam como enunciadora dos diálogos retóricos constantemente sustentados por réplicas com impressionante poder de convencimento. O personagem se constrói dentro da sua argumentação com a intervenção da réplica do outro, tornando-o mais persuasivo. Portanto, nesse contexto podemos inferir que o outro também tem autoridade para desconstruir o personagem no âmbito discursivo quando este não exerce suficientemente o fazer argumentativo eficaz a ponto de persuadi-lo.

Escolhemos o tema da construção de Celestina no seu discurso para analisar os processos de constituição e evolução desse discurso inserido no contexto específico da obra e da história social. Enriquecidos pela mudança da

${ }^{3} \mathrm{O}$ aspecto físico grotesco causado pela cicatriz no rosto reflete a deformação espiritual de Celestina a qual será tratada no Capítulo I sobre o personagem ao traçar um diálogo com as características do esperpento de Valle-Inclán. 
trajetória argumentativa e suas consequências sobre si e sobre os demais personagens, sem a pretensão de causar um efeito antifrásico, estendemos o tema para incluir a desconstrução com a degradação do razoamento do personagem. Com isso, nossos objetivos alcançam explicar essas mudanças associadas a fatores individuais do personagem e de seus interlocutores como os fatores físicos, os valores psicológicos e os fatores sociais, históricos, estéticos e pragmáticos, os que estão intrínsecos à linguagem verbal e não verbal. Teremos no nosso corpus delimitado, portanto, dois corpora elaborados ${ }^{4}$ : o primeiro integrará um momento de construção e o segundo, o da desconstrução ${ }^{5}$ do personagem no discurso.

Com o objetivo de realizar uma reflexão crítica sobre a construção e a desconstrução do personagem no processo discursivo procuramos indícios que revelassem os detalhes aparentemente irrelevantes e marginais da exposição verbal e não verbal dos personagens para formular as questões a serem desveladas. Trata-se de um processo inferencial que parte das particularidades surpreendentes do discurso, que fogem à regra geral das ciências humanas e sociais, e desembocam em hipóteses, algumas sem força comprobatória.

Com uma questão em mãos: a de como Celestina se constrói e desconstrói discursivamente, ou seja, quando sua argumentação é mais ou menos persuasiva, esta pesquisa se encaminhou para a seleção dos materiais a serem analisados. Assim, é feita a interpelação às ciências da linguagem para recortar o corpus cujo limite não prima por ser estável. Antes, porém, a caracterização dos corpora elaborados é fundamental para distingui-los entre os momentos em que a maior persuasão leva ao auge da temática do amor erótico na obra, isto é, a da satisfação do desejo carnal com o gozo da paixão e, consequentemente, a menor persuasão

${ }^{4}$ Tomamos a definição de Maingueneau (1997) de corpus "elaborado” para o texto que selecionamos dentro do corpus delimitado e que responde às hipóteses deste trabalho, definidas por um conjunto de enunciados a partir da nossa proposta: discurso com menor e maior persuasão.

5 Ao adotar o termo "desconstrução", esclarecemos que — não tão distante embora não tenhamos procurado metodologismos, desconstrucionismos e decodificação de regras para decifrar o texto, como nas teorias de Julia Kristeva e Jacques Derrida - o empregamos porque pretendemos analisar as estruturas que desqualificam a argumentação do personagem e que o levam a deixar de construí-la tão eficazmente persuasiva quanto antes. Não queremos incorrer em erro de interpretação ao adotar, como nos objetivos desses autores, a tarefa de desmontar para reconstruir e assim, nos distanciar dos nossos objetivos: o de como Celestina deixa de construir aquele discurso que era persuasivo por excelência. 
ao desfecho moral com o esfaqueamento, cujo efeito de sentido nos aproximará do realismo grotesco. Portanto, consideramos que, se por um lado a construção do discurso mais persuasivo da mediadora amorosa refrata na obra o auge da trajetória do amor de nobres e criados, por outro, o menor grau persuasivo desconstrói a argumentação do personagem que, assim, cumpre seu ciclo vital com a punição por sua conduta imoral e carrega os demais personagens para o mesmo destino trágico. É a catarse em que não há diferença de classes sociais, pela qual Rojas purifica todas as almas por meio da tragédia.

O autor apresenta um possível conceito pessoal sobre moral na intencionalidade da obra, descrita no incipit: servir de aviso aos nobres e loucos apaixonados sobre as falsidades de alcoviteiras e maus e lisonjeiros criados. À luz da história social, o efeito de sentido didático-moralizante do incipt não leva unicamente à punição dos personagens Celestina, Pármeno, Sempronio, Calisto e Melibea - uma sequência de mortes causada, seja por amor ou por dinheiro, entre nobres e criados igualmente - , mas também leva a um fim pessimista do ciclo vital, intensamente vivido longe dos preceitos morais. Sem amor e sem dinheiro a obra parece sugerir que não há perspectiva de que surjam novas classes socioeconômicas, como a burguesa, que já se anunciava nas cidades daquele período. De fato, a crise dos valores renascentistas na Península Ibérica reafirma o poder da classe aristocrata em sustentar os ideais absolutistas dos Reis Católicos, dificultando, assim, a afirmação da nova classe, a burguesa.

Rojas vive esse período inicial da consolidação do poder ideológico castelhano, que começa em fins do século $\mathrm{XV}^{6}$ e, no caso muito peculiar da Península Ibérica quando comparado com o resto da Europa, ambiguamente confirma o modelo nacional imposto pela monarquia, critica os valores medievais parodiando a doutrina do amor cortês e, concomitantemente, não reconhece os valores renascentistas, transparecendo, assim, não ver futuro na modernidade burguesa.

${ }^{6}$ Rojas escreve La Celestina no auge dessa crise de valores na Península Ibérica. Paradoxalmente, critica os recentes valores renascentistas e burgueses - que tentavam se impor sem sucesso diante da aristocracia, a base de sustento da monarquia - , ao mesmo tempo que coexistiam com o período medieval, preservando, assim, alguns dos modelos sociais cristãos e feudais. Da mesma maneira, destacamos a opinião do historiador Jacques Le Goff quando afirma que os vestígios da Idade Média sobreviveram na Idade Moderna e, somente com a Revolução Industrial, pode-se afirmar que tais vestígios se encerraram. 
O sentido essencialmente crítico de Rojas nos leva a reconhecer que a pluralidade da obra tem produzido um mosaico de teses defendidas por críticos e teóricos, as quais causam controvérsias. Em linhas gerais, temos que Marcel Bataillon (1982) sustenta que a moral cristã domina sobre o louco amor e suas consequências. Lida Malkiel (1962) valoriza a originalidade da criação artística de Rojas sobre as origens conversas do autor que, segundo Américo Castro (1983) e Gilman (1978) estão na tese principal da obra. Contudo, Gilman afirma que o autor vê a fortuna como um universo hostil, mas Castro defende a contenda literária das três castas embora Maravall (1981) não observe a falta de integração de Rojas ao seu meio social. Do mesmo modo, Deyermond (1979) esclarece que há anacronismo em sustentar a crítica à conversão inquisitorial, uma vez que o autor pertencia já à terceira geração de conversos, ao mesmo tempo reforça a tese existencialista na ação inexorável do destino. Gurza (1977) também defende o existencialismo na obra no sentido trágico e paradoxal da vida através da ironia e da ambiguidade. Maravall (apud Rodríguez Puértolas, 1976) vê refratado no dilema entre o desejo e a obrigação, o "querer ser" e o "ter de ser" a crítica ao conflito social.

Contudo, diante dessa diversidade de opiniões, não pretendemos nesta pesquisa dar conta da gênese da obra porque, para a finalidade da nossa investigação sobre o discurso do personagem basta afirmar que, à luz dos preceitos da moral cristã, reconhecemos que no que diz respeito aos pecados capitais, o personagem apresenta sistematicamente todos os vícios de conduta reunidos, incorporados e enumerados por Tomás de Aquino no século XIII. Segundo esse teólogo, os vícios capitais têm um fim excessivamente desejável e, para alcançá-los, os homens acabam por cometer muitos outros pecados originários daqueles. É exatamente o que acontece com Celestina, embora, entre todos os erros de alvo, possamos resumidamente concluir que ela se constrói fundamentalmente movida pela cobiça e desqualifica seu discurso por obra da avareza ou da ganância.

Há vários e ricos exemplos em que Celestina se constrói no seio da exposição verbal e não verbal dos seus objetivos, porém, o mais significativo e que delimita o corpus desta pesquisa é aquele no qual a argumentação convence Pármeno a ser seu aliado. A velha astuta constrói com a intervenção das réplicas do criado uma longa argumentação persuasiva por excelência que alcança o auge 
da trajetória da temática do amor erótico na obra: o encontro amoroso entre Areúsa e Pármeno.

A mediadora Celestina não é o eixo de convergência somente entre o casal Areúsa e Pármeno. O primeiro encontro entre Melibea e Calisto também se inclui no apogeu do tema amoroso na obra, contudo, para as exposições persuasivas da alcoviteira, convencer Calisto a aceitá-la como mediadora não foi tarefa difícil diante de estratégias e recursos extralinguísticos empregados para persuadir Melibea.

Se, por um lado, temos os sucessos amorosos de Celestina como mediadora, por outro, consideramos que o menor grau de persuasão entre as suas exposições ocorre quando ela dialoga com Pármeno, exatamente porque é o mesmo, antes persuadido, quem antagoniza, ao lado de Sempronio, a desconstrução da argumentação de Celestina. Acreditamos que, para concretizar a intencionalidade anunciada no prólogo da obra, Rojas conduz a desconstrução da argumentação persuasiva do personagem aos momentos que antecedem as execuções dos pobres, a morte tragicômica de Calisto e o suicídio de Melibea, e assim pode punir os personagens pobres pela falsidade e os ricos pelas loucuras da paixão.

Acrescentamos às razões que contribuem para a escolha de um dos diálogos entre Celestina e Pármeno no corpus, o fato de este criado ser um personagem cuja trajetória psicológica é bastante flexível às transformações de pensamento e opinião, causa da sua radical mudança de comportamento ao longo da obra. Pármeno passa da condição de criado familiar, fiel a Calisto, a de um aproveitador, infiel, vingativo e invejoso serviçal, fruto do rancor social despertado por Celestina e Sempronio. Os dois criados rompem os laços feudais da estrutura social, entretanto não terminam vitoriosos. São executados em praça pública como em uma carnavalização, um ritual grotesco de destronamento, verossímil no fim do século $\mathrm{XV}$.

A evolução do caráter de Pármeno contribui para a desconstrução da argumentação persuasiva de Celestina à medida que muda a sua hierarquia de valores e cresce a tomada de consciência de si próprio: a sua juventude que antes contribuíra para aceitar o apelo sexual, agora impede a aceitação e reconhecimento da sua condição de criado, condicionado a um estrato social inferior ao de Calisto, seu amo. Por não resistir aos impulsos que o levam a 
praticar atos moralmente baixos, Pármeno atinge o auge do anti-heroísmo. Os sentimentos de rancor, causados pela hierarquia social dos estratos da época, de cobiça pelo poder econômico de Calisto, e de covardia perante a velha Celestina o levam a ser infiel diante do seu amo e diante dos princípios sociais.

Portanto, o discurso de Celestina para com Pármeno é um caso significativo que expõe a norma à particularidade de que ora persuade com eficácia, ora é menos persuasivo. O rompimento da aliança entre ambos causa o fim da argumentação e do diálogo e, consequentemente, leva à desconstrução do razoamento do personagem e ao fim do seu ciclo vital na obra. Os personagens de Rojas existem enquanto diálogo — diálogo permanentemente dinâmico — porque o significado de cada um está no que proferem e não nas suas ações.

A consequente morte de Celestina não significa o fim do personagem, primeiramente porque a temática do amor e da fortuna persiste dentro e fora da obra e, segundo, porque discursos como os da mediadora amorosa aparecem posteriormente sob a forma de reelaborações, reformulações e continuações. Ecos da estratégia persuasiva do personagem alcoviteiro repercutem internamente à obra não somente nas vozes dos personagens Areúsa e Elicia, mas também na interpretação de leitores, críticos e autores.

Somados aos ecos celestinescos que se perpetuam nas seguidas reedições, a obra de Rojas sofre várias metamorfoses textuais até chegar à atual composição. Trabalhamos com o texto íntegro da obra original com as emendas e adições da edição de 1514 em Valencia, publicado pela editora Castalia $^{7}$ em 2002: os argumentos no começo de cada ato, a carta "El autor a un su amigo", os versos acrósticos "El autor escusándose", o Prólogo, "Síguese", "Argumento de toda la obra", os vinte e um atos, "Concluye el autor" e os versos finais do corretor Alonso de Proaza.

Em curto espaço de tempo e em pontos geográficos distantes da Espanha os primeiros dezesseis atos da obra surgem em 1499 em Burgos publicados pelo impressor Fadrique de Basilea conhecidos como El argumento del primer auto desta comedia, sem título e autoria. Em 1500 Pedro de Hagenbach publica a obra em Toledo com o título Comedia de Calisto y Melibea, composta da carta "El autor a un su amigo", as coplas acrósticas de "El autor escusándose”, o "Síguese”,

${ }^{7}$ A edição adotada nesta investigação é a de Peter E. Russell, corrigida em 2001 e comentada pelos editores Marta Haro Cortés e Juan Carlos Conde. 
o "Argumento de toda la obra" e do primeiro ato e, por último, os versos finais em coplas do corretor Alonso de Proaza. Com a mesma composição, Stanislao Polonio a publica em Sevilha em 1501.

Com a inclusão de mais cinco atos, a obra surge com o título Tragicomedia de Calisto y Melibea, publicada por Eucario Silber em uma versão em italiano por Alfonso Ordónez em 1506, com base em uma edição perdida de 1502, de Toledo. Desde 1998 se conhece um novo exemplar preservado em uma biblioteca privada da edição espanhola da Tragicomedia publicada em Zaragoza em 1507 e editada por Jorge Coci. Em 1514 em Valencia se imprime uma primeira edição completa, revisada e corrigida da Tragicomedia por Alonso de Proaza, o mesmo revisor da edição de 1501. Em 1526 surge em Toledo uma edição com 22 atos, em razão do acréscimo na obra do "Auto de Trasso" que não se atribui a Fernando de Rojas. Até finalmente ser publicada como La Celestina — a primeira tradução francesa, em 1527, intitulada Celestine -, a obra passa por várias edições espanholas e traduções ao francês, italiano, alemão, flamenco, hebraico, inglês e latim graças à força do personagem diante dos leitores da época que a tornou um clássico editorial.

Entretanto, o título da obra era conhecido no meio jurídico por Melibea. É assim como aparece no processo inquisitorial de Álvaro de Montalbán em 1525, cuja filha estava casada com "o Bachiller Rojas que escribió Melibea”. No inventário de livros de Fernando de Rojas, realizado em 1541 após a sua morte, menciona-se um exemplar de El libro de Calisto. Alonso de Proaza, corretor da impressão de 1500 escreve nas suas oitavas ao final da obra "leyendo a Calisto mover los oyentes". Apesar de a obra, no círculo do autor, não ter sido renomeada para La Celestina, o personagem é reconhecido como a intermediária amorosa por antonomásia e hoje encarna o mito da alcoviteira que se apresenta como mestra de se aproveitar das circunstâncias com astúcia.

O sucesso editorial de La Celestina também pode ser comprovado pelas inúmeras reelaborações, reformulações e continuações do personagem Celestina. Baranda Leturio e Vian Herrero (2006:437-440) afirmam que La Celestina é uma obra única cujo sucesso editorial abriu um leque de possibilidades, as quais foram aproveitadas pela indústria livreira. A publicação de outras obras cujas configurações formais e temáticas procuram manter certa coerência espaçotemporal com a obra original se mantém, portanto, dependente de La Celestina ao 
resgatar aspectos físicos e psicológicos dos personagens, reminiscências verbais, gênero, estilo, técnica, tema e argumento. Nas continuações com descendência direta, em geral escritas entre 1534 e 1554, embora reapareçam alguns personagens do modelo ou descendentes deles, se conserve o argumento da conquista de uma donzela pelo discurso persuasivo de uma terceira, imitem episódios e estejam escritas sob a forma de diálogos em prosa com vários atos, cenas e cenários. Nelas, notamos as unidades de tempo e espaço de atuação de cada cenário, em virtude da introdução dos conceitos oriundos do teatro e da arte de representar, posteriores a Fernando de Rojas.

Em 1513 se publica em Logroño Cancionero de Pedro Manuel de Urrea, que inclui a Égloga de la tragicomédia de Calisto y Melibea, adaptação em verso da primeira parte do primeiro ato da obra; o mesmo autor publica em 1517 Penitencia de amor, também inspirada em La Celestina. No mesmo ano, Bartolomé Torres Naharro publica Proppaladia, uma obra dramática cuja Comedia Himenea apresenta clara inspiração celestinesca. Em 1521 as obras Comedia Thebayda, Comedia Hipólita e Comedia Serafina refletem os ecos da obra de Rojas, assim como no ano seguinte, em 1528, a Comedia Tesorina de Jaime de Huete. Nesse mesmo ano Francisco Delicado publica La lozana andaluza, cujos personagens apresentam algumas reformulações do hipotexto. $A$ Tragicomedia de Lisandro y Roselia, a Tragedia Policiana, a Comedia Florinea e Coloquios de amor y bienaventuranza de Juan Sedeño compõem hipotextos da mais famosa das continuações da obra de Rojas escrita por Feliciano de Silva em 1534, a La Segunda Celestina. Uma continuação de La Celestina, conhecida por Tercera parte de la tragicomedia de Celestina é escrita em 1536 por Gaspar Gómez. Em 1612 Alonso Jerónimo de Salas Barbadillo escreve o romance picaresco La hija de Celestina.

Em 1961 é publicada a obra Tiempo de Silencio, escrita pelo espanhol Luis Martín-Santos, na qual temos Celestina dicionarizada: verbo "celestinear" e substantivo "celestineo":

Me gusta y aunque no sé cómo ponerle en el disparadero de su hombria porque no estaría bien, digo yo, celestinear a la nieta en quien ha celestinao a la hija con tanto provecho como yo lo he sabido hacer. Porque esa tonta cuando el bailarín la dejó como la dejó, si no por mí y por mi celestineo, que no me da vergüenza porque al fin y al cabo Dios ha hecho así el mundo, [...] (MARTÍN-SANTOS, 2001, p.63) 
Uma vez se não superados, mas investigados alguns dos ecos literários da obra de Fernando de Rojas que justificam a mudança do título para La Celestina, cabe analisar as estratégias empregadas por Rojas para reinventar a realidade do período de crise e ruptura das estruturas medievais, da gênese da cultura humanista renascentista à Idade Moderna. Consequentemente, investigaremos como o autor transporta sua visão de mundo à realidade ficcional de construção do personagem. Em síntese, analisaremos a verossimilhança interna às leis que regem o texto e as estratégias textual-interativas de construção de sentido do razoamento de Celestina e como ela provoca a adesão dos interlocutores, Pármeno e Sempronio, àquilo que é dito e ocultado pelo personagem, mas presentes no corpus.

A análise das construções verbais e não verbais trabalhadas por Rojas é inicialmente feita à luz da perspectiva semiológica cuja definição de personagem é um signo dentro de um sistema de signos, como uma instância da linguagem ligada à argumentação. Celestina é um personagem que ora se desvela nos microdiálogos e solilóquios, ora se oculta quando revela o seu eu diante do seu outro eu duplo. Ela é um exemplo de experimentação psicológica e moral com a representação dos aspectos anormais do comportamento humano, das paixões limítrofes, como a avareza, a ambição desmedida e a cobiça presentes em todas as suas ações e pensamentos. As estratégias de formulação textual empregadas por ela visam levar os criados, seus interlocutores no corpus, a acreditar em algo ou a agir como ela deseja, o que constantemente é conquistado por meio da sua argumentação persuasiva, que tem caráter dialógico e interacional. Concomitantemente, essas estratégias reforçam a concepção de acordo com a qual a linguagem está intrinsecamente ligada à argumentação, de modo tal que a busca pela persuasão chega a favorecer, no decorrer do texto dialogado, o uso mais frequente de determinadas estruturas linguísticas em detrimento de outras.

As escolhas de Fernando de Rojas ao preferir determinadas estruturas lingüísticas em detrimento de outras levam essa investigação a enfrentar o desafio de analisar como se compõe um texto persuasivo para obter sucesso expressivo. A partir da eleição dos recursos de composição argumentativa, das intenções comunicativas e estratégias de formulação e reformulação textual, tais como o emprego das figuras de estilo — semânticas e sintáticas —, as argumentações se 
baseiam em exemplos bíblicos, em citações de autoridades como Petrarca, Sêneca e Aristóteles, nos recursos retóricos que exploram os ditos, refrães e tópicos literários da época, próprios da cultura humanista de Rojas.

Celestina, já consagrada como excelente enunciadora pelos seus destinatários na obra, fiadora de voz, tom, caráter e corporalidade de sucesso e experiência comprovada e assentida, não obtêm o mesmo sucesso para que seus argumentos convençam seus aliados no seu diálogo final. O movimento na trajetória do personagem equivale a uma coroação seguida do destronamento, polarização semelhante às características encontradas na sátira menipeia, isto é, as imagens da carnavalização são biunívocas porque englobam os dois campos, o da mudança e o da crise, sendo a imagem da morte recriadora e não finita.

A exposição metódica que Celestina faz dos seus objetivos particulares com o intuito de influir nas paixões dos seus destinatários, muito eficaz ao longo dos acontecimentos da trama, não alcança minimizar as distâncias entre seus aliados nos instantes que antecedem a sua morte.

Quais são os elementos situacionais do contexto verbal e não verbal que contribuem para que não seja mais tão eficaz o poder transformador dos atributos do personagem? É o que pretendemos analisar nos capítulos que seguem sobre a construção e a desconstrução do personagem no seu discurso e com a intervenção do discurso do outro.

\section{A proposta}

Esta pesquisa se propõe a analisar as várias indagações sobre como o personagem Celestina se monta de maneira construtiva e desconstrutiva na sua argumentação. A principal premissa afirma que Celestina existe enquanto discurso persuasivo. À medida que seus argumentos não mais persuadem, o personagem perde a função retórica na obra, portanto desconstrói a imagem que construíra de si mesmo através da réplica do outro. Ao desconstruir-se e ser desconstruída pelo outro, falham seus propósitos, resultando na morte do personagem. Consequentemente ocorre o fim da trajetória do amor e se desencadeia o tema da morte como destino punitivo.

Os diferentes graus de persuasão na argumentação de Celestina ao longo dos eventos ou ações se devem ao que Bakhtin classifica como a crise da unicidade do sujeito falante, aquele sujeito que emerge do outro. O sujeito 
bakhtiniano é dialógico e seu conhecimento é fundamentado no discurso que ele produz. Ele atribui ao sujeito um estatuto heterogêneo, isto é, o sujeito modifica seu discurso em função das intervenções dos outros argumentos, sejam eles reais ou imaginados. Portanto, o sujeito não é a fonte primeira e única de sentido, temos de analisar o outro também.

Conforme Bakhtin, "não podemos perceber e estudar o sujeito enquanto tal, como se ele fosse uma coisa, uma vez que ele não pode permanecer sujeito se não tem voz; por conseguinte, seu conhecimento só pode ser dialógico" (Bakhtin, apud Todorov, 1981:34).

A segunda premissa parte do princípio de que persuasão e discurso são elementos teoricamente diferentes, embora na prática funcionem como um todo indivisível. O desfecho do personagem acontece no momento em que Celestina deixa de negociar as distâncias entre os sujeitos, com isso perde a adesão pela qual conseguira alcançar os seus objetivos pessoais e, consequentemente fracassa a negociação, morre o personagem, porém seu discurso e o conteúdo temático persistem.

A última premissa refere-se ao recorte discursivo feito entre os sucessos e fracassos de Celestina, os quais não devem perder de vista as características da literariedade, sobretudo as que implicam a relação entre a maneira de escrever do autor e os códigos de cenografia, caráter e corporalidade do personagem.

Enquanto a imagem de Celestina corresponde à que os demais personagens esperam dela, o raciocínio retórico é eficaz e, assim, as questões "celestinescas" convencem, comovem e agradam. Contudo, no instante em que deixam de aparecer no caráter efetivo de Celestina as propriedades do bom orador: a phrónesis, a eúnoia e o areté — a ponderação, a imagem agradável e a sinceridade -, falham as técnicas argumentativas, acaba-se o diálogo e consequentemente não há mais persuasão.

A desconstrução do personagem ocorre quando a sua imagem efetiva é revelada sob o foco da literariedade, diferente da construída no discurso. Nesse momento, a sensibilidade do seu auditório é ignorada com o aumento da distância em lugar da negociação e com ofensas que não preservam a face do outro. Além de ultrapassar o limite da polidez, as ofensas não resguardam o diálogo, colocando fim à negociação, à argumentação persuasiva, à retórica e ao personagem. Os 
mesmos "outros" que contribuíram para a construção do discurso de Celestina são os que desconstroem o seu espaço de atuação no mundo.

\section{A contribuição}

Uma das dificuldades com que se depara uma monografia que investiga as características de um personagem construído discursivamente é a de incorrer no campo da subjetividade por ser intuitiva. A ideia de que, ao argumentar, Celestina ativa nos demais personagens determinada representação de si mesma, não subestima o fato de que seus interesses são essencialmente práticos. Entretanto, para a identificação do éthos do personagem são acionadas estratégias de proteção e não um conceito teórico claro. Nessas condições, devemos inscrevê-la em uma problemática precisa, a de como se realizam os sucessos e fracassos argumentativos do personagem, privilegiando a faceta específica da literariedade, em função, ao mesmo tempo, do corpus proposto, dos objetivos gerais e específicos da pesquisa e do interior da disciplina em que se insere a pesquisa: a literatura espanhola de transição dos valores medievais à gênese do humanismo, da Renascença à Idade Moderna.

A análise do discurso que articula a representação da cenografia e a incorporação textual não pode apreender o éthos da mesma maneira que a teoria da argumentação e a análise do discurso inspirada na retórica do discurso. Portanto, para a análise pragmática da argumentação persuasiva de Celestina à luz das características gerais do personagem, da obra, do autor e do contexto sóciocultural e histórico serão entrelaçadas as bases teóricas das áreas de conhecimento da teoria da argumentação, do personagem de ficção, da literariedade e da história social do período.

\section{A organização}

Esta pesquisa tem objetivos gerais que abrangem a imagem de si mesmo construída pelo personagem no discurso - o éthos efetivo e projetivo - o caráter propriamente dito do discurso - o $\log o s-\mathrm{e}$ as paixões que Celestina suscita nos demais personagens - o pathos.

Para o cumprimento dos objetivos gerais adotamos a definição dos termos éthos efetivo e éthos projetivo empregada por Michel Meyer (2007) em $A$ 
retórica. Ao pretender resolver suas questões com os seus destinatários Sempronio e Pármeno - Celestina, como perspicaz enunciadora, revela dois éthos jogando com os valores dos criados para apresentar uma resposta ao problema. O primeiro, o éthos efetivo, é aquele por meio do qual a enunciadora, em sua ação real, se esforça para responder às questões, sem levar forçosamente em consideração a distância de valores dos destinatários; o segundo, o projetivo ou imanente, é aquilo que o outro da relação retórica projeta como imagem, isto é, a visão imanente como imagem que Celestina reflete sobre o seu auditório. Tanto Celestina quanto seus destinatários projetam no outro uma imagem que, necessariamente, não corresponde à realidade. Celestina projeta a imagem de uma enunciadora confiável e experiente e os criados, de destinatários que aderiram ao objetivo pessoal dela.

Os objetivos específicos abrangem os procedimentos argumentativos no discurso persuasivo e as ações para alcançá-los, uma vez que Celestina se define com mais nitidez na distensão temporal dos eventos ou das ações. Como o seu discurso apresenta o movimento que oscila do auge ao descenso argumentativo é foco dos objetivos específicos desta pesquisa identificar e percorrer o caminho de desconstrução do discurso do personagem ao longo da trama.

No primeiro capítulo, esta pesquisa investiga os objetivos gerais que caracterizam dialética, estética e eticamente o personagem.

1. Objetivos gerais:

1.1. Especificamos qual é o objetivo defendido por Celestina, que argumentos a sustentam, legitimam e viabilizam e quais são refutados à luz da dimensão dialética.

1.2. Sob a ótica da dimensão estética, investigamos e refletimos sobre os recursos expressivos e as estratégias utilizadas pelo personagem para sensibilizar e atrair seu auditório e, consequentemente, alcançar a adesão para os seus interesses.

1.3. Em função da dimensão ética, explanamos sobre como Celestina constitui legitimidade e credibilidade como enunciadora para conquistar a confiança dos demais personagens. 
No segundo capítulo, esta investigação elenca e reflete os objetivos específicos que levam à construção do discurso de Celestina.

2. Objetivos específicos:

2.1. Em função das dimensões dialética, estética e ética explanamos sobre o processo transcorrido pelas estratégias persuasivas nas várias tentativas com o Pármeno para atraí-lo a seu favor: a invocação ao passado de sua mãe, a amizade com Sempronio, o apelo à cobiça do dinheiro de Calisto, e o apelo à luxúria com a tática de sedução de Areúsa que culmina com um encontro amoroso.

2.2. Partimos para a análise do primeiro texto do corpus para estudar o processo de construção do personagem no seu discurso persuasivo em uma das tentativas com Pármeno. Durante o estudo desse processo consultamos uma das fontes literárias de Fernando de Rojas, a segunda carta de Sêneca a Lucílio sobre a diversidade na leitura.

No terceiro capítulo, esta pesquisa investiga os motivos pelos quais o discurso de Celestina sofre a desconstrução através da interpelação do discurso do outro.

3.1. Ao analisar o segundo texto do corpus, fazemos uma reflexão sobre os argumentos de Celestina com Sempronio e Pármeno que culmina com a morte do personagem.

3.2. Respondemos aos questionamentos levantados e considerações finais. 


\section{O PERSONAGEM CELESTINA}

Si no voy, ¿qué dirá Sempronio? ¿Qué todas éstas eran mis fuerças, saber y esfuerço, ardid y ofrecimiento, astucia y solicitud? Y su amo Calisto, ¿Qué dirá, qué hará, qué pensará sino que ay nuevo engaño en mis pisadas y que yo he descubierto la celada por haver más provecho desta otra parte, como sofistica prevaricadora? $O$, si no se le ofrece pensamiento tan odioso, dará bozes como loco. Diráme en mi cara denuestos rabioso; proporná mill inconvenientes que mi deliberación prestale puso, diciendo: "tú, puta vieja, ¿por qué acrecentaste mis pasiones con tus promessas? ;Alcahueta falsa, para todo el mundo tienes pies, para mí lengua; para todos obra, para mí, palabras; para todos remedio, para mí, pena; para todos esfuerço, para mí, falta; para todos luz, para mí, tiniebla! Pues, vieja traydora, ¿por qué te me ofreciste? Que tu ofrecimiento me puso esperança, la esperança dilató mi muerte, sostuvo mi vivir, púsome título de hombre alegre. Pero no haviendo efeto, ni tú carecerás de pena ni yo de triste desesperación." Pues, ;triste yo! ¡Mal acá, mal acullá, pena en ambas partes! Quando a los estremos falta el medio, arrimarse el hombre al más sano es discreción. (IV, Cena 1, pp. 208-209)

A consciência desintegrada de Celestina a caminho da casa de Melibea. 


\section{Introdução}

Neste capítulo investigamos não só como Celestina é construída à luz das ciências da linguagem, mas também como o personagem pode ser visto sob os focos da história social, da história da literatura espanhola e das potencialidades e restrições do autor, fruto de uma Espanha do fim do século XV. Dessas interfaces surgem alguns ângulos de interpretação de um leitor contemporâneo, os quais podem ou não se aproximar dos pontos de vista do autor. Da mesma maneira que nos voltamos para o que o passado considerou literatura para confrontarmos a perspectiva presente com as anteriores, os modos de produção de sentido do presente interrogam os do passado. O contexto histórico e a formação social de $L a$ Celestina, colocados em contato com os nossos e os de todos os tempos, proporcionam várias leituras. Essa rica possibilidade de interpretação se dá exatamente porque as limitações e habilidades que o autor confere ao personagem aparecem na leitura do seu processo de construção articuladas pelas susceptibilidades de cada leitor. Por essa razão, discorremos neste capítulo sobre o tema do personagem como construção, sob o âmbito da história social da Espanha em transição para o Renascimento e enfocado por Fernando de Rojas ${ }^{8}$, que escreve um texto dinamicamente dialogado.

Sem recorrer neste momento às questões sobre o gênero literário de $L a$ Celestina, concordamos que em razão da contundente presença do diálogo dinâmico na obra nos vimos diante da necessidade de esclarecer alguns aspectos sobre a terminologia que adotamos na nossa investigação em função dos teóricos consultados. À luz das ciências da linguagem, reconhecemos Celestina como enunciadora e ao analisar a construção de um personagem no seu discurso contamos com que, por sua vez, esse discurso pressuponha a construção de uma imagem daqueles que estão envolvidos no processo interativo. Nesse processo, classificamos Celestina como enunciadora de um discurso persuasivo embasado na perspectiva de Maingueneau (2001) que a coloca como aquela a quem se outorga no discurso uma posição institucional que marca sua relação com o saber.

${ }^{8}$ Não é nosso propósito investigar as questões sobre a autoria de La Celestina. Fernando de Rojas certamente é "o" ou "um" dos autores. 
Portanto, investigaremos neste capítulo como a relação de Celestina com o saber advém das limitações e habilidades psicológicas, físicas, histórico-sociais e discursivas que o autor lhe conferiu.

No quadro da teoria da enunciação, nascida dos trabalhos de E. Benveniste e desenvolvida por J. C. Anscombre, O. Ducrot e, mais recentemente, C. KerbratOrecchioni, o termo enunciador designa o sujeito que realiza um ato de enunciação ou enunciado. O enunciador é assim o sujeito empírico que, ao proferir a palavra "eu", implanta um "tu" diante de si, ao mesmo tempo que "eu" e "tu" se inscrevem imediatamente em determinado tempo e espaço, produzindo um enunciado que é sempre irrepetível e historicamente assinalado. Em consequência, verificamos a necessidade de que a análise da construção do personagem seja feita sob os olhares da história social e da literatura dentro das limitações e habilidades de Fernando de Rojas, um judeu converso com pouco mais de vinte anos, estudante de Direito na já urbana Salamanca.

O. Ducrot (1987) abrange o conceito de enunciador e seu diálogo com a história sob os holofotes da teoria polifônica. Nesse enfoque, o enunciador pressupõe um ou mais destinatários, entidades situadas em um segundo nível de polifonia. $\mathrm{O}$ enunciador é, segundo o autor, uma entidade responsável por certo ato de fala a quem o locutor imagina que se dirige. Por essa razão, para analisar a construção de um personagem em um processo discursivo, precisamos reconhecer e analisar devidamente quem são seus destinatários porque, em La Celestina, serão eles quem intervirão para desqualificar ou desconstruir a enunciadora no processo discursivo.

Para adotar uma terminologia adequada a nossa pesquisa, verificamos que o termo coenunciador foi introduzido pela linguística enunciativa por Culioli como um termo correlativo ao de destinatário que, por sua vez, acentua a ideia de que a enunciação é um processo no qual dois ou mais participantes desempenham um papel ativo. A alternância de posição entre ouvinte e locutor faz com que ambos participem de maneira dinâmica do processo enunciativo. Enquanto a Análise do Discurso utiliza as terminologias enunciador e coenunciador, a Retórica fala em locutor e receptor: o locutor designa a pessoa que fala, aquela que emite uma mensagem no ato da comunicação efetiva e o receptor, a quem ela se destina. Da mesma forma, para Charaudeau \& Maingueneau (2004:311), o locutor é o sujeito falante responsável pelo ato de linguagem em oposição ao 
sujeito que acolhe o ato de linguagem que pode ser designado nos termos de interlocutor, receptor ou alocutário. Para os estudos retóricos, utiliza-se o termo orador como locutor e auditório como receptor. Contudo, no âmbito da nossa investigação adotaremos os termos enunciador e destinatário.

Sempronio, Pármeno, Melibea e Calisto são, portanto, os mais frequentes e principais coenunciadores ou destinatários de Celestina porque são a quem ela, na posição de enunciadora, dirige o seu discurso e juntos exercem um papel ativo no processo discursivo. Ela melhor se constrói como persuasiva enunciadora em função do discurso desses destinatários.

Celestina - do latim Caelestis, a que descende do céu, a angelical, mais o sufixo "ina”, que é um diminutivo com valor pejorativo; ou ainda scelere, também do latim, trair ou fazer maldade - reforçam a intenção irônica de Rojas, além de produzir efeitos de sentidos que variam do cômico ao trágico: desencaminha donzelas do seu destino matrimonial naquela sociedade para depois acabar com a motivação de romper com as regras sociais, escraviza as prostitutas a servir aos criados que morrem vergonhosamente, arruína o nobre sem-futuro acabando com a sua honra, seu corpo e fortuna e destrói o sonho de continuidade dos recentes burgueses.

\section{Celestina - uma leitura do personagem}

No momento em que um personagem é criado pelo autor são definidas as suas características. Essas escolhas incidem nas suas habilidades e limitações e, desse modo, o autor compreende que o texto será estruturado em torno dessas características, além de que deverá desenvolver a história considerando essas possibilidades. Por exemplo, se um personagem não tem poderes de feitiçaria, o autor supõe que não poderá fazer um conjuro a Plutão, como o faz Celestina, a menos que, no desenlace do texto, surja alguma fórmula que lhe dê esse poder. Isso seria coerente no contexto. $\mathrm{O}$ autor sabe das habilidades e limitações de seu personagem, por isso deverá direcionar o texto de acordo com as suas possibilidades, entretanto, quando não mais o fizer, a trajetória de vida ficcional pode acabar para seu personagem. O que impossibilitou de Celestina negociar a distância entre seus interlocutores? Uma das suas limitações: a avareza.

As habilidades e limitações são os pontos de partida para a construção de Celestina, nem sempre conhecidos pelos leitores, ora por serem ocultados pelo 
autor, ora por não terem sido desvelados pelos personagens. Quem poderia imaginar que Celestina temeria fracassar com Melibea, personagem autenticamente humano que apresenta sentimentos como a dúvida, o medo, o amor, repleta de conflitos interiores? Essas limitações podem estar por trás da origem conversa do autor e do pessimismo existencial - o amor é enganoso, a morte é real - gerado pelo isolamento e a solidão do indivíduo na estratificada sociedade de transição para o Renascimento. Essas habilidades estão na verossimilhança e na autonomia dos personagens apoiados nas características estoicismo, epicurismo, hedonismo e niilismo - dos seres ficcionais femininos que, emergidos daquela sociedade urbana sob as influências da cultura humanista e de outras correntes refletidas na obra, são matizes individualizadores para elementos temáticos.

As pessoas reais ${ }^{9}$ são "unidades concretas, integradas de uma infinidade de predicados", ao passo que nossa percepção de realidade é "extremamente fragmentária e limitada". Em uma obra ficcional, o número de orações encontradas no texto é muito mais limitado do que seria no mundo real e, por isso, pode-se imaginar que nossa percepção do personagem tenderia a ser mais fragmentária, o que, notavelmente, não ocorre em La Celestina, pois, sendo finito o texto de uma obra ficcional, o personagem construído pelo autor torna-se "uma configuração esquemática" em todos os sentidos: físicos, intelectuais, emocionais e psicológicos. Contudo, a limitação do texto proporciona "zonas indeterminadas" no discurso, regiões de ambiguidades e indeterminação que serão preenchidas na mente dos leitores ou espectadores (ROSENFELD, 1987, pp. 32-33). A respeito dessas zonas, ainda Rosenfeld (1987:33) argumenta que:

Este fato das zonas indeterminadas do texto possibilita até certo ponto a "vida" da obra literária, a variedade das concretizações, assim como a função do diretor de teatro, chamado a preencher as múltiplas indeterminações de um texto dramático. Isso, porém, se deve à variedade dos leitores, através dos tempos, não à variabilidade da obra, cujos personagens não têm a mutabilidade e a infinitude das determinações de seres humanos reais. As concretizações podem variar, mas a obra como tal não muda.

Contribui para enriquecer as regiões de ambiguidades e "zonas indeterminadas" o fato de que La Celestina é uma obra predominantemente

\footnotetext{
${ }^{9}$ Expressão utilizada por Anatol Rosenfeld em seu artigo Literatura e personagem para
} relacionar e comparar personagens ficcionais com pessoas reais. 
dialogada sem a intervenção de um narrador para descrever com mais precisão os estados de espírito e as reações físicas dos personagens, de maneira que promova uma percepção mais contínua do enredo. Sem dúvida é desnecessária a presença de um narrador nessa obra, cujo texto é desvelado pelo diálogo dinâmico entre os personagens, que transforma "os aspectos esquematizados pelas orações em plena concreção" (ROSENFELD, 1987, p. 33), as referências discursivas em ações visuais, o discurso descontínuo do diálogo em um discurso visual-auditivo contínuo. Isso, no entanto, não elimina as zonas indeterminadas na interpretação do leitor. Rosenfeld (1987:34) explica como ocorre a percepção do leitor nessas zonas:

O curioso é que o leitor ou espectador não nota as zonas indeterminadas (que também no filme são múltiplas). Antes de tudo porque se atém ao que é positivamente dado e que, precisamente por isso, encobre as zonas indeterminadas; depois, porque tende a atualizar certos esquemas preparados; finalmente, porque costuma "ultrapassar" o que é dado no texto, embora geralmente guiado por ele.

Assim, "a limitação da obra ficcional é sua maior conquista", pois o limitado número de orações no texto faz com que os personagens adquiram "um cunho definido e definitivo que a observação das pessoas reais, e mesmo o convívio com elas, dificilmente nos pode proporcionar a tal ponto".

Rosenfeld acredita que "a ficção é o único lugar - em termos epistemológicos - em que os seres humanos se tornam transparentes à nossa visão", exatamente por serem seres "totalmente projetados pelas orações" (ROSENFELD, 1987, pp. 34-35). Os seres humanos estão refletidos em ficcionais em La Celestina através do diálogo, dos microdiálogos, das réplicas, dos solilóquios dos próprios personagens. Sobre a presença do diálogo na obra ficcional Rosenfeld (1937: 29-30) afirma que:

\footnotetext{
Não são mais as palavras que constituem os personagens e seu ambiente. São os personagens (e o mundo fictício da cena) que "absorveram" as palavras do texto e passam a constituí-las, tornando-se a fonte delas - exatamente como ocorre na realidade. (...) o diálogo é concebido de dentro dos personagens, tornando-as transparentes em alto grau.
}

O texto dialogado necessita da voz e da corporalidade do personagem para que este dê vida às palavras e transforme as mesmas em discurso visual auditivo. $\mathrm{Na}$ passagem do texto para o discurso, a obra dialogada é encarnada pela 
corporalidade do personagem em cena. Como La Celestina ainda não é uma obra teatral, embora apresente muitas das características dramatúrgicas que surgiram anos depois, podemos visualizar os traços físicos dos personagens e dos espaços percorridos por eles.

As habilidades e limitações de Celestina fazem dela um personagem verossímil, fruto da transição para a Idade Moderna na Espanha em que prostitutas, feiticeiras, alcoviteiras, charlatãs e mais todos os seus ofícios eram requisitados pelos nobres, pelos criados e pela nova classe social que surgia, a burguesia.

Jean-Pierre Ryngaert (1996:19-25) ressalta que os personagens, quando ainda se encontram no plano textual, possuem inúmeras interpretações possíveis e que, ao serem transportados para o plano físico, passam por um filtro que envolve múltiplas escolhas e renúncias:

\begin{abstract}
Nenhuma encenação, por mais bem-sucedida que seja, esgota o texto, e não é raro encontrarmos atores que preferem os ensaios à representação, como se esta última implicasse a perda de toda a gama de possíveis. Um diretor de teatro abandona direções na medida em que as escolhe. Precisa renunciar a pistas encontradas durante o trabalho, fechar canteiros de obras por muito tempo abertos, renunciar a filões que o levam para muito longe de suas bases. (...) Um bom texto de teatro é formidável potencial de representação. Esse potencial existe independentemente da representação e antes dela. Portanto, esta não vem completar o que estava incompleto, tornar inteligível o que não era. Trata-se antes de uma operação de outra ordem, de um salto radical numa dimensão artística diferente, que por vezes ilumina o texto com uma nova luz, por vezes o amputa ou o encerra cruelmente. (RYNGAERT, 1996, pp. 22-25)
\end{abstract}

La Celestina foi escrita para ser lida diante de um pequeno público ${ }^{10}$ inicialmente como uma prática universitária e posteriormente se amplia para os leitores da incipiente Idade Moderna-, distintamente de uma representação teatral, o que nos leva a concluir que o processo de leitura de um texto dialogado é a projeção preponderantemente intelectual deste. Torna-se possível conceituar, por um lado, como atividade de leitura de um personagem, as escolhas e renúncias em face da grande variedade de hipóteses interpretativas lançadas pelo texto, bem como o preenchimento das zonas indeterminadas suscitadas pelo seu conteúdo.

\footnotetext{
${ }^{10}$ Rojas referenda no Prólogo que La Celestina foi escrita para ser lida em voz alta e não
} representada diante de um auditório reduzido: “Assí que, quando diez personas se juntaren a oýr esta comedia, en quien quepa esta differencia de condiciones, como suele acaescer, ¿quién negará que aya contienda em cosa que de tantas maneras se entienda?" (p. 107). 
Por outro lado, quando se fala da construção de um personagem, está-se referindo ao processo por meio do qual o autor transforma em personagem uma configuração esquemática previamente definida. Ambos os procedimentos são criações e ambos possuem limitações. A definição é a limitação da construção, a construção é a concreção de uma definição possível e a limitação da definição é o próprio texto. Com base neste conceito de "construção", a análise da desconstrução será o processo pelo qual Rojas escolhe desarmar, destruir, desfazer da criação da personagem no seu discurso sob a influência do discurso do outro.

Portanto, as múltiplas escolhas e renúncias de Fernando de Rojas ao criar Celestina se devem às limitações impostas pelo próprio texto. Cria uma Celestina velha e experiente, gananciosa, avarenta, com retórica cicatriz no rosto. Sobre essa marca logocêntrica Soto Ribera afirma:

La Celestina es una prosopopeya de la retórica. Y un indicio, hallado por nosotros, de que con Celestina tratamos con una prosopopeya de la retórica es su cicatriz en la cara. Pleberio le reprocha al Amor: "Ni sé si hieres con hierro ni si quemas con fuego" (21.603). La alcahueta Celestina sí sabe que el Amor hiere con hierro y quema con fuego.

Reconhecida por todos pelos seus feitos passados de curandeirismo, mediação amorosa, prostituição e feitiçaria. Um personagem que ora sente medo de não conseguir persuadir Melibea a receber Calisto, ora sente confiança em convencer Pármeno a ser seu aliado. Celestina mente sobre o paradeiro da corrente de ouro, fruto do pagamento pelo seu negócio com Calisto, mente sempre e quando é necessário e diz a verdade quando não vê razão em dividir o ganho com os criados porque acredita que eles não fizeram nada para merecê-lo. Cria um personagem que, se observada como uma crítica estoica à condição humana, diante de uma leitura existencialista, exorta o carpe diem e morre; sob uma leitura didata-moralizante, comete seus pecados e é punida com a morte, à luz da história social, é produto de um descendente de conversos, fruto da tragédia do povo judeu espanhol.

O personagem Celestina surge no enredo pelas artimanhas de Sempronio, um criado com características semelhantes a dos pícaros da literatura espanhola do século XVII: infiel, ciumento, rancoroso, hipócrita, covarde e violento. Após a rejeição de Melibea diante da declaração amorosa de Calisto, os criados são os 
que interagem diante dos desvarios do amo. Sempronio, depois de longa argumentação misógina em oposição à divinização de Melibea por Calisto, decide ajudá-lo com a amada. O criado, infiel, lhe propõe a mediação de Celestina, com intenções de fazer uma sociedade com a intermediária amorosa; para isso recebe então, como reconhecimento pela imagem de criado devoto ao amo, uma roupa como prêmio.

Sempronio: “[...] Gentiles, judíos, christianos y moros, todos em esta concordia están. Pero lo dicho y lo que ellas dixiere, no te contezca error de tomarlo en común, que muchas hovo y ay sanctas y virtuosas y notables cuya resplandescenciente corona quita el general vituperio. Pero destas otras, ¿quién te contaría sus mentiras, sus trafagos, sus cambios, su liviandad, sus lagrimillas, sus alteraciones, sus osadías, que todo lo que piensan osan sin deliberar, sus discriminaciones, su lengua, su engaño, su olvido, su desamor, su ingratitud, su inconstancia, su testimoniar, su negar, su rebolver, su presunción, su vanagloria, su abatimiento, su locura, su desdén, su sobervia, su subjeción, su parlería, su golosina, su luxuria y suziedad, su miedo, su atrevimiento, sus hechizerías, sus embaimientos, sus escarnios, se deslenguamiento, su desverguença, su alcahuetería?" (Ato I, Cena 4, p.131)

No razoamento de Sempronio sobre o que os clássicos como Salomão, Aristóteles e Sêneca opinam sobre as mulheres temos claramente o anúncio de como Celestina será reconhecida, não só à luz da confluência das três religiões “gentiles, judíos, christianos y moros, todos en esta concordia están. Pero lo dicho y lo que ellas dixiere, no te contezca error de tomarlo en común" - , mas sob o foco dos sentimentos baixos e das ações negativas. Ressaltamos neste diálogo a menção do que se encaixa nas características da velha alcoviteira entre a descrição das mulheres que "contariam coisas sobre sua língua, seus enganos, sua presunção, sua luxúria e sujeira, seu medo, seu atrevimento, sua feitiçaria, sua falta de vergonha, sua alcoviteirice". Rojas desvela nesse momento, ainda de forma indireta, o personagem Celestina através da voz de Sempronio: uma mulher que sobrevive das baixas paixões e da miséria moral da sociedade e que intermediará o encontro de Calisto com sua amada.

O leitor conhece Celestina através da leitura estereotipada com pesada carga simbólica pela voz do criado. A primeira característica metaforicamente mencionada por Sempronio foi "barbuda", aspecto físico tipicamente masculino, o que nos remete à velhice, luxúria e poderes demoníacos: "sagaz en quantas maldades ay". Para que o criado convença Calisto a aceitar Celestina como mediadora com a função de diminuar a sua rejeição diante de Melibea, Sempronio afirma que a velha é uma autoridade na cidade em razão de seus poderes - 
ratificado pela marca logocêntrica da cicatriz no rosto que, por si só, já é um forte indício de que seu discurso seja eficaz como a sua língua, afiada.

Sempronio: "_ [...] días ha grandes que conozco, en fin desta vezindad, una vieja barbuda que se dize Celestina, hechizera, astuta, sagaz en quantas maldades ay. Entiendo que passan de cinco mill virgos los que se han hecho y desecho por su autoridad en esta cibdad. A las duras peñas promoverá y provocará a luxuria si quiere." (Ato I, cena 4: 139)

Como Sempronio é o personagem que melhor conhece Celestina porque tem uma visão de mundo parecida com a dela, exalta suas qualidades quando é necessário e revela seus defeitos quando se vê traído por ela. Se, por um lado, a apresentação que o criado faz da velha ao seu amo revela intencionalmente ao leitor mais um dos principais traços psicológicos apreciativos da velha: a luxúria; por outro, na eminência da morte de Celestina, faz novas revelações depreciativas do criado como a cobiça ${ }^{11}$ e a avareza:

Sempronio: "_ [...] No es esta la primera vez que yo he dicho quánto en los viejos reyna este vicio de cobdicia; quando pobre, franca; quando rica, avarienta. Assí que, adquiriendo cresce la cobdicia y la pobreza cobdiciando, y ninguna cosa haze pobre al avariento sino la riqueza" (XII, Cena 10, p. 387)

\section{Celestina à luz da história social}

Sob a perspectiva histórica em que Celestina é construída, em meio a importantes fatos que permeiam a obra, as influências que o autor sofre para criar as limitações e habilidades do personagem dão um efeito de sentido verossímil ao personagem. A investigação levará à proposição de que na mesma medida em que o autor espelha os conflitos entre o amor e a fortuna sobre o indivíduo e seu mundo, a história social interfere na condição humana.

A Península Ibérica passava por profundas mudanças sócio-políticas, econômicas e culturais entre 1474 e 1541, período que inclui a formação do autor Fernando de Rojas. Nos reinos da Península Ibérica a população era essencialmente rural, mais da metade pertencia à classe produtora composta de lavradores, embora $18 \%$ do total fossem notários, profissionais liberais,

${ }^{11}$ A palabra cobiça é originária do latim cupiditia ou cupiditas - desejo ávido, ansioso, apaixonado; ambição, avareza, faccionalismo, espírito de festa - tem a ver com "cupido", o deus do amor que significa: desejo por poder, ambição, além de desejo físico. Cupidus era o termo em latim empregado para quem praticava o "cupido", que se aproxima da alcoviteira. 
funcionários públicos, mercadores, comerciantes e artesãos que já moravam nos pequenos centros urbanos juntamente com a incipiente classe média composta de fidalgos (9\%), espaço social de La Celestina. A minoria que não pagava impostos pertencia à aristocracia e ao clero.

O Reino de Castela em 1474, após a morte de Henrique IV, o Impotente (1454-1474), passava por uma aguda crise de todos os níveis: social, econômico e político, empobrecida com o encarecimento do custo de vida e com problemas sociais gerados pela convivência muitas vezes conflitiva entre cristãos, judeus conversos e muçulmanos.

Principalmente nas áreas urbanas mais importantes do Reino de Aragão já havia grandes populações de judeus em guetos e uma longa tradição da sua influência e ocupação em postos religiosos e políticos de importância desse Reino; um exemplo disso foi o de João II, pai de Fernando II (1452-1516) de Aragão, ter indicado o judeu Abiathar Crescas como astrólogo da corte.

Fernando II de Aragão, o Católico, instala a princípio uma Inquisição local na sua confederação para atingir judeus e muçulmanos que impunham sua presença indesejada ocultada pela motivação econômica: como muitos financistas judeus forneceram o dinheiro que Fernando II usou para casar com Isabel, a rainha de Castela, vários desses débitos seriam extintos se o financiador fosse condenado pela Inquisição.

Apesar de o papa Sixto IV ser contra por causa dos abusos, em 1478 se instala a Inquisição em Espanha, até 1834. Fernando II de Aragão e Isabel de Castela (1451 - 1504) nomeiam, em 1481, Tomás de Torquemada (1420-1498) como Inquisidor-Geral para investigar e punir os conversos na tentativa de impor o cristianismo concluindo assim a Reconquista. Este foi responsável por muitos autos de fé até sua morte em 1498, incluindo o seu apoio no Decreto de Alhambra que culminou com a expulsão dos judeus da Espanha em 1492. Os espanhois tomam Granada, o último reduto árabe na Península, impondo sua presença, sua cultura, sua língua e dão início a um Estado moderno e imperial.

Diante do histórico de perseguição aos judeus, que se não se convertessem eram expulsos, possivelmente Fernando de Rojas recorreu ao tópico literário da autoria compartilhada ou do anonimato. Trata-se de uma característica das comédias humanísticas utilizada como técnica narrativa e recurso para esconderse da censura, salvaguardar o nome do autor e mover-se livremente pela ficção 
diante da Inquisição instaurada na Península Ibérica, uma vez que Rojas, apesar de integrar-se socialmente, ser Bacharel em Leis pela Universidade de Salamanca e da sua situação de fidalguia, tem à sombra suas origens conversas.

Os escritores do período de Rojas retomam os temas, as formas, os gêneros e os registros literários comúns nos modelos italianizantes da tradição clássica greco-latina como as comédias latinas, elegíacas e humanísticas. Estes modelos ressurgem na literatura pelas mãos da alta nobreza e dos letrados, professores, secretários constituintes da elite cultural do século XV na Península Ibérica, como Pero López de Ayala, Íñigo López de Mendoza, Marqués de Santillana, Juan de Lucena, Juan de Mena, Alonso de Cartagena, Alonso de Palencia, Fernán Pérez de Guzmán, Elio Antonio de Nebrija. Parte dessa elite cultural é fruto da Universidade de Salamanca, criada em 1218 por Alfonso IX de Leão, a qual se torna no fím do século XV um dos centros acadêmicos mais importantes e prestigiados da Europa, pois, além de prover a administração imperial com letrados, foi centro de pesquisas para matemáticos, juristas, linguistas, economistas entre outros.

Com fortes influências sobre a história da humanidade e sensivelmente na literatura, também em 1492, Cristovão Colombo chega a América e, com a intervenção do papa valenciano Alexandre VI e por meio do Tratado de Tordesilhas, em 1494, divide entre Portugal e Castela as esferas de influência no Novo Mundo. Essa divisão impulsionou a mudança da percepção do homem europeu sobre seu entorno e deu uma nova dimensão dentro da sociedade europeia com a perspectiva de fazer fortuna e ou viver uma vocação evangelizadora na América. Contudo, essas grandes navegações portuguesas e espanholas, que proporcionaram a expansão marítimo-comercial daqueles Reinos — embora diferentes quanto às consequencias: as navegações portuguesas contribuíram para formar a classe burguesa e as espanholas, enriqueceram a monarquia —, não somente contribuíram para enriquecer a Coroa espanhola com a compra de armas para conquistar mais territórios, mas principalmente para formar a nova classe social em Portugal, a burguesia, e ampliar a visão de mundo com a descoberta das Índias por Vasco da Gama, em 1497. Nesse sentido, a sensibilidade do humanista Fernando de Rojas transparece na obra sob a forma de uma crítica aos valores renascentistas e a adesão ao projeto nacional imposto pelos Reis católicos de Castela. 
Elio Antonio de Nebrija (1444-1522), professor de gramática na Universidade de Salamanca em 1473 e na Universidade de Alcalá em 1490, escreve em 1492 a primeira gramática da língua castelhana e os primeiros dicionários latim-espanhol e, três anos mais tarde, espanhol-latim reforçando a tese de que a língua é um instrumento de poder do Império.

Em 1495, o Cardeal Gonzalo Jiménez de Cisneros (1416-1517), confessor e conselheiro da rainha Isabel I de Castela, como arcebispo de Toledo, inicia a reforma das ordens religiosas e contribui para a fundação do ColégioUniversidade Complutense em 1499 em Alcalá de Henares, a primeira universidade renascentista, moderada, humanista e universal composta pelos melhores mestres.

Em 1497, morre aos dezenove anos o herdeiro dom João de Trastâmara, príncipe das Astúrias e de Girona, único filho homem dos Reis Católicos, casado com Margarida de Habsburgo, arquiduquesa da Áustria.

Em 1500, nasce Carlos, futuro imperador Carlos I e V da Alemanha, filho de Joana, a Louca, filha dos Reis Católicos, com Felipe de Habsburgo, o Hermoso. Um ano depois começam os autos de fé em Toledo, nos quais se decreta a conversão forçosa dos mouros granadinos sob pena de expulsão.

Com a morte de Fernando II de Aragão ou V de Castela, o Cardeal Cisneros é nomeado regente até que Carlos I de Espanha possa ser coroado como Imperador do Sacro Império (como Carlos V); rei de Aragão a partir de 1516; regente de Castela em nome da mãe entre 1516 e 1555 e rei de jure entre 1555 e 1556, unifica as duas coroas e torna-se o primeiro rei de Espanha (1555-1556), parte desse período posterior à morte de Fernando de Rojas em 1541.

\section{O sentido literário em La Celestina - os temas celestinescos}

Estudaremos quais são os traços que fazem de La Celestina uma obra literária em que reconhecemos os temas celestinescos. Certamente, seu sentido literário está presente na propriedade universal (EIKHENBAUM, B. et alii, 1976, p. 27) que estabelece as fronteiras do literário e nos traços que a fazem construir uma realidade autônoma. 
A primeira grande questão que levantamos à luz da literariedade é o surgimento do tema especificamente "celestinesco" entre as bases literárias de $L a$ Celestina que, sob a inspiração do pensamento humanista de Petrarca entre outros, sofre profundas influências da problemática conversa do autor e seu enfrentamento com o ambiente social. A obra marcou a literatura universal criando o mito da alcoviteira que se presta a persuadir em causa própria. O tema celestinesco segundo Villanueva (1993:16) vai além do motivo em que a terceira, a mediadora amorosa, se apresenta à sociedade para seduzir por interesse material uma mulher honesta dentro de sua própria casa. Está na principal causa da necessidade da mediadora: nas relações amorosas entre conversos e cristãos velhos. A convivência conflituosa na Península Ibérica entre as três religiões: o cristianismo, o judaísmo e o islamismo, sobretudo no período da nossa investigação — na Baixa Idade Média ou nos últimos anos de crise do feudalismo em direção a um ideal humanista - é o reflexo da transição entre Oriente e Ocidente, entre o passado medieval e a transição para a modernidade.

Efetivamente, o tema celestinesco não se resume à alcoviteirice, mas envolve uma gama de abordagens que abrangem questões sociais e econômicas. Villanueva (1993:114) afirma que:

[...] en la Península Ibérica la alcahuetería no dejaba de ser igualmente una seria preocupación colectiva durante la Edad Media y comienzos de los tiempos modernos. [...] el proxenetismo salta a la vista como uno de los crímenes más odiosos en la legislación medieval española. En cuanto a los fueros de los siglos XI y XII permiten un atisbo de la naciente vida urbana y de sus diarias realidades, el delito de alcahutería se perfila obsesivo y aparece siempre castigado con las más severas penas. Los alcahuetes son declarados infames, hasta el punto de que el simple envío de una proxeneta a una mujer honrada contituye en sí un acto injurioso.

As questões sociais e econômicas envolvidas com o tema celestinesco nos levam não somente a considerar como aspecto extratextual a intermediação amorosa - uma vez que era prática "comum"12 nas cidades espanholas do final do século $\mathrm{XV}$, período de transição entre os últimos anos da crise do feudalismo e das estruturas medievais, mais especialmente ao que corresponde a La Celestina, que teria sido escrita por volta de 1498 — , mas também a reconhecer que a

12 De cantigas de amigo galego-portuguesas a cantigas orientais se apresentavam personagens com as características de uma alcoviteira. 
extratextualidade proporciona, independentemente da distância temporal e espacial $^{13}$, as diversas leituras através da continuidade cultural.

Um aspecto extratextual inerente à obra é a referência indireta às vivências reais do autor, um jovem solteiro, estudante de direito na Salamanca de 1499, entre 23 e 25 anos. Podemos associar alguns acontecimentos da época à obra levando em consideração o que Anatol Rosenfeld (2004:18 e 19) ${ }^{14}$ explica sobre o que o termo "verdade" pode designar nas obras de arte ou de ficção:

[...] qualquer coisa como a genuinidade, sinceridade ou autenticidade [...] ou a verossimilhança [...] não a adequação àquilo que aconteceu, mas àquilo que poderia ter acontecido; ou a coerência interna no que tange ao mundo imaginário dos personagens ou situações miméticas; ou mesmo a visão profunda [...] da realidade. [...] Graças ao vigor dos detalhes, à coerência interna, à lógica das motivações, à causalidade dos eventos etc., tende a constituir-se a verossimilhança do mundo imaginário.

Contudo, é fato que por volta de 1497, em razão de uma mudança nas leis ${ }^{15}$ na Península Ibérica, os bordéis foram obrigados a se afastarem do centro de Salamanca. Graças ao vigor dos detalhes e à coerência interna, quando Celestina vai à casa de Melibea, relembra à Lucrecia que não as visita desde que se mudou a outro bairro próximo ao rio: revela-se então a influência da prostituição na vida da Salamanca medieval aflorada por verossimilhança na obra.

${ }^{13}$ Aludimos às observações pedagógicas do professor Dr. Francisco Linares Alés de como apresentar aos alunos as obras literárias que constam no artigo eletrônico La Celestina: texto y cultura (Observaciones pedagógicas), consultado em dezembro de 2008 in http://bib.cervantesvirtual.com/bib_obra/celestina/enlaces.shtml.

${ }^{14}$ Rosenfeld (2004:29) ratifica que a "função narrativa no texto dramático se mantém [...] nas rubricas [...] extingue-se no palco, o qual, com os atores e cenários, intervém para assumi-la. Desaparece o sujeito fictício dos enunciados - pelo menos na aparência."

${ }^{15} \mathrm{O}$ estabelecimento de bordéis públicos nas cidades castelhanas nos anos de transição e ruptura das estruturas feudais para a Renascença forma parte de um conjunto de decisões políticas promovidas para acabar com a violência urbana e para fortalecer os mecanismos de controle do poder monárquico e municipal. Seguem as datas em que as diversas cidades peninsulares decidem relegar a prostitução às zonas claramente delimitadas, amuralhadas e afastadas do centro urbano: em 1444, Valencia; Segovia adota uma medida similar por Real Ordem em 1478; Málaga em 1489. A mesma política é adotada por Cuenca (1494), Córdoba (1498), Salamanca (1497) e Zaragoza (1472). Estas decisões obedecem a uma vontade de centralização da Monarquia aliada à autoridade municipal em preservar o principal fator de paz e ordem sociais nas urbes medievais: a integridade das alianças matrimoniais e a reputação das linhagens. 
Na Salamanca de 1498, um ano antes do qual teria sido publicada La Comedia de Calisto y Melibea, era o tempo em que as prostitutas, relegadas ao outro lado do rio, na periferia da cidade, partiam em barcas à Salud de Tejares para passar a quaresma, até a segunda-feira de Cuasimodo quando voltavam também em barcas. Os salmantinos reunidos à beira do rio e na ponte romana organizavam uma popular romaria na que não poderia faltar o famoso hornazo ${ }^{16}$, esperando a volta que não costumava ter hora marcada ${ }^{17}$. Outros documentos sobre essa tradição também foram encontrados nos escritos de alguns estudantes de Salamanca dos séculos XVI e XVII sobre a travessia de barco em busca de um dia no campo com as prostitutas que deveriam contribuir para a abstinência carnal dos católicos: era o chamado "Padre Putas" ou "Padre de Mancebía". Lembramos que, coincidentemente, Rojas diz no Prólogo que escreveu a obra nos quinze dias de férias da Semana Santa.

A segunda grande questão é um desdobramento natural da extratextualidade, a relação transtextual ${ }^{18}$ entre La Celestina e Cárcel de amor. Genette (1982) afirma que os textos não têm uma existência isolada e sim se parafraseiam uns aos outros, se citam, se explicam, interagem para dar lugar a novos textos. Demetrio Estebáñez Calderón, no seu artigo eletrônico $L a$ Celestina, texto clave en la crisis de los valores medievales y en la génesis del humanismo renacentista, chama de mutação, em especial a que culminou em $L a$ Celestina: mutação estética, ética-religiosa e moral. A mutação estética referida à La Celestina é a que afeta à mudança ocorrida no código literário vigente na poesia e na ficção sentimental do século XV, especialmente a estética do "amor cortês" presente na obra Cárcel de Amor, de Diego San Pedro.

A poética do "amor cortês" o fin'amors surgiu na literatura provençal no século XII e foi introduzida no transcurso dos séculos XIII e XIV na Península Ibérica através da Catalunha, da zona galego-portuguesa e de Castela onde atinge

${ }^{16} \mathrm{O}$ hornazo é uma iguaria salmantina como um empanado recheado de carne, presunto cozido, ovo etc.

${ }^{17}$ Atualmente, há uma festa tradicional conhecida por Lunes de Aguas (a segunda-feira seguinte ao da Páscoa) que se refere àqueles tempos em 1497 da proibição das prostitutas na região cêntrica das cidades como Salamanca.

${ }^{18}$ Segundo G. Genette (1982:35), é possível interpretar o Libro del Buen Amor como hipotexto e La Celestina como hipertexto por uma relação de transformação estrutural chamada de hipertextualidade. 
o maior desenvolvimento no século $\mathrm{XV}$, por dois subgêneros: a poesia amorosa cancioneira e a ficção sentimental, cuja principal representante é Cárcel de amor.

Podemos considerar como hipotexto Cárcel de amor, uma vez que La Celestina apresenta algumas semelhanças com essa obra encontrada na biblioteca de Fernando de Rojas, entre elas, a morte dos personagens como desfecho. Como Rojas, o autor de Cárcel de amor, Diego de San Pedro, apresenta ao leitor os "estragos" que o "louco amor" causa em suas vítimas, o amor como doença, o sentimento de tristeza como resultado da atitude de desdém da amada diante da insinuação amorosa, o paradoxo entre a paixão e a honra da dama, a rejeição ao casamento por parte dos amantes, o pranto final da mãe da protagonista.

$\mathrm{Na}$ ficção sentimental do amor cortês o amante vê a amada como a perfeição inatingível, visto que se concretizado esse amor, a tornaria igual às demais mulheres: imperfeita. Com a mutação em La Celestina, apesar de Calisto no primeiro ato descrever Melibea como símbolo da perfeição, anseia concretizar o seu amor. Aquela procura por um ideal inalcançável cria códigos que fazem com que o apaixonado seja um amante perfeito. $\mathrm{O}$ amor sem esperança o leva primeiro à frustração, depois ao desespero e, finalmente à tragédia que, em geral, o leva ao suicídio, segundo as observações de Wardropper ${ }^{19}$. O código estético do amor cortês surgiu do esquema de valores da sociedade feudal. O personagem apaixonado cultiva a vassalagem adiante da dama como um serviço de caráter obediente, submisso e secreto, portanto a discrição é fundamental para encobrir a identidade da dama e evitar a delação seguida da desonra.

$\mathrm{Na}$ ficção sentimental do fim do século XV os amantes, quando dominados por uma paixão frustrada, encontravam sua única saída na morte: esse era o fim natural do sacrifício consciente em virtude de uma nova fé, a do amor. Não foi este o motivo do destino de Calisto, cuja morte acidental, inútil, ridícula e cômica só contribui para desvelar a desonra de Melibea e, por outro lado, é o cumprimento de uma penitência trágica pelo descaso e egoísmo de somente se preocupar com a descoberta da sua própria desonra diante das mortes dos seus criados infiéis. Também não é o motivo do suicídio de Melibea que, desesperada

${ }^{19}$ WARDROPPER, Bruce W., El mundo sentimental de la Cárcel de amor. Madrid: Revista de Filología Española, XXXVII, 1953, pág. 174. 
pela morte do amante, não encontra nenhuma perspectiva de vida diante da paixão interrompida bruscamente.

Melibea teria de literalmente morrer de amor porque na ficção sentimental do fim daquela época essa era uma saída para a dor humana? Acreditamos que o evento da morte de Melibea é trágico e sobre essa natureza dramática do pranto de Melibea que precede o seu suicídio Severin (1977:697) afirma que:

\footnotetext{
Un ejemplo es el llanto de Melibea sobre la pérdida de la virginidad, también formado sobre un trozo del Corbacho, [...] Sus lamentaciones aun causan una reacción sarcástica en los criados de Calisto. Sosia, en un aparte, dice: "¡Ante quisiera yo oírte esos miraglos! Todas sabéis esa oración después que no puede dejar de ser hecho. ¡Y el bobo de Calisto, que se lo escucha!" (p. 192). Esto nos lleva a la pregunta, ¿qué tiene de gracioso la pérdida de virginidad, particularmente cuando el autor está preparando a Melibea para una muerte trágica?
}

A morte cômica de Calisto parodia a morte o suicídio de Leriano, o personagem heroico e apaixonado de Cárcel de amor que bebe a água na qual molhou as cartas apaixonadas que revelariam a identidade da sua amada para que, com esse nobre ato, a honra da amada permaneça limpa e a sua dor aplacada. Em contraponto, a morte tragicômica de Calisto mostra mais uma faceta grotesca do personagem tratado, de certa forma, de maneira esperpéntica. A morte de Calisto é o último ato paródico de este ser ficcional, ideia compartilhada por Severin (1977:697) quando afirma que "la muerte de Calisto, por otra parte, no es muy apropiada para un amante cortés recientemente rescatado de un papel puramente paródico". Levamos em consideração que a construção e a desconstrução dos modelos de heróis e anti-heróis do medievo contribuem para o desenvolvimento das formas paródicas dos personagens que os sucedem e compõem a base do romance. Temos no sentido paródico de La Celestina as características cômicas que se nutrem e se misturam às trágicas causando efeitos de sentidos verdade. Reconhecemos nessa obra as bases do teatro e do drama moderno exercendo fundamental papel de ponte para a construção de um modelo social, político e econômico que emerge, isto é, o surgimento da burguesia, coexistindo com o pensamento conservador da Inquisição.

Por essa razão, reconhecemos algumas coincidências entre La Celestina e Cárcel de Amor; entretanto, a mutação estética referida por Demetrio Estebáñez Calderón (1966:37) está em que o amor em La Celestina não se mantém unicamente no plano da sublimação do erotismo espiritual e do amor cortês, e sim 
se manifesta parodicamente no plano concreto: a relação carnal entre os amantes Calisto e Melibea promovida por Celestina e seus aliados.

O exemplo mais intrigante de hipertextualidade de La Celestina é o estabelecido pela transformação estrutural do personagem Trotaconventos do Libro del Buen Amor de Juan Ruiz, um hipotexto de 1330 que antecede a $L a$ Celestina em mais de século e meio. Um diálogo possível entre as duas obras é a menção ao personagem do hipotexto por Pármeno quando chama Celestina pela alcunha de trotaconventos no Ato II: "[...] y lo que más siento es que todo venga de manos de aquella trotaconventos". Cabe recordar que o termo "trotera" ou "trotadora de conventos" se referia às "cobigeras", que são as "dueñas" ou as monjas abadesas dos mosteiros que cuidavam das meninas internas.

Sobre o surgimento do tema da alcoviteirice Villanueva (1993: 15) já colocava a questão: “¿de dónde fundar uma obra como aquella sobre un tema como el de la alcahuetría? [...]¿Es tal vez casualidad que Juan Ruiz hubiera escrito ya otra obra maestra fundada sobre el mismo personaje base?". Podemos reconhecer entre as bases literárias de La Celestina o discurso e a linguagem da alcoviteira como um tipo social e sua relação com a sociedade urbana: "lo celestinesco está en ayudar por oficio y con espíritu demoníaco.” (Villanueva, 1993:16).

O Libro del Buen Amor - igualmente a La Celestina - é uma obra cujo tema principal é o amor, na qual Juan Ruiz, como Fernando de Rojas, também tem a intenção didata-moralizante de alertar o homem contra os perigos do "loco amor" que o afasta dos caminhos de Deus. No hipotexto vemos o "bom e o louco amor" e as diferentes situações para exemplificar todos os seus efeitos. O objetivo do amante, tanto de Arcipreste de Hita quanto de Calisto, é a satisfação sexual que, como nas duas obras, recorre a uma terceira pessoa para mediar a sedução. A Trotaconventos é um personagem análogo a Celestina em muitos aspectos como afirma Rubén Soto Rivera ${ }^{20}$ ao associar as palavras alcayata (tipo de prego com

${ }^{20}$ Rubén Soto Rivera no seu artigo Celestina, la de la cuchillada in

http://cuhwww.upr.clu.edu/exegesis/33/soto.html escreveu: "En el Libro del Buen Amor, o autor chama "a la alcahueta "maza", "almádana" (mazo de hierro para romper piedras), y "almohaza" (chapa de hierro que se usa para limpiar los caballos), "coraza", "aldaba", "garabato" (gancho de hierro para colgar cosas), "escofina" (lima), "aguzadera" (piedra de amolar), "campana", "alcayata" (clavo con gancho). Acerca de este último nombre, el manuscrito sustituye "alcayata" por "alcahueta"; pero ha sido enmendado por J. Corominas, porque cuadra mal con el 
gancho) e alcahueta ao ferro da espada: metaforicamente o poder da palavra persuasiva de ambos os personagens.

A Trotaconventos, assim como a Celestina, é uma mediadora que aconselha, insiste, mas, nesse caso contrariamente à segunda, o seu poder de persuasão fracassa, e, talvez por isso, diferentemente da Celestina, não é punida com a morte trágica.

A Trotaconventos aparece como mediadora pela primeira vez na quarta tentativa de um encontro amoroso do Arcipreste, depois de três anteriores frustradas. Diferentemente da Celestina que, além de ser anunciada desde o prólogo, é um personagem que aparece do primeiro ao décimo segundo ato. Mesmo depois da sua morte no décimo segundo ato, a sua presença continua repercutindo nas ações dos personagens que permanecem vivos.

No quarto episódio ${ }^{21}$ a Trotaconventos intercede perante a viúva sem que ninguém suspeitasse dela porque já estavam acostumados a vê-la de casa em casa vendendo joias. Fato que pode evidenciar que o personagem já tivesse livre acesso à casa dos nobres como mascate. Nesse sentido, a Trotaconventos atua como Celestina, que se apresentou à casa de Melibea sob o pretexto de vender um pouco de "hilado" - segundo José Bergamin (1952) um "hilado mágico"22 —, para ganhar dinheiro para o seu sustento e o das suas "mochachas" também. Esse foi o primeiro fracasso da Trotaconventos apesar da sua insistência para que se confirmasse o relacionamento entre eles. Celestina também fracassou nas três primeiras tentativas para convencer Pármeno a ser seu aliado.

Diante do fracasso amoroso anterior, no episódio seguinte o Arcipreste se interessa por outra mulher, por isso envia a Trotaconventos para intermediar e convencê-la a recebê-lo. Essa vai a sua casa para convencê-la de que é "melhor ter um amante vivo que um marido morto". Ser amantes também é o que os personagens procuram em La Celestina, não se menciona casamento como meio

juego de metáforas, presente en los nombres de la alcahueta; mas desde nuestro punto de vista el binomio alcayata-alcahueta es sintomático.”. (Artigo eletrônico consultado em março de 2009)

${ }^{21}$ Trata-se de um episódio com a rica viúva e vizinha Doña Endrina e Don Melón de la Huerta substitui o "eu" narrador.

22 José Bergamín (1952:61): “en el hilado mágico de Celestina va preso el espíritu, un espíritu... (un "espíritu de amor”, dirá Dante) que entra por los ojos o por los oídos o por la boca, que entra por los sentidos todos, para prendernos en la sangre su invisible llama, llama viva de amor, llama inextinguible, perdurable, eterna, más acá y más allá de la muerte.” 
para concretizar o amor. Nesse episódio se evidencia outro fracasso persuasivo da Trotaconventos como mediadora - diferentemente da mediadora Celestina quando essa mulher que rezava prefere se casar com um cavaleiro.

No sexto episódio a Trotaconventos aconselha o Arcipreste a se casar com uma freira encontrada em um convento. Encontra doña Garoza que não aceita nenhuma sugestão da alcoviteira. Celestina também aconselha a Areúsa a receber Pármeno como amante para conquistá-lo como aliado e, diferentemente da Trotaconventos, obteve sucesso na empreitada.

Pela hipertextualidade é possível traçar algumas reflexões sobre as duas alcoviteiras medievais, a Trotaconventos e Celestina:

1. através da alcoviteirice ambos os personagens exercem a sua principal característica: a arte da persuasão. A diferença é que Celestina alcança o seu objetivo, o de receber dinheiro e joia, porque consegue, seja pela sua arte em persuadir, seja pelo seu pacto com Plutão, seja porque Melibea já estaria ocultando sua paixão por Calisto desde o encontro na horta ou por todos esses motivos, juntar os amantes. A consequência dos atos da Celestina - a avareza, a cobiça, a luxuria, o egoísmo - , a levam à morte trágica. A Trotaconventos falha em todas as tentativas de fazer do Arcipreste um amante da suas pretendentes, entretanto não tem o mesmo "castigo" que a sua sucessora, a morte trágica;

2. as mediadoras amorosas encontram o lugar propício para exercer a sua arte de persuasão nas cortes e no seio de uma nobreza aristocrata e na alta burguesia de Castela, ávidas em ver celebradas as suas façanhas e de ver engrandecida a sua fama em contradição às velhas leis cortesãs, incapazes de aceitar o mundo pré-buguês que vem adquirindo espaço na transição para as novas relações sociais da Idade Moderna. Celestina e a Trotaconventos tentam ou unem os amantes da nobreza por causa do pagamento que recebem por esse trabalho;

3. a necessidade moral em rejeitar a paixão visa conservar a honra e a virtude das donzelas. Em consequência, o final trágico serve como exemplo moral para os jovens apaixonados. A paixão amorosa para a Igreja da época é um pecado inclusive entre o casal. O casamento, como instituição social, é incompatível com o amor desenfreado dos apaixonados. Os apaixonados encontram na alcoviteira o personagem facilitador para transgredir as regras sociais impostas pela Igreja e pela sociedade em crise dos valores medievais; 
4. a mediação, veículo para concretizar os encontros amorosos entre os nobres e através da figura de uma mulher da classe baixa com fluxo entre a nobreza, se faz necessária como tentativa para seduzir a dama, infringir os costumes, romper as barreiras e expressar a inconformidade social da época; e

5. finalmente, a conjunção dos aspectos da história social da época reflete as relações entre texto e cultura: a Igreja inquisitorial, os casamentos entre os nobres arranjados por dote, o amor e as facilitadoras amorosas culminam em personagens da literatura.

Hoje, à luz da literariedade, podemos estabelecer um diálogo entre $L a$ Celestina e algumas das características da picaresca e do esperpento de forma precursora, pois todas carregam o traço da deformação grotesca da realidade a serviço de uma implícita intenção crítica da sociedade.

Quanto ao primeiro, o diálogo com a picaresca se dá especificamente no que tange ao conceito social, religioso e moral proveniente do contraste cotidiano entre dois estratos sociais, o dos nobres e o dos criados. A crítica dos valores dominantes da honra e da hipocrisia dá vazão à falácia, à mentira, à infidelidade, à vingança e ao rancor como meio de sobrevivência.

A paródia ao romance sentimental e ao amor cortês aparece no tema celestinesco protagonizada pela antiheroína, a antidama e o anticavalheiro. Enquanto, na picaresca, o personagem pícaro anseia a ascensão social - como podemos verificar em La Celestina o mesmo desejo em Sempronio -, a ressalva é que Celestina não aspira melhorar sua condição social - não pretende mudar seus ofícios, pelos quais não os esconde além de sentir orgulho deles —, aspira sim ter dinheiro para manter seu prazer à mesa e sobreviver à velhice, para sustentar seu caráter hedonista. A importância que adquire o dinheiro e a riqueza na vida do personagem tem o mesmo destaque que o prazer sexual na obra. $\mathrm{O}$ destaque que tem o dinheiro na trajetória de Celestina a conduz à cobiça e à avareza, colocando em crise os ideais heroicos e religiosos em oposição à ascensão dos valores burgueses.

A ideologia burguesa, o tema moralizante e o pessimismo tanto do romance picaresco como do tema celestinesco dialogam desde uma perspectiva final de desengano: um grande exemplo de conduta aberrante que, sistematicamente, resulta castigada. Tanto a picaresca quanto os temas do amor e da fortuna na obra estão muito influenciados pela retórica sacra da época, baseada 
em muitos casos, na predicação de exemplos, nos que se narra a conduta desviada de um indivíduo que, finalmente, é castigado ou se arrepende. Ramón del Valle Inclán (1866-1936) já reconhecia em La Celestina afinidades com o romance picaresco:

Acaso la gran novela española, empieza en la Celestina. [...] Apenas establecemos juicio novelesco a partir de la Celestina que marca el camino de la novela picaresca. (Valle Inclán, en entrevista a Eduardo M. Montes. El Castellano. Burgos, 23 de octubre de 1925, apud VALLE-INCLÁN, 1995, p. 285).

A respeito do diálogo com o esperpento, criado pelo autor supracitado, Valle Inclán afirmava que "o sentido trágico da vida espanhola só pode se oferecer com uma estética sistematicamente deformada" —, podemos inferir que a afinidade com La Celestina não está tão somente pela deformação grotesca da realidade, mas também por estar a serviço de uma implícita crítica da sociedade desigual mostrada como imagem fiel e realista. Acrescentamos ao caráter esperpêntico em La Celestina o desmascaramento da imagem aparente que se tem dos personagens para revelar o lado da degradação moral de cada um, a deteriorização dos valores morais e éticos quando tomam consciência dos problemas sociais ocultados pelo convencionalismo e pelo conservadorismo.

O personagem Celestina é o retrato da degradação moral da sociedade que busca a fortuna e a riqueza como valor principal e, por isso, ao ser levado à morte por trair os sócios - é a punição pela cobiça ao dinheiro e avareza em detrimento da amizade nas relações humanas —, responde à visão grotesca e realista da sociedade espanhola. Antes de morrer, porém, a velha corrompe os criados contra o seu amo, leva a dama a romper com as convenções sociais de castidade, engana os homens ao tornar virgens suas amantes, dá guarida às relações amorosas dos membros da Igreja, fabrica ilusões com a arte de cosméticos e perfumaria. As relações humanas na obra são coisificadas e acontecem em ambientes como ruas, prostíbulos e bordéis, por isso todos os relacionamentos de amor, de servidão e de amizade entre os personagens - tanto entre os nobres como entre os criados e as prostitutas — são volúveis.

Além do grotesco temos o burlesco na linguagem mista de Celestina, que "literaturaliza" o coloquial de maneira verossímil. O personagem investe nas citações a Aristóteles, Petrarca, Sêneca como argumento de autoridade, alude a passagens bíblicas para apelar à religiosidade, abusa dos contrastes para criar mais 
persuasão ao seu discurso, com a mistura do real e do seu desejo em causa própria, distorce os fatos ao seu favor de forma burlesca. Contudo, a principal característica presente na obra e no esperpento é o significado profundo e carregado de crítica e intenção satírica constituindo a autêntica lição de moral pretendida por Rojas, anunciada no Incipit, punida com a morte, como no esperpento.

Antes que se conhecessem os preceitos do teatro moderno, Rojas criou o espaço da cidade como o grande cenário de La Celestina, cujos espectadores e atores são os próprios personagens que se deslocam entre as casas de Calisto, Celestina e Melibea. Os apartes e monólogos, presentes no teatro, revelam os sentimentos dos personagens sem que fosse imprescindível um narrador que os revelasse aos leitores; os diálogos apresentam apenas o que os personagens querem que os demais saibam. Personagens com características pícaras como Sempronio e Pármeno também estão presentes na obra. No precedente cenográfico proposto pelo esperpento como modalidade teatral vemos as contínuas mudanças de palco bem como a profusão de histórias durante o desenvolvimento da obra, que finalmente acabam por se cruzar. Tanto no incipiente Renascimento de Rojas de cultura humanista quanto no esperpento os clássicos são retomados, o sentido trágico da vida espanhola é deformado e exagerado para espelhar a sociedade que está no limiar da grandeza e do grotesco.

Em síntese, a deformação da realidade que ocorre tanto no esperpento quanto em La Celestina deixa transparecer a condição humana, o antropocentrismo e o debate intelectual. Ambas as obras deformam em caricatura grotesca a condição humana diante das circunstâncias históricas da Espanha, cada uma no seu momento. A cena da morte do personagem Celestina alude não só à mediocridade social, como também a alguns seres ficcionais grotescos que geralmente padecem de algum tipo de alienação provocada pela ignorância ou pelo egoísmo reinantes, por isso não se preocupam em discernir o justo do injusto, o correto do incorreto, pautando-se sempre pelos seus interesses pessoais. No ambiente esperpêntico a crítica ao sistema sócio-político espanhol é realizada com elementos paródicos e satíricos.

Contudo, apesar das raizes esperpênticas, não consideramos que a obra de Rojas seja tão somente e essencialmente um esperpento, pois não reconhecemos em La Celestina uma estética tão desfigurada a ponto de transformar por completo 
a imagem aparente da realidade para ser mostrada como ela realmente é, ou seja, absurda e grotesca como Valle-Inclán criara quatro século depois. Ao tomar como referência o teatro esperpêntico deste autor do século $\mathrm{XX}$ - em que nada escapa ao processo de deformação - verificamos que, em contrapartida, nem tudo é deformado em La Celestina. Rojas contrapõe as figuras gananciosas chefiadas por Celestina e seus antagonistas Pármeno e Sempronio às figuras alienadas pela paixão como Calisto e Melibea. Pármeno, por exemplo, pode ser visto como a representação da Espanha devastada, e sua imagem quase chega à idealização.

Os elementos dramáticos e teatrais da ficção no esperpento interagem conflitivamente com a realidade social parodiando a condição humana diante da sua da existência. Cenários, personagens, apartes, diálogos e gestos estão ao serviço da tragédia e da farsa concomitantemente. Neste ponto, La Celestina e o esperpento dialogam harmonicamente, apesar dos cinco séculos que as separam.

\section{Celestina: voz e corporalidade}

Os aspectos psicológicos do caráter de Celestina como enunciadora ligamse ao éthos discursivo do personagem principalmente através das escolhas linguísticas feitas por ele. São essas escolhas que revelam as marcas sobre a imagem do próprio orador, continuamente construída no âmbito discursivo. Maingueneau (2006) afirma que este se liga diretamente ao tom que engendra o discurso. Esse tom, por sua vez, estaria ligado a uma corporalidade e ao caráter do enunciador. Segundo o mesmo autor (1997:46), “a Retórica antiga organizava-se em torno da palavra viva e integrava, consequentemente, à sua reflexão, o aspecto físico do orador, seus gestos, bem como sua entonação”. Nos textos escritos não há a representação direta dos aspectos físicos do orador - ainda que Celestina seja descrita física e psicológica pelos demais personagens-, mas há marcas que indicam e levam o coenunciador a atribuir uma corporalidade e um caráter ao enunciador - ingredientes das zonas indeterminadas suscitadas pelo texto nos destinatários - , categorias essas que interagem no campo discursivo. Para o referido autor, o caráter seria “o conjunto de traços psicológicos que o leitorouvinte atribui espontaneamente à figura do enunciador, em função de seu modo de dizer" (MAINGUENEAU, 1997, p. 47), enquanto a corporalidade remeteria a uma representação do corpo do enunciador, construído no processo discursivo. 
Podemos afirmar que o éthos de Celestina se relaciona com a construção de uma corporalidade enquanto enunciadora por intermédio de um tom lançado por ela no âmbito discursivo. O tom nos permitirá construir, no texto escrito, uma representação subjetiva do corpo da enunciadora, corpo este manifestado não fisicamente, mas construído no âmbito da representação subjetiva. A imagem corporal de Celestina enquanto enunciadora faz emergir a figura do fiador, entendida aqui como aquela que deriva da representação do corpo do enunciador efetivo, construindo-se no âmbito do discurso. O fiador é aquele que se revela no discurso e não corresponde necessariamente ao enunciador efetivo.

No âmbito discursivo, podemos criar a imagem de uma fiadora experiente e sábia, mesmo que Celestina não tenha essas características, mas as escolhas lexicais feitas por ela vão conferir ao enunciado um tom de experiência e sabedoria. Delas emerge a imagem de uma fiadora experiente e sábia. Para Maingueneau (2005), o fiador é uma imagem construída pelo destinatário com base em indícios textuais de diversas ordens.

Uma das marcas na história da literatura do personagem Celestina é o poder de verossimilhança física e psicológica com uma pessoa com qualidades e vícios realmente humanos. Sua existência como ser ficcional na obra se justifica porque a sociedade da época não só requisitava os seus serviços e necessitava dos seus ofícios, como também exigia que ela ocupasse seu espaço reconhecido por todos os personagens na vida social urbana. Celestina reflete um tipo social que, por causa do crescimento do seu protagonismo - que atende à demanda dos seus leitores os quais se veem refletidos na trama - faz com que a obra mude de Tragicomedia de Calisto e Melibea, título que realça as ações e os sentimentos dos ricos, a La Celestina, que reflete melhor o sucesso das artimanhas do personagem. Gilman (1978:31) também confirma a ascensão do papel da velha senhora nos meios editoriais: "sólo la voz autónoma y consecuente de Celestina se enseñora de la obra, imponiendo una unidad que va a reflejarse en el título".

Intencionalmente, Rojas concede a Celestina o papel de eixo da união amorosa entre os demais personagens. Com a função de unir os casais, o personagem alcança subverter o prazer sexual ao explorar sagazmente os contrastes entre os pares: os jovens e idealistas Pármeno e Areúsa, os mais experientes e cínicos Sempronio e Elicia, os ricos e ingênuos Calisto e Melibea. Como eixo das relações amorosas, todos os personagens se entrelaçam através da 
sua arte da persuasão e giram todas as ações dos pares. Na relação de causa e efeito, a consequência das ações de Celestina leva estes casais às drásticas mudanças na trajetória de vida ocorridas em curtíssimo tempo, dois ou três dias talvez, até o momento fatal em que a cobiça a impede de ver o que aquela cicatriz do rosto já assinalara: a sua própria morte se daria de maneira retoricamente trágica ao ser traída pelas vítimas da sua língua afiada.

Através da descrição que Pármeno faz de Celestina a Calisto podemos acrescentar que o traço logocêntrico da cicatriz é mais um recurso retórico do autor para aludir a um sinal que o demônio deixava no rostro de seus adeptos como prova irrefutável para condenar bruxas e feiticeiras e também uma marca infamante das prostitutas: “[...] un poquito de bálsamo tenía ella en una redomilla que guardava para aquel rascuño que tiene por las narices".(Ato I, Cena 7, p. 154)

Portanto, corroboramos com Gilman quando coloca que Fernando de Rojas alcançou a "alta perfección", através de vozes que parecem autônomas: “[...] los interlocutores y particularmente esa gran maestra del lenguaje hablado, Celestina, se apoderan de La Celestina, pareciendo - en una especie de apoteosis pirandeliana - como si fueran sus autores". (1978:33)

Com expectativas realistas, Celestina é o personagem que, apesar de ser a que mais tem confiança e consciência de si própria ${ }^{23}$, está "encerrada en si misma" (Malkiel, 1962:506). Como não pertence nem ao grupo dos amos, nem ao dos criados, é o personagem mais independente e, em todos os sentidos, também a figura mais livre de toda a obra, pois tem igual acesso a todas as castas sociais. Essa libertade também é notada na sua linguagem, mais coloquial e popular quando interage com os criados e mais erudita quando Melibea e Calisto são seus destinatários.

Celestina é consciente do seu afã de ganhar dinheiro, mas não de todas as consequências que isso possa causar e, quando descobre os reais resultados da subversão moral que gerou, já é muito tarde para evitar a reação violenta dos seus interlocutores. A morte é uma das suas constantes preocupações, ainda que como um acontecimento natural da vida, embora exalte o carpe diem insistentemente e alegue que por ser velha é mais experiente que os demais personagens.

${ }^{23}$ Berndt, Erna Ruth. Amor, muerte y fortuna em “La Celestina”. (1963:173), escreve: “ Celestina es el personaje que más fe tiene en sí mismo" 
Antes de o personagem morrer em função da falta de adaptação do seu discurso às novas circunstâncias, o leitor o reconhece por seu comportamento hedonista, sempre buscando o prazer como motivação fundamental: o prazer da mesa, pelo vinho. Já na velhice e outrora como prostituta, para garantir esse prazer, a velha precisa ganhar dinheiro: assim, ela usa o poder da palavra como arma para fazer negócio através da mediação amorosa. A liberdade em poder escolher o seu destino e a preocupação com o seu bem-estar faz dela um personagem avarento: o dinheiro é a única garantia para o seu futuro. Francisco L. Alés $^{24}$ afirma que:

La Celestina expresa el conflicto con el que arranca la história moderna, y que todavía sigue sin resolver: la duda sobre si el placer y el dinero justifican todo comportamiento o, por el contrario, acarrean resultados catastróficos para la persona y la sociedad.

Por não ter compromissos sociais e encontrar-se à margem da sociedade, entre outros aspectos, alguns críticos como J. G. Maestro ${ }^{25}$, a consideram niilista:

\begin{abstract}
Nihilista es aquel personaje que por su condición, es decir, por su conocimiento del mundo y por sus necesidades vitales, no puede ser ni sincero ni inocente. Su conocimiento (saber) de la realidad, su voluntad (querer) de acción, y sus posibilidades (poder) para llevar a cabo sus propósitos, le inducen a negar la validez del orden moral trascendente, con el fin de justificar por sí mismas sus propias formas de conducta, es decir, con el fin de legitimarlas por referencia a un código de valores absolutamente personal. (2001:27)
\end{abstract}

O modo de vida de Celestina nos é apresentado pelos demais personagens, aliás, é o único personagem de passado conhecido pelo leitor. De acordo com Miguel Rodríguez Mondoñedo no seu artigo intitulado "Notas sobre os ofícios de

${ }^{24}$ Conceito extraído do artigo La Celestina: texto y cultura (Observaciones pedagógicas). Centro de Lenguas Modernas de la Universidad de Granada in http://oldwww.upol.cz/res/ssup/hispanismo1/linares.htm (consultado em janeiro de 2009).

${ }^{25}$ J. G. Maestro in Tragedia, comedia y canon desde la teoría literaria moderna. El personaje nihilista de La Celestina. Universidad de Vigo (artigo eletrônico consultado em março de 2009), afirma que "la esencia de la experiencia trágica emana de la existencia de un conflicto real entre la libertad de la voluntad del sujeto y la causalidad objetiva e inmutable de un orden moral trascendente, que impone al ser humano el inevitable desenlace de una serie de hechos previamente determinados." in www.cervantesvirtual.com/servlet/SirveObras/01482307989032788550035/index.htm (artigo eletrônico consultado em janeiro de 2009). 
la Celestina", o personagem tem vários ofícios não só como recurso estilístico para atribuí-los ao seu caráter e demonstrar assim as suas habilidades e defeitos, mas como pano de fundo para transparecer a crise do ideal de unidade medieval.

Os vários ofícios de Celestina são comprovadamente reconhecidos quando, na casa de Pleberio para falar com Melibea, Alisa interrompe a conversa entre Celestina e Lucrecia para perguntar à criada com quem estava falando, ao que Lucrecia responde: "con aquella vieja de la cuchillada que solía vivir en las tenerías a la cuesta del río". Essa informação é insuficiente para que Alisa se lembre de Celestina, por isso volta a questionar Lucrecia: “¿Qué oficio tiene? Quizá por ahí la conoceré mejor". Os ofícios de Celestina lhe servem de cartão de apresentação para entrar na casa dos nobres, ao que Lucrecia completa: “[...] perfuma tocas, hace solimán y otros treinta oficios. Conoce mucho en hierbas, cura niños y aun algunos la llaman la vieja lapidaria".

Pármeno também conhecia Celestina desde pequeno quando sua mãe, uma prostituta que o deixou aos seus cuidados, comenta com Calisto sobre seis ofícios dela: lavadeira, perfumista, mestra em preparar cosméticos e compor virgens, alcoviteira e feiticeira.

[...] Ella tenía seys oficios, conviene saber: labrandera, perfumera, maestra de fazer afeytes y de fazer virgos, alcahueta y un poquito hechizera. Era el primero oficio, cobertura de los otros, so color del qual muchas mozas, destas sirvientes, entravan en su casa a labrarse y a labrar camisas y gorgueras y otras muchas cosas. (I, Cena 7, p. 150)

Villanueva (1993:28) descreve como a alcoviteirice era encoberta por tantos outros ofícios como o de vendedora ambulante, curandeirismo, quiromancia, tecedora etc. para que o personagem, presente em tantos livros de amor orientais, pudesse ter livre trânsito entre as casas das mulheres honestas e seus amantes.

Asaz era amiga de estudiantes y despenseros y moços de abades y a éstos vendía ella aquella sangre inocente de las cuytadillas, la qual ligeramente aventuravan en esfuerço de la restitución que ella les prometía. (Ato I, Cena 7, p. 151)

Ao ser perguntado por Calisto Pármeno descreve com detalhes o que Celestina fazia: 
[...] fazíase física de niños, tomava estambre de unas casas, dávalo a filar en otras por achaque de entrar en todas [...] fazía ella sus aleluyas y conciertos [...] fazía perfumes; falsava estoraques, menjuý, animes, ámbar, algalia, polvillos, almizcles, mosquetes [...] hazía solimán, afeyte cozido [...] adelgazava los cueros con çumos de limones [...] sacava aguas para oler [...] hazía lexías para enrubiar [...] estos de los virgos, unos hacía de bexiga y otros curava de punto [...] quando vino por aquí el embajador francés, tres vezes vendió por virgen una criada que tenía. (Ato I, Cena 7, p. 152-4)

Para justificar a necessidade do seu tipo social, Celestina coloca que ninguém lhe impôs os múltiplos ofícios que exerce; ela os escolheu por necessidade de garantir sua sobrevivência e o seu prazer à mesa, o que nos é sugerido pelas suas próprias palavras:

Pocas vírgines, a Dios gracias, has tú visto en esta ciudad, que hayan abierto a vender, de quien yo no aya sido corredora de su primer hilado... ¿Auíame de mantener del viento? ¿Heredé otra herencia? ¿Tengo outra casa ó viña? ¿Conócesme outra hacienda, más deste oficio? ¿De qué como é beuo? ¿De qué visto é calço? Em esta cibdad nascida, em ella criada, manteniendo honrra, como todo el mundo sabe ¿conoscida pues, no soy? Quien no supiere mi nombre é mi casa tenle por estranjero. (Ato I, p.133)

Villanueva (1993:112) confirma que a arte da alcoviteira sob o disfarce de atividades inocentes continua sendo nelas uma presença facilmente documentável, desde a literatura arábica do século IX, passando ainda pelo século XIV, cujas artimanhas diabólicas contra a castidade feminina se manifestam através de um "personaje de cuya boca salen toda suerte de engaños e incitaciones pecaminosas".

Celestina foi companheira de Claudina, mãe de Pármeno, prostituta que morava em uma casa ainda no centro da cidade. Sobre a localização da casa da alcoviteira, Pármeno relata a Calisto:

Pero en aquel poco tempo que la serví, recogía la nueva memoria lo que la vejez no ha podido quitar. Tiene esta buena dueña al cabo de la cibdad, allá cerca de las tenería, en la cuesta del río, uma casa apartada, médio caýda, poco compuesta y menos abastada. (Ato I, Cena 7, p. 149)

Foi vizinha da casa de Pleberio quando intermediava encontros entre religiosos e prostitutas, época em que a prostituição não havia sido proibida por lei nos centros das urbes, e depois se mudou para um casebre próximo ao rio, já fora do perímetro da cidade. 
A madre, como é chamada Celestina pelos demais personagens, já está velha para ganhar dinheiro como prostituta. E, se por um lado a sua velhice é associada à maldade, ao vício, à morte e a estar à margem da sociedade, porque já não pode cumprir o principal papel da mulher no meio social, que é a maternidade, por outro, lhe concede a sabedoria pela experiência vivida e a certeza de procurar recursos para garantir a sua sobrevivência e os prazeres à mesa.

Essa necessidade de garantir seu sustento faz com que Celestina se destaque pela avareza e pelo desmedido afã de lucro. No primeiro ato, quando Sempronio the procura para propor o negócio com Calisto, a velha já denuncia os seus sentimentos: "Dile que cierre la boca y comience abrir la bolsa; que de las obras dudo, quanto más de las palabras." (Ato I).

Juntamente com a astúcia, a luxúria e a cobiça, a avareza corruptora está enraizada na consciência popular da época, segundo Maravall (1986:15): "El dinero, según la estimación de la época, está en el origen de la agudización del mal de la codicia que se sufre".

Rojas parece não só ter aplicado todos os vícios humanos merecedores de condenação, todos os pecados capitais em Celestina, mas também sentimentos de angústia, medo, aflição e incerteza, uma constante nos seus monólogos dialogados e microdiálogos. Ao deliberadamente transgridir as leis religiosas para alcançar as paixões humanas, a velha procura completar-se em si mesma e, ao fazer essa reflexão, dialoga com o discurso de outrem, fundamentada na ideia de que "a tarefa polifônica é incompatível com uma só ideia " (Bakhtin, 1981:65). Assim, corroboramos com a definição de Bakhtin de monólogo dialogado, ou microdiálogo - momentos em que o personagem revela o éthos efetivo, exteriorizando sua intimidade através da sua consciência desintegrada. Esses sentimentos são evidentes quando vai à casa de Melibea para cumprir mais uma missão argumentativa, ou no seu monólogo nocturno quando, temendo um possível tombo por causa dos buracos na estrada, volta sozinha para casa à noite. Naquele monólogo, o personagem expressa a necessidade de outra consciência, um outro discurso, que ecoe as múltiplas vozes e ideias de outros campos de visão e concepção de mundo. É o momento em que ela tem maior consciência de si ao expressar-se em primeira pessoa — “[...] si no voy [...] — sobre o que pensam os demais personagens sobre ela: “[...] ¿qué dirá Sempronio? [...] y su amo Calisto?” 
Si no voy, ¿qué dirá Sempronio? ¿Qué todas éstas eran mis fuerças, saber y esfuerço, ardid y ofrecimiento, astucia y solicitud? Y su amo Calisto, ¿Qué dirá, qué hará, qué pensará sino que ay nuevo engaño en mis pisadas y que yo he descubierto la celada por haver más provecho desta otra parte, como sofistica prevaricadora? $\mathrm{O}$, si no se le ofrece pensamiento tan odioso, dará bozes como loco. Diráme en mi cara denuestos rabioso; proporná mil inconvenientes que mi deliberación prestale puso, diciendo: “tú, puta vieja, ¿por qué acrescentaste mis pasiones con tus promessas? ¡Alcahueta falsa, para todo el mundo tienes pies, para mí lengua; para todos obra, para mí, palabras; para todos remedio, para mí, pena; para todos esfuerço, para mí, falta; para todos luz, para mí, tiniebla! Pues, vieja traydora, ¿por qué te me ofreciste? Que tu ofrecimiento me puso esperança, la esperança dilató mi muerte, sostuvo mi vivir, púsome título de hombre alegre. Pero no haviendo efeto, ni tú carecerás de pena ni yo de triste desesperación.” Pues, ¡triste yo! Mal acá, mal acullá, pena en ambas partes! Quando a los estremos falta el medio, arrimarse el hombre al más sano es discreción. (Ato IV, Cena 1, pp.208-209)

O microdiálogo de Celestina vai frontalmente contra a base filosófica do texto monológico - aquele que vem do princípio monístico da unidade do ser porque ela necessita da existência do outro para seu crescimento como ser humano - "diráme en mi cara denuestos rabioso" - e para tornar sua visão de mundo mais complexa e mais rica. Ao se tornar mais profunda - "quando a los estremos falta el medio, arrimarse el hombre al más sano es discreción”-, terá mais possibilidades de interação com os seus destinatários porque leva em conta a necessidade da outra voz. Celestina não coincide consigo mesma e reflete isso dentro do seu discurso porque já contém o outro dentro de si. Ela mesma e a sua autoconsciência vivem da sua característica de ser inacabado, em eterna formação. Ela se constrói, destrói e reconstrói até atingir, por um processo dialógico e dialético, a maturidade de refletir sobre si e seu mundo, sem respostas prontas ou fechadas. Celestina reflexiona sobre o que Calisto pensará dela se não for à casa de Melibea: “proporná mill inconvenientes que mi deliberación prestale puso, diciendo: "tú, puta vieja, ¿por qué acrescentaste mis pasiones con tus promessas?". É o ser ficcional no seu limite como ser racional. A inconclusibilidade é uma contradição inerente a todo ser humano, que, segundo Bakhtin, dão verossimilhança aos personagens.

De acordo com Bakhtin (1981:73)

[...] é somente quando contrai relações dialógicas essenciais com as ideias dos outros é que a ideia começa a ter vida, isto é, a tornar-se, desenvolver-se, a encontrar e renovar sua expressão verbal e gerar novas ideias. 
Portanto, a troca ideológica gera a autenticidade do discurso. São muitos os elementos que contribuem para a construção do "intercambio discursivo", da "textura polifônica" na qual confluem, se entrecruzam, se metamorfoseiam, se corroboram ou se contestam outros textos, outras vozes e outras consciências" (op. cit. 93).

Rojas alcança o conceito de polifonia ao tratar os personagens com uma relativa liberdade e independência, criando espaços para que os questinamentos de Celestina gerem mudanças nos seus traços sociais individuais. Bakhtin (1981:39) enfatiza que "esses personagens em constante mudança em função do outro são mais interessantes" diante do mundo e sobre si mesmos a partir da relação do indivíduo com sua autoconsciência: "para todo el mundo tienes pies, para mí lengua; para todos obra, para mí, palabras; para todos remedio, para mí, pena; para todos esfuerço, para mí, falta; para todos luz, para mí, tiniebla”. O personagem define o que caracteriza a sua imagem diante do outro ao se tornar dono do seu discurso, liberando a voz monológica do autor: “pues, ¡triste yo! Mal acá, mal acullá, pena en ambas partes!". O mundo e a sociedade interferem na formação da autoconsciência de Celestina que escolhe os traços da realidade para o seu discurso: “¡alcahueta falsa, para todo el mundo tienes pies, para mí lengua $[\ldots] "$.

Externamente, a verossimilhança física se dá quando é conhecida por ser "a velha da cicatriz" ${ }^{\prime 26}$, feia, bêbada e barbuda. A barba é essencialmente um símbolo masculino, de honra e poder. Lillian Von der Walde Moheno ${ }^{27}$ afirma que:

Ser "barbuda" es característica que, como se observa, se halla asociada a otras, entre las que destacan: sagacidad, desverguenza, lujuria, maldad demoníaca. Se trata de una suerte de amplificatio pues, de hecho, tal solo elemento fisonómico implica todo lo demás. Las barbas en la mujer se producen en virtud de la retención menstrual, y la menstruación es venenosísima (Canet); también, la retención conduce al aumento del calor corporal, con lo que se eleva el deseo concupiscente [...] (2007:132)

${ }^{26}$ Pármeno conta a Calisto que la puta velha tinha "un poquito de bálsamo en una redomilla que guardaba para aquel rascuño que tiene por las narices" (I.7.244). Melibea também a reconhece pela cicatriz: "Así goce de mí, no te conociera, sino por esa señaleja de la cara" (309). Sua criada Lucrecia sabe quem é Celestina: aquella «vieja de la cuchillada [...] que vendía las moças a los abades».

${ }^{27}$ MOHENO, Lillian von der Walde. El cuerpo de Celestina: un estudio sobre fisonomía y personalidad in Revista eHumanista: Volume 9, 2007 
A cicatriz pode ter sido causada por uma facada. Lillian Von der Walde Moheno (2007) afirma que tanto a barba quanto a cicatriz são características fisionômicas que remetem à corrupção fruto da doença da alma, que "de no curarse merece la muerte":

\begin{abstract}
En realidad, la seña en la nariz es un signo polivalente de carácter negativo. En primera instancia refiere a una mujer marcada, lo que se extiende semánticamente a asuntos de conducta; existía, por ejemplo, la amenaza "cruzar la cara," que en una de sus acepciones significaba herir el rostro con navaja o cuchillo. La seña, por tanto, indica un pasado violento. Ahora bien, la criada Lucrecia refiere la cicatriz como "dios os salve" (fol. 20r), que si bien en el español antiguo significaba cuchillada en la cara (Russell 110, n. 60) y parece contener un buen deseo para alguien que anda en pendencias, puede aducirse otro sostén fisonómico al porqué del llamado a la divinidad. (2007:136)
\end{abstract}

A cicatriz do rosto de Celestina denota o que ela tem de mais afiada, a língua, comprovadamente usada para persuadir os personagens em benefício próprio. Se, por um lado, o retrato desenhado pelo que os personagens contam dela reúne elementos tópicos de índole negativa, associados à maldade e a uma série de preconceitos contra a magia, a prostituição, a velhice, a pobreza e a feiúra, por outro, são deixados de lado quando a sociedade necessita dos seus préstimos para concretizar seus desejos.

\title{
Conclusão
}

O personagem Celestina é fruto do enfrentamento do indivíduo com o seu meio social, consciente do seu valor como indivíduo e da sua dimensão pessoal, embora ambicione riqueza para ter uma velhice abonada através de mediação amorosa, feitiçaria, curandeirismo, etc. Graças ao choque entre querer ser uma coisa e ter de ser outra, o personagem está em conflito, seus sentimentos são contraditórios: as relações humanas são pervertidas e o amor, coisificado.

Como eixo das ações dos personagens por isso é imprescindível à trama, Celestina os entrelaça pela interrelação entre os que servem e os que são servidos: Calisto depende dos seus criados e dela; ela não pode atuar livremente sem a cumplicidade de Sempronio e Pármeno; as prostitutas Areúsa e Elicia são necessárias para sustentar o apoio dos criados; Lucrecia facilita seu acesso a Melibea e os encontros desta com Calisto. Melibea precisa de Celestina para realizar seu desejo por Calisto. As prostitutas, discípulas de Celestina, se servirão 
de Sosia e Centurio para levar a cabo seu plano de vingança e, por sua vez, Centurio se apoiará em Trasso para agradar a Areúsa.

Como Celestina promove a interrelação entre personagens de estratos sociais distintos, podemos considerá-la um personagem da Idade Moderna ao demonstrar uma visão orgânica da sociedade que se transforma para adaptar-se à nova classe emergente, a burguesia. Entretanto, é ambígua porque, se por um lado conspira contra Calisto, incentivando os criados à luta entre classes e organização social, por outro, conquista a sua confiança como mediadora amorosa.

O personagem Celestina se constrói no discurso quando persuade seus interlocutores, dialogando com as intervenções de suas réplicas. Recorre às ferramentas de linguagem, ao poder de agir sobre as pessoas dos vários estratos sociais na cidade, graças aos reconhecidos feitos do passado e à promessa de dinheiro, ponto vulnerável de Sempronio, seu principal aliado:

Celestina - Calla, loquillo; que parte o partezilla, quanto tú quisieres te daré. Todo lo mío es tuyo. Gozémonos y aprovechémonos, que sobre el partir nunca reñiremos. Y también sabes tú quánta más necesidad tienen los viejos que los moços, mayormente tú que vas a mesa puesta. (V, Cena 2, p. 242)

Sempronio não é um aliado fácil de ser persuadido porque, apesar de sua juventude, apresenta as mesmas características da velha: é ganacioso, mesquinho, avarento, além de conhecer bem o éthos efetivo da sua interlocutora:

Sempronio.(Aparte) — “ ¡O lisonjera vieja! ¡O vieja llena de mal! ¡O cobdiciosa y avarienta garganta! También quiere engañar como a mi amo, por ser rica. ¡Pues mala medra tiene! ¡No le arriendo la ganacia! Que quien con modo torpe sube en lo alto, más presto cae que sube. ¡O qué mala cosa es de conocer el hombre! Bien dizen que ninguna mercaduría ni animal es tan difícil. ¡Mala vieja falsa es ésta! ¡El diablo me metió con ella! Más seguro me fuera huyr desta venenosa bívora que tomalla. Mía fue la culpa; pero gané arto, que por bien o mal no negará promessa.” (V, Cena 2, p. 243)

Quando reconhece em Celestina a cobiça, a ganância, a associa com o diabo, a compara com uma víbora, Sempronio, revoltado com a velha, profetiza com esse aparte - recurso estilístico próprio do teatro, empregado quando um ator diz em cena, como se estivesse falando consigo ou somente com o público e 
não fosse ouvido pelos demais personagens — o que está por vir: "bien o mal no negará promessa", a promessa de vingança. 


\section{A CONSTRUÇÃO DE CELESTINA}

Pasos oyo, acá descienden. Haz, Sempronio, que no los oyes. Escucha y déxame hablar lo que a mí y a ti conviene [...] No me congoxes ni me importunes; que sobrecargar el cuidado es aguijar el animal congoxoso. Assí sientes la pena de tu amo Calisto, que parece que tú eres él y él tú, y que los tormentos son en un mismo subjeto. Pues cree que yo no vine acá por deixar este pleyto indeciso, o moriré en la demanda. (I, Cena 8, p. 158)

Celestina faz um aparte fingindo não ser ouvida por Calisto e Pármeno para construir sua imagem diante deles. 


\section{Introdução}

Como vimos no primeiro capítulo, o de como a construção do personagem Celestina se dá não somente no seu discurso, mas também se constrói em função da intervenção do razoamento do outro, daremos seguimento no segundo capítulo à análise das ferramentas de Rojas para montar o personagem Celestina no seu contexto. Além das características físico-psicológicas, a construção de Celestina inclui os elementos utilizados na composição do seu discurso. Nesses elementos encontramos os argumentos que servem de base para a construção de sentido do discurso. Esses argumentos priorizam a busca da imagem que os demais personagens fazem dela e a sua refração ${ }^{28}$, isto é, as várias interpretações que o discurso toma em função do objeto alvo, da sua intenção persuasiva, diante dos seus interlocutores.

Este capítulo visa analisar as proposições defendidas por Celestina, especificando os argumentos que as sustentam, legitimam e viabilizam e quais são refutadas no éthos discursivo. A velha e experiente Celestina é movida pela função de alçancar seu objetivo: ganhar dinheiro para sobreviver e manter seus vícios, como o prazer à mesa. Portanto, temos um capítulo de suma importância, pois nele ora se fundem ora se chocam as teses de construção do discurso com as do personagem. Das suas inúmeras características, a velhice é a que lhe confere maior poder diante dos demais personagens com base na tópica que, sendo mais experiente, sabe o caminho para alcançar o amor e a fortuna. Tópica esta que, no capítulo seguinte, o da deconstrução do personagem no seu discurso, será desmistificada.

Sob a dimensão estética investigamos os recursos expressivos e as estratégias utilizadas pelo personagem - dialogicamente autor e personagem formam um conjunto ressonante - para sensibilizar e atrair seu auditório

${ }^{28}$ Faço uso de um conceito da Física que Bakhtin (1934-1935/1998:87) toma como imagem didática para construir a intenção, a orientação de um discurso a respeito de um objeto é como um raio que, refratado pelo meio de discursos alheios, de apreciações e de entoações através do qual ele passa ao dirigir-se para o objeto, cria um jogo vivo e inimitável de cores e luzes nas facetas da imagem. Em outras palavras, a refração é um fenômeno que ocorre quando um discurso sobre um objeto, apesar de já orientado de uma determinada maneira, ao encontrar outros discursos, apreciações e entoações passa a permitir, por exemplo, que outras interpretações dele possam ser possíveis, fazendo surgir nele novas "cores". 
particular e, consequentemente, alcançar a adesão para os seus interesses. O fenômeno estético desencadeia reações emocionais nos interlocutores. Celestina, como sujeito da enunciação, impressiona seu auditório, o toca e atua, por um lado, na transformação de seus juízos de valor e, por outro, permite expressar suas paixões no discurso. Graças a esse paradoxo encontramos no razoamento do personagem dois estilos linguísticos e expressivos: por um lado, o culto latinizante, o elegante léxico e sintaxe repleta de citações e reformulações clássicas livrescas e, por outro, o popular, o coloquial, cheio de refrães e provérbios de opinião pública e senso comum. Em especial, analisamos uma das reformulações textuais presentes no primeiro texto do corpus tendo como base a segunda carta de Sêneca a Lucílio sobre a diversidade da leitura porque é citada pelo personagem.

Analisamos também, sob a dimensão ética, como Celestina constitui, por um lado, legitimidade e credibilidade como enunciadora para conquistar a confiança dos demais personagens. Verificaremos como, por outro lado, a sua palavra pode ser enganosa, pervertida e desvirtuada e, ao contrário de ser um instrumento para o conhecimento da essência do ser humano, passa a ser uma ferramenta da falácia que promove a privação das relações humanas.

\section{O éthos discursivo de Celestina}

A construção de um personagem no processo discursivo nos leva à análise do éthos de Celestina como enunciadora. Segundo Amossy (2005:9), "todo ato de tomar a palavra implica a construção de uma imagem de si”. Para construir tal imagem, Celestina, no momento do discurso, deixa marcas dessa imagem: seu estilo expressivo, sua voz e corporalidade, sua visão de mundo e conhecimento sobre determinados assuntos e as suas escolhas linguísticas que permitirão ao auditório, o particular e o universal, realizar a construção da sua imagem como enunciadora.

O termo éthos diz respeito a textos orais e escritos, nos quais enunciadores como Celestina e destinatários como os criados e os nobres oferecem uma imagem de si através do discurso. Assim, dizer que os participantes do discurso criam uma imagem de si através dele significa também afirmar que o discurso carrega as marcas da enunciadora e dos destinatários, entendidos aqui como aqueles que interagem no processo discursivo. Tanto as imagens da velha 
alcoviteira como as dos seus destinatários agem no campo discursivo, para ser parte constituinte do processo enunciativo. À construção dessa imagem de si no discurso convencionou-se chamar de éthos.

Para discorrer sobre o éthos de Celestina retomamos alguns conceitos da tradição antiga, focalizando principalmente na teoria de Aristóteles, o responsável por sistematizar a Retórica como a arte da persuasão. Foi com o filósofo grego que o conceito de éthos foi colocado como ponto fundamental para o exercício de persuasão.

Segundo Aristóteles, há três tipos de provas empregadas pelo orador para persuadir seu auditório: o caráter do orador (éthos), as paixões despertadas nos ouvintes (o páthos) e o próprio discurso (o lógos). Durante o processo discursivo o ouvinte se deixa convencer pelas três provas.

O páthos é, segundo Aristóteles, a representação dos sentimentos do próprio auditório — os principais destinatários Sempronio, Pármeno, Calisto e Melibea. Para convencer seu auditório particular a aderir aos seus propósitos, Celestina impressiona, seduz e fundamenta os argumentos na paixão para aumentar seu poder de persuasão. Dessa forma, o páthos liga-se ao ouvinte, sobre o qual recai a carga afetiva gerada pelo lógos do orador. Este último, por sua vez, sendo o discurso, convence, por si mesmo, pelos argumentos utilizados em situação de comunicação concreta. O lógos pode ser ornamental, literário e argumentativo como o da mediadora amorosa. O tipo de argumento que ela usará vai depender da situação comunicativa concreta na qual se insere. Dessa maneira, Meyer (1994, p. 43) nos esclarece:

O orador é simbolizado pelo éthos: a sua credibilidade assenta no seu caráter, na sua honorabilidade, na sua virtude, em suma, na confiança que nele se deposita. $O$ auditório é representado pelo páthos: para convencê-lo é preciso impressioná-lo (...). Resta enfim, a terceira componente, sem dúvida, mais objetiva: o lógos, o discurso.

O éthos, portanto, está ligado a Celestina, ao seu caráter, à sua virtude, na confiança que ela possa gerar nos criados e nos ricos. O caráter de Celestina constituirá ponto importante na persuasão, pois, segundo Aristóteles (1998:49):

Persuade-se pelo caráter quando o discurso é proferido de tal maneira que deixa a impressão de o orador ser digno de fé. Pois acreditamos mais e bem mais depressa em pessoas honestas, em todas as coisas em geral, mas, sobretudo nas de que não há conhecimento exacto e que deixam margem para dúvida. 
Contudo, sob a dimensão ética, Aristóteles afirma que a confiança do auditório no orador reveste-se de maior importância "sobre aquelas coisas em que não há possibilidade de se ter certeza e que deixam lugar a dúvidas" (ROHDEN, 1997: 90). Nesse sentido, enquanto Celestina mantém a imagem de credibilidade, é a enunciadora dos discursos eficazmente persuasivos. O éthos aristotélico não pode ser compreendido isoladamente do páthos e do lógos no processo retórico; no entanto, Aristóteles reafirma que o éthos constitui praticamente a mais importante das provas. Meyer (1994:49-50) declara:

Páthos, lógos e éthos encontram-se sem que possamos nunca delimitá-los com precisão. A autojustificação implica argumentos (lógos), mas também o ter em conta o outro (páthos) a quem se quer agradar para ser aceito ou a quem se quer manipular (éthos).

Assim, na concepção aristotélica, o éthos será o caráter de Celestina representado através do discurso, da imagem de si criada com a intervenção do discurso do outro e desempenhará um importante papel na persuasão. Contudo, o éthos para Aristóteles, não equivale propriamente ao caráter real do orador.

Maingueneau (2006) com a Nova Retórica vai mais além da retomada do conceito aristotélico de éthos como a imagem de si no discurso ao analisar as imagens criadas pelos enunciadores no discurso, baseando-se não somente em situações de eloquência judiciária ou em enunciados orais, mas se estendendo a todo e qualquer discurso, mesmo àqueles presentes no texto escrito.

A noção de éthos permite refletir sobre o processo mais geral da adesão dos sujeitos a certa posição discursiva. Retomando a ideia aristotélica de que o éthos é construído na instância do discurso, Maingueneau (2005) afirma que não existe um éthos preestabelecido, mas sim um éthos construído no âmbito da atividade discursiva. Assim, a imagem de si é um fenômeno que se constrói dentro da instância enunciativa, no momento em que o enunciador toma a palavra e se mostra através do seu discurso. Barthes apud Maingueneau (2005:70) define, então, o éthos, da seguinte maneira:

São os traços de caráter que o orador deve mostrar ao auditório (pouco importando sua sinceridade) para causar boa impressão: são os ares que assume ao se apresentar (...). O orador enuncia uma informação e ao mesmo tempo diz: eu sou isso e não aquilo. 
Esta pesquisa coloca em destaque a característica paradoxal do personagem Celestina. Se por um lado é ambiciosa, astuta, habilidosa na arte de enganar e convencer, avarenta, demoníaca porque vive dos vícios, das paixões proibidas e se aproveita das fragilidades morais dos demais personagens, por outro é verossímil por excelência no sentido de que sua existência se justifica à medida que aquela sociedade urbana renascentista necessita dos seus serviços para satisfazer seus vícios e dar vazão às suas debilidades morais. Gurza (1977:302) afirma que Celestina é um personagem que "tipifica la ambiguedad misma", seja pela sua ambiguidade polifônica, seja por seus vários ofícios que, ao mesmo tempo em que lhe fortalece diante dos demais personagens, a coloca em situações de fraqueza, insegurança, dúvidas, angústia e medos. Essa combinação de sentimentos adversos lhe confere verossimilhança com um ser humano como outro qualquer. Ela é o personagem mais velho da obra, característica que lhe permite ter mais experiência e conhecimento da natureza e das paixões humanas que os demais para, inclusive, conduzir o diálogo segundo as suas conveniências. Os demais personagens perseguem hierarquicamente o amor e a fortuna, ela persegue prioritariamente os meios de como sobreviver.

O éthos discursivo de Celestina desperta várias questões de afetividade tanto no auditório universal quanto nos seus destinatários, o auditório particular. As características desse éthos contribuem para a negociação e para a adesão dos espíritos, como a credibilidade e a confiança na sua experiência adquirida ao longo da sua trajetória de vida e que constituem o éthos pré-discursivo ${ }^{29}$. A conquista da velha ao longo dos experientes anos é fruto das relações de dependência e necessidade de todas as castas sociais do curandeirismo, da mediação amorosa, da arte de perfumismo e de todos os demais ofícios pelos quais é reconhecida na cidade. O espaço urbano é o lugar ideal na época para que se desenvolva a cenografia, pois ali além de se encontrarem todos os tipos sociais, se instala a incipiente burguesia. E é inspirado nessa burguesia que o éthos discursivo de Celestina se constitui ao escolher as ferramentas expressivas que ocultem seu afã por dinheiro.

${ }^{29}$ Segundo R. Amossy (2000), a imagem pessoal do orador é feita a dois níveis: ao nível pré-discursivo, a que chama "ethos préalable" ou "ethos pré-discursif", e ao nível discursivo, que designa como éthos discursivo. 
Mais além do rastro das comédias humanísticas temos em La Celestina as relações amorosas como tema central entre os personagens que representam as diferentes classes sociais urbanas, como os nobres apaixonados, os pais representantes da recém-surgida burguesia, criados, prostitutas, alcoviteiras etc. Cada um desses estereótipos cobra relevo individualizado como personalidades independentes, com paixões e interesses próprios sob a visão de um autor converso em um ambiente universitário. A importância de se salientar esse ambiente está em que o éthos discurso também está presente na voz e na corporalidade daquele orador que lia publicamente a obra como uma prática universitária, imitando os estados de ânimo e o modo de falar dos personagens através de exercícios escolares com os quais se aprendia retórica, poética e gramática e se educava o espírito pela filosofia moral, se dava a leitura ou a recitação de textos como La Celestina.

Sobre o estudo de leituras de obras, Roland Barthes (1987: 127) propõe que a análise do texto se detenha em três níveis: (a) enunciação, (b) enunciado e (c) significação. A enunciação na obra se dá através das falas dos personagens como em um texto com características teatrais como La Celestina, por exemplo —, pois são elas que informam ao leitor o que está ocorrendo na cena. A voz do enunciador do discurso, ideologicamente orientada, não se faz presente no texto diretamente, mas podemos notar sua presença, disseminada nas vozes dos personagens - é através da conjunção de determinado grupo de vozes que podemos observar, implicitamente, a voz e a orientação do autor insinuar-se.

A elaboração argumentativa de Celestina segue algumas estratégias. A argumentação é o recurso presente em qualquer discurso e por meio dela se estabelece o jogo da interlocução marcado pela busca do outro. Segundo Vigneaux (1976), por meio da argumentação, pretendemos agir sobre o outro, transformar nosso interlocutor e assim o faz de modo incessante Celestina sobre seus interlocutores. O caso que nos chama mais a atenção é o conjunto de estratégias expressivas na argumentação para corromper Pármeno e torná-lo seu aliado.

A argumentação de Celestina com o criado reestrutura as três funções primárias presentes em todo processo comunicativo, estabelecidas por Buhler (1934): exprimir quem sou, agir sobre o outro e descrever o mundo. Em essência, o discurso argumentativo tem sua fundamentação no apelo da alteridade, ou seja, 
para que aconteça é preciso considerar a reação de nosso(s) interlocutor(es) aos argumentos que utilizamos. Para exprimir o efeito de sentido que deseja, Celestina confia como favorável o que seus interlocutores já conhecem sobre o seu passado porque lhe garante credibilidade na sua autoridade e experiência adquirida ao longo da vida. Assim, age sobre o outro conhecendo seus pontos de vulnerabilidade, adequando com alteridade seu discurso às distintas situações que se apresentam.

Nesse sentido, Breton (1999:64) sinaliza que "argumentar é mais do que simplesmente conceber um argumento. É também, mais globalmente, comunicar, dirigir-se ao outro, propor-lhe boas razões para ser convencido a partilhar de uma opinião". Portanto, a argumentação atua por meios discursivos, provocando uma ação sobre o espírito dos ouvintes que se objetiva transformar, sendo um processo que envolve uma dinâmica interpessoal complexa (cf. Perelman \& OlbrechtsTyteca, 2002). A contínua adaptação do discurso de Celestina a cada interlocutor em situações às vezes adversas lhe propicia um éthos discursivo modalizador de sentidos.

Quando observamos a linguagem de Celestina em sua função argumentativa, detectamos o modo como ela, enquanto interactante, organiza suas falas para conduzir os destinatários - Sempronio, Pármeno, Calisto, Melibea e as prostitutas — a determinada conclusão: a velha sabe como e pode realizar nossos desejos. Isso também implica dizer que um discurso argumentativo tem como objetivo a adesão do destinatário a um dado ponto de vista, constituindo-se em um processo de negociação que envolve a possibilidade de ocorrerem contraargumentos. Por isso os destinatários negociam com Celestina: Melibea reage mal ao ouvir o nome de Calisto e depois a procura para revelar seu amor por ele, Pármeno intercede contra ela para defender Calisto dos seus poderes e depois pede que interceda em relação ao seu desejo por Areúsa, e Sempronio exige sua parte do negócio em dinheiro. Dessa maneira, argumentar é empreender a busca pelo acordo, o que pode acarretar divergências de opiniões. A oposição de pontos de vista é constitutiva do discurso argumentativo, o que significa dizer que argumentar é também polemizar (cf. Aquino, 1997).

Apesar da possibilidade de que surgirem polêmicas, não devemos restringir a argumentação somente às situações discursivas propensas ao confronto. A este respeito, Aristóteles já identificava, em sua Retórica, um gênero 
oratório, denominado epidíctico, que não versava sobre matérias controvertidas e que não visava à adesão de um auditório. Tal gênero "apresentava um discurso ao qual ninguém se opunha, sobre matérias que não pareciam duvidosas e das quais não se via nenhuma consequência prática. (...) Tratava-se o discurso como espetáculos de teatro ou competições atléticas, cujo objetivo parecia ser pôr em evidência os participantes" (Perelman \& Olbrechts-Tyteca, 2002:54). Assim o fez Celestina em várias situações como quando elogia o corpo de Areúsa com o intuito de convencê-la a deitar-se com Pármeno; quando oferece seus serviços de embelezamento a Lucrécia, criada de Melibea, para mantê-la como facilitadora do acesso à casa da sua ama, e quando discursa como um médico que tem a cura para as dores de amor de Melibea.

As falas de Celestina resultam de uma atividade interpessoal desenvolvida entre pelo menos ela e um ou mais personagens em situação face a face, dentro de uma configuração contextual de que fazem parte os entornos espaço-temporal e histórico-social que os unem. Entretanto, são gritantes as diferenças de grau de manifestação da coprodução discursiva de Celestina e de seus interlocutores, segundo o caráter mais ou menos dialógico da conversa. No diálogo oratório na obra temos uma construção conversacional em que a dialogicidade apresenta-se em grau menor, ou seja, mais assimétrica, porque apenas a interlocutora Celestina tem o maior tempo de turno de voz, especialmente nas suas conversas com Pármeno. É uma variação deste discurso em que longas intervenções são interrompidas por curtas réplicas. Suas considerações teóricas são acompanhadas por sentenças, refrães e exemplos que marcam o tom doutrinário-moralizante de fundo ideológico do autor e do personagem que se individualiza por mostrar seu juízo de valores. Também os elementos não verbais do discurso interferem na negociação para que a enunciadora consiga ou não o acordo com os seus destinatários como a presença em cena, gestos, olhares, entoação, os momentos de silêncio e duração das pausas.

Brait (1993: 194) afirma que, a partir de uma abordagem textual-interativa, podemos estudar, nos diálogos, as relações interpessoais estabelecidas graças à maneira como esse evento discursivo está organizado. Para tanto, é preciso observar: 
gestualidade, expressão facial etc., permitem uma leitura dos pressupostos, dos elementos que mesmo estando implícitos se revelam e mostram a interação como um jogo de subjetividades, um jogo de representações em que o conhecimento se dá através de um processo de negociações, de trocas, de normas partilhadas, de concessões.

O discurso de Pármeno com Calisto contra Celestina é o elemento motivador para que Celestina invista sobre ele o seu poder de persuasão porque encontra uma posição antagônica que pode prejudicar seus planos. Portanto, a construção do discurso de Celestina é motivada pelo discurso que contraria o seu. É no discurso do seu antagonista que ela cria o seu discurso que deve ser persuasivo para atraí-lo a seu favor. E, em caso de ainda não alcançar seus objetivos, em um próximo passo, a enunciadora procura conhecer as vulnerabilidades do seu destinatário para contra argumentar. Essa flexibilidade de adaptação do discurso da enunciadora ao seu destinatário é uma das principais características apresentadas pelo éthos de Celestina.

A análise do éthos do personagem, sobretudo a sua maneira de ser e de dizer $^{30}$, confirma que o emprego das várias técnicas argumentativas é a sua principal função na obra. Nela aparece a excelência do discurso direto sob a forma de diálogo, embora também se destaquem os monólogos — quando a deliberação íntima do éthos fala consigo mesma. A presença quase que exclusiva do diálogo na obra corrobora com o que o professor Rauen ${ }^{31}$ afirma: "uma discussão que visa à melhor solução para um problema polêmico e que leva a uma conclusão inevitável e universalmente aceita". Ele afirma também que o debate, contrariamente ao diálogo, "consiste na luta em defesa de convicções estabelecidas e opostas, no qual cada um usa argumentos favoráveis aos seus objetivos e refuta o alcance daquilo que não lhe é favorável". Sobre o diálogo na obra, Rauen acrescenta que:

${ }^{30}$ Segundo Maingueneau (1995:146), “a maneira de dizer remete a uma maneira de ser” e no etos literário há um "enredamento intrincado" entre "uma determinação social do corpo e uma maneira de dizer".

31 Comentário do prof. Dr. Fábio José Rauen na sua resenha do "Tratado da Argumentação de Perelman e Olbrechts-Tyteca" para Ágora (Caçador), v.4, n. 2, p.175 in br.geocities.com/unigalera1/perelman.doc sobre a escolha da forma do diálogo para a argumentação (acesso julho de 2009). 
[...] dificilmente chegamos a uma discussão sem defender pontos de vista e sem nos convencermos que a vitória do nosso ponto de vista é o triunfo de uma causa justa. Por outro lado, consiste numa distinção de extremos que delimitam diálogos habituais, dentro dos quais a verdadeira argumentação ocorre. Aquele que questiona a si mesmo encarna simultaneamente o orador e o auditório universal — nós, leitores - , uma vez que ele não pode deixar de ser sincero consigo mesmo. Nunca devemos esquecer que ao sermos convencidos, somos vencidos por nós mesmos, pelas nossas ideias. Quando somos persuadidos sempre o somos pelos outros. Assim, um acordo consigo mesmo é uma espécie de acordo com os outros e a análise de como argumentamos com os outros é parâmetro para conhecermos a análise de nós mesmos. (1997:175)

O discurso sob a forma de diálogo em La Celestina permeia as escassas ações que se desenvolvem em um ritmo lento cujo tempo é linearmente explícito, embora também apareça o tempo implícito mais longo. Quanto ao gênero, entre os críticos não há convergência: há teóricos que a consideram como uma comédia humanística, outros como um romance dialogado ou uma obra de teatro para não ser representada.

As primeiras edições de La Celestina levavam no título o nome dos personagens Calisto e Melibea - primeiro Comédia e depois Tragicomédia de Calisto e Melibea - porém a estória de amor entre os jovens nobres perdeu o protagonismo para a persuasão do personagem pobre e velha, a Celestina, precisamente porque os personagens literários adquirem vida própria e transcendência à margem da intenção do autor e da obra. Celestina chegou a ser mencionada como personagem real e alcançou tal poder de sugestão que reorientou a interpretação da obra. Prova disso foi a decisão dos impressores em atender à demanda dos seus leitores: que a obra levasse o nome da protagonista, a que é o eixo da união amorosa entre todos os demais personagens, Celestina. S. Gilman (1978:31) confirma o crescimento do personagem na obra: Sólo la voz autónoma y consecuente de Celestina se enseñora de la obra, imponiendo una unidad que va a reflejarse en el título.

O mesmo autor, Gilman (1978:33), coloca que Fernando de Rojas alcançou a "alta perfección”, através de vozes que parecem autônomas: “[...] los interlocutores y particularmente esa gran maestra del lenguaje hablado, Celestina, se apoderan de La Celestina, pareciendo - en una especie de apoteosis pirandeliana - como si fueran sus autores.

O personagem Celestina se apodera da obra de tal maneira que parece fornecer ferramentas para o autor pôr em prática as teorias retóricas sobre argumentação persuasiva com vista à adesão consciencial dos seus interlocutores, 
em que é preciso ter, além do domínio das técnicas de linguagem, apreço por esta adesão. Contudo e apesar dessas ferramentas, o autor é consciente de que não basta escrever ou falar, mas também é fundamental ser lido e ouvido. Para prover essas ferramentas, Celestina ouve, reconhece e interpreta os desejos dos seus interlocutores. $\mathrm{Na}$ cena anterior ao nosso corpus temos um bom exemplo disso: depois do seu primeiro encontro com Calisto a velha ouve Pármeno insuflar contra ela às escondidas ao seu amo: “[...] parlan lo que éstos fingidamente han dicho, en cuyas falsas palabras pones el fin de tu deseo." (1, Cena 8, p.159)

A astuta percepção do seu opositor leva Celestina a reconhecer em Pármeno um criado fiel a seu amo que, além de adverti-lo, tenta convencê-lo de que não deve confiar nela. É essa característica inicial do criado que a leva a traçar uma estratégia de persuasão para atraí-lo a seu favor: ela mesma se incumbirá de fazer com que Pármeno se volte a seu favor no negócio com Calisto:

Déxame tu a Pármeno, que yo te le haré uno de nos y de lo que hoviéremos, demosle parte; que los bienes, si no son comunicados, no son bienes. Ganemos todos, partamos todos, holguemos todos. Yo te le haré manso y benigno a picar el pan en el puño y seremos dos a dos y, como dizen, tres al mohíno. (1, Cena 8, p.159-160)

Nesse diálogo com Sempronio a velha permite que saibamos que ela mente o tempo todo com a intenção de enganar a todos: não dividirá os ganhos do negócio entre seus sócios embora os faça acreditar que sim através de recursos retóricos. Ela emprega vários artifícios para transmitir um efeito de verdade quando coloca os criados ao seu lado como parceiros. Primeiro, coloca Sempronio no mesmo nivel que ela e anseia o mesmo para Pármeno: "uno de nos". Emprega primeira pessoa do plural para os incluir igualmente nos negócios: "ganemos", "partemos" e "holguemos". Segundo, a repetição de "yo te le haré..." faz com que Sempronio confie na sua persuasão de experiente sócia mais velha. Terceiro, a escolha do léxico "manso" e "benigno" nos remete a um animal a ser domesticado e que agirá para o próprio bem dos seus donos domadores. E, para terminar, a velha escolhe um dito popular "a picar el pan en el puño y seremos dos a dos $y$, como dizen, tres al mohíno": não são mais dois sócios e sim três. "Como dizen" lhe dá respaldo pelo senso comum. 


\section{O processo de corrupção de Pármeno - uma análise do discurso}

Selecionamos no corpus um trecho do diálogo entre Celestina e Pármeno no momento seguinte ao que ela ouve, às escondidas, Pármeno investir contra ela a Calisto. Então, ela se sente desafiada a persuadi-lo antes mesmo que o criado revelasse de quem era filho e, assim, o reconhecesse como seu afilhado. Contudo, reconhecerá mais tarde o ponto frágil, o qual usará contra ele: “[...] tan puta vieja era tu madre como yo! ¿Por qué me persigues, Parmenico?”.

Ao descobrir a verdadeira identidade do criado, Celestina tem nas mãos uma ferramenta de coerção para persuadir Pármeno a ser seu aliado no negócio com Calisto. Segundo Perelman (1996), as premissas da argumentação são as teses sobre as quais há um acordo. Nesse sentido, o discurso de Celestina apoia-se no forte argumento de autoridade de uma mãe que aconselha seu filho sob três premissas essenciais:

1. Calisto é amo - faz-se a crítica social contra o status do seu oponente.

2. Sempronio é criado como Pármeno - a aproximação ao seu semelhante de igual classe social deve-se a que Sempronio já era o principal aliado de Celestina no negócio para tirar dinheiro de Calisto.

3. Pármeno deve ser amigo de Sempronio, tão criado quanto ele, e não de Calisto, de uma classe social superior à de Pármeno.

Essas três premissas reunem mais um exemplo de paradoxo retórico na obra: Celestina defende uma posição que, por um lado é reprovável porque o criado terá que romper com a qualidade de ser fiel ao amo, porém, por outro lado, é recomendável que ele se una ao outro criado, uma vez que são do mesmo status social. Esse parodoxo retórico do discurso da velha alcoviteira demonstra a coexistência de contrários que, unidos, a coloca em risco porque alimenta os vícios que os seus antagonistas usarão contra ela própria.

A velha engana ao tentar confundir seu auditório, universal e particular, leitores e personagens, com o efeito de verdade: Sempronio é um criado infiel, não é amigo a não ser do dinheiro e, por isso, é o maior oponente de Celestina. Ao atrair Pármeno para o lado de Sempronio, ela aumenta a força dos seus 
adversários. Assim, Celestina especula sobre sua própria função retórica na obra por uma espécie de contradição dialética: ela explora a instável hierarquia de valores dos seus competidores que, ora valorizam mais a luxúria - as relações sexuais com as prostitutas - , ora valorizam mais a ganância e a cobiça — não se importam em trair quem quer que seja, o seu amo ou a própria sócia.

Diante da complexidade do discurso de Celestina, fazemos aqui um descongelamento do texto para estudar as partes do diálogo que compõem o primeiro corpus desta pesquisa. Dividimos este discurso em cinco partes conforme Celestina faz a mudança da sua estratégia para conquistar a adesão de Pármeno. Como se trata de um diálogo oratório, discursivo e retórico de longo parlamento por parte da enunciadora sem interferência da réplica do seu interlocutor, constatamos a inferioridade de Pármeno diante de Celestina. Essa submissão do criado se deve à dimensão ética do discurso da velha, a que constitui legitimidade e credibilidade como eficaz enunciadora para conquistar a confiança dos seus interlocutores.

A primeira parte é a que corresponde à fase introdutória que se caracteriza pela apresentação do sujeito principal desse diálogo, Pármeno, que é o próprio interlocutor, no desejo de torná-lo seu aliado:

Celestina. “- ¡Mala landre te mate! ¡Y cómo lo dize el desvergonçado! Dexadas burlas y pasatiempos, oye agora, mi fijo, y escucha: que aunque a un fin soy llamada, a otro só venida; y maguera que contigo me aya fecho de nuevas, tú eres la causa."

A segunda parte do diálogo se caracteriza pela primeira estratégia de Celestina para a persuasão de Pármeno, que é o apelo afetivo à memória do interlocutor:

Hijo, bien sabes como tu madre, que Dios aya, te me dio viviendo tu padre, el qual, como de mi te fueste, con otra ansia no murió sino con la incertidumbre de tu vida y persona, por la qual absencia algunos años de su vejez sufrió angustiosa y cuydadosa vida. Y al tiempo que della passó, embió por mí y en su secreto te me encargó y me dixo, sin otro testigo sino Aquel que es testigo de todas las obras y pensamientos, y los corazones y entrañas escudriña, al qual puso entre él y mí que te buscasse y allegasse y abrigase, y quando de complida edad fueses, tal que en tu vivir supieses tener manera y forma, te cubriesse a dónde dexó encerrada tal copia de oro y plata que basta más que la renta de tu amo Calisto. Y porque gelo prometí y con mi promesa llevó descanso y la fe es de guardar más que a los vivos a los muertos, que no pueden hazer por sí, en pesquisa y seguimiento tuyo yo he gastado asaz tiempo y quantías hasta agora, que ha aplazido a Aquel que todos los cuydados tiene y remedia las justas peticiones y piedosas obras endereça, que te hallase aqui, donde solos ha tres dias que se que moras. Sin duda dolor he sentido, [...] 
A terceira parte do diálogo neste corpus corresponde à estratégia do exemplum ex contrariis com o emprego de imperativo negativo e orações unidas por conjunções coordenativas copulativas. Tomando como modelo a Segunda Carta de Sêneca ${ }^{32}$ a Lucílio sobre a diversidade na leitura, a influência da cultura humanística de Rojas o leva a uma reformulação do texto clássico:

[...] porque has por tantas partes vagado e peregrinado que ni has havido provecho, ni ganado debdo ni amistad; que, como Seneca nos dize, los peregrinos tienen muchas posadas y pocas amistades porque en breve tiempo con ninguno no pueden firmar amistad; y el que está en muchos cabos no está en ninguno; ni puede aprovechar el manjar a los cuerpos que, en comiendo, se lança, ni ay cosa que más la sanidad impida que la diversidad y mudança y variación de los manjares; y nunca la llaga viene a cicatrizar en la qual muchas melezinas se tientan, ni conualesce la planta que muchas vezes es traspuesta, ni ay cosa tan provechosa que, en llegando, aproveche.

$\mathrm{Na}$ quarta parte do descongelamento proposto ao diálogo verificamos que a estratégia argumentativa é a de aconselhar, fazer perguntas retóricas e o emprego do argumento ad hominem contra Calisto:

\begin{abstract}
Por tanto, mi hijo, dexa los ímpetus de la juventud y tórnate, con la doctrina de tus mayores, a la razón. Reposa en alguna parte. ¿Y dónde mejor que en mi voluntad, en mi ánimo, en mi consejo, a quien tus padres te remetieron? Y yo, assí como verdadera madre tuya, te digo, so las maldiciones que tus padres te pusieron si me fuesses inobediente, que por el presente sufras y sirvas a este tu amo que procuraste, hasta en ello hauer otro consejo mio; pero no con necia lealdad, proponiendo firmeza sobre lo movible, como son estos señores deste tiempo. Y tú, gana amigos, que es cosa durable. Ten con ellos constancia. No vivas en flores. Dexa los vanos prometimientos de los señores: los quales desechan la substância de sus siruientes con huecos e vanos prometimientos. Como la sanguijuela saca la sangre, desagradescen, injurian, olvidan servicios, niegan galardón. ¡Guay de quien en palacio envejece! Como se escrive de la probática piscina, que de ciento que entravan, sanava uno. Estos señores deste tiempo más aman a sí que a los suyos; y no yerran; los suyos ygualmente lo deven hazer. Perdidas son las mercedes, las magnificencias, los actos nobles. Cada uno destos cativan y mezquinamente procuran su interesse con los suyos; pues aquéllos no deven menos hazer, como sean en facultades menores, sino vivir a su ley. Dígolo, fijo Pármeno, porque este tu amo, como dizen, me parece rompenecios. De todos se quiere servir sin merced.
\end{abstract}

A quinta e última parte deste corpus culmina com o objetivo da tentativa de persuasão: o de convencê-lo a ser amigo de Sempronio:

Mira bien, créeme. En su casa cobra amigos, que es el mayor precio mundano; que con él no pienses tener amistad, como por la diferencia de los estados o condiciones pocas vezes contezca. Caso es ofrecido, como sabes, en que todos medremos y tú

${ }^{32} \mathrm{O}$ texto original em latim e as versões em português e espanhol estão nos Anexos. 
por el presente te remedies. Que lo al que te he dicho guardado te está a su tiempo. Y mucho te aprovecharás siendo amigo de Sempronio.

Estabelecidos os critérios da divisão do corpus em partes para a análise, iniciamos pela primeira parte, a fase introdutória do discurso que se caracteriza pela apresentação do tema principal desse diálogo com Pármeno, que é o próprio interlocutor no desejo de torná-lo seu aliado. Dentro do gênero epidítico, Celestina abre seu discurso em tom imponente de ameaça: “ ¡Mala landre te mate! ¡Y cómo lo dize el desvergonçado! Dexadas burlas y pasatiempos, oye agora, mi fijo, y escucha: [...]"

Com caráter e corporalidade de quem tem domínio sobre o futuro, profetiza: "mala landre te mate", que é uma maldição popular, "landre" é um tipo de tumor pequeno. Logo em seguida, ameniza e sinaliza a mudança de tom: "deixadas burlas e pasatiempos", para ser mais objetiva e ir direto ao assunto.

Celestina, que já sinalizara mudança de tom de ameaça diminui a distância entre seu auditório particular, usando tom maternal: "oye agora, mi fijo, y escucha:"; com o uso da pontuação — os dois pontos —, assinala o firme objetivo de introduzir a "causa" do diálogo, palavra por ela usada: "tú eres la causa". Emprega duas conjunções concessivas "aunque" e "maguera" para realçar que ainda que tenha ido a casa de Calisto para negociar a sua intermediação com Melibea, o verdadeiro motivo é o reencontro com Pármeno. O que é absolutamente mais uma falácia da velha, uma rapidez de reflexo para improvisar e aproveitar-se da informação recém recebida do próprio criado porque, até então, ela não o havia reconhecido como filho da prostituta Claudina: “[...] que aunque a un fin soy llamada, a otro só venida; y maguera que contigo me aya fecho de nuevas, tú eres la causa.”

Celestina recorre a dois fortes argumentos: o de analogia com a figura da mãe já falecida e, portanto, o de apelo à afetividade, memória pessoal e religiosidade, traço marcante também naquela época: "Hijo, bien sabes como tu madre, que Dios aya, te me dio viviendo tu padre".

O emprego do vocativo "hijo" se traduz no seu objetivo de aproximação pelo lado afetivo. Quando Celestina diz que em segredo a mãe de Pármeno pediulhe sem outra testemunha que não Deus, novamente abusa do argumento de autoridade, da voz do outro e da religiosidade da época, pois, o que conta a Pármeno são fatos da sua infância, os quais ele não tem como comprovar naquele 
momento; portanto, torna o seu discurso incontestável, além de não deixar sombras de dúvida sobre a confiança da mãe dele por ela, ainda confere legitimidade ao seu discurso:

[...] embió por mí y en su secreto te me encargó y me dixo, sin otro testigo sino Aquel que es testigo de todas las obras y pensamientos, y los corazones y entrañas escudriña, al qual puso entre él y mí que te buscasse y allegasse y abrigase [...]

Por obra da redescoberta e da reabilitação da Nova Retórica pode-se afirmar que Celestina argumenta pelo que considera razoável, provável ou possível de ser. Faz-se um uso prático que não é necessariamente passível de evidência. Quando tenta convencer Pármeno fala de uma herança inverossímil, principalmente se comparada com a do nobre, embora a sua verdadeira intenção seja despertar no ingênuo e fiel criado a cobiça para persuadi-lo a ser seu aliado.

[...] quando de complida edad fueses, tal que en tu vivir supieses tener manera y forma, te cubriesse a dónde dexó encerrada tal copia de oro y plata que basta más que la renta de tu amo Calisto $[\ldots]$

Assim, ela não só despreza o seu oponente Calisto através de uma presunção de verdade, a herança de ouro e prata que ela bem sabe não existir, como também se usa do ataque ad hominem à pessoa do amo para afastá-lo de Pármeno e aproximá-lo do tão criado quanto ele, Sempronio. Celestina faz uso da tópica da velhice como sinônimo de experiência para impor autoridade perante o jovem Pármeno e, conhecedora da psicologia humana, conduzi-lo pelo caminho da ganância ao mencionar a herança de ouro e prata e posteriormente, pelo da luxúria, ao uni-lo a Areúsa.

Celestina induz Pármeno a pensar que, como ela tivesse prometido cuidar dele, sua mãe pode morrer em paz. É o argumento por causa e consequência: a palavra "promessa" revela caráter e corporalidade de autoridade e tom de sinceridade: "Y porque gelo prometí y con mi promesa llevó descanso y la fe es de guardar más que a los vivos a los muertos".

Para dar continuidade a seu discurso, Celestina enaltece os seus próprios feitos, revela a sua noção de valor e explica suas preferências para captar a benevolência de Pármeno em tom de chantagem: “[...] que no pueden hazer por 
sí, en pesquisa y seguimiento tuyo yo he gastado asaz tiempo y quantía hasta agora, $[\ldots]^{\prime \prime}$

Retoma o poder de fiadora e o argumento de autoridade e religiosidade comparando-se a Deus em quem se apóia para legitimar a sua chantagem. As palavras "justas" e "piadosas" fazem de Celestina uma importante fiadora de Deus por excelência ao reencontrar Pármeno: “[...] que ha aplazido a Aquel que todos los cuydados tiene y remedia las justas peticiones y piedosas obras endereça: que te hallase aqui".

Uma vez que não pode contar com o que é do domínio da opinião pública sobre seus sentimentos pessoais, Celestina explora a verdade consentida através da endoxa "sem dúvida". "Sin duda dolor he sentido" visa autovalorizar o seu sentimento de dor: "[...] que te hallase aqui, donde solos ha tres dias que se que moras. Sin duda dolor he sentido".

Celestina deixa transparecer a voz do autor quando faz uma reformulação intradiscursiva explicativa ao inferir o discurso de Sêneca.

[...] has por tantas partes vagado y peregrinado: que ni has hauido prouecho, $\underline{\text { ni }}$ ganado debdo ni amistad; que, como Seneca nos dize, los peregrinos tienen muchas posadas y pocas amistades.

A reformulação intradiscursiva explicativa com base em citações textuais à epístola de Sêneca promove um deslocamento no campo semântico das cartas de Epistulae morales do autor clássico romano, que foram traduzidas ao espanhol e impressas em Zaragoza em 1496. Segundo consta no inventário de Rojas feito após sua morte ele possuía um exemplar em sua biblioteca, o que nos leva a acrescentar que a influência de Sêneca vai mais além das citações, inunda seu pensamento e a atitude diante dos valores como o amor, a amizade e a fortuna. $\mathrm{O}$ autor cita com frequência algumas obras pseudosenequista, como De moribus e Proverbia Senecae, uma compilação de 365 sentenças que foram traduzidas por Fernán Díaz de Toledo em 1444 por ordem de Juan II.

A reformulação da segunda carta de Sêneca a Lucílio sobre a diversidade na leitura ${ }^{33}$ por Rojas carrega uma perspectiva textual-interativa sobre a

${ }^{33} \mathrm{O}$ texto completo encontra-se no Anexo 2: Alia Senecae epistola de varietate lectionis. 
linguagem à medida que o autor assume o texto conversacional como um complexo de atividades linguístico-comunicativas, realizadas interacionalmente, de modo que resulte em uma sequência de atividades de composição em $L a$ Celestina.

O personagem realiza um deslocamento semântico por isotopia, isto é, ao se apropriar do texto alheio, a carta em que Sêneca aconselha Lucílio sobre a aquisição e a escolha do material de leitura, a polifonia de Rojas surge na voz e corpo de Celestina, uma vez que é inverossímil que uma velha prostituta do fim do Renascimento conheça a obra do orador do século IV a.C. e a cita como ferramenta de entrada para também aconselhar Pármeno sobre como escolher suas amizades. Pármeno passa a ser o peregrino de Sêneca, o jovem andarilho que deve seguir a voz da experiência de Celestina, assim como Lucílio lê a carta do seu mestre, para procurar amigos como Sempronio. Essa ambivalência serve para elevar Pármeno da condição de criado à de um discípulo de Sêneca, através do argumento por analogia do exemplo do peregrino - o presente histórico "Séneca nos dize" denota conhecimento e intimidade com o pensador. Celestina compara as poucas amizades dos peregrinos de Sêneca à Pármeno repetindo o deslocamento do campo semântico.

Podemos traçar um paralelo por ambivalência entre a Segunda Carta de Sêneca a Lucílio e o intradiscurso no texto de Celestina como ferramenta de entrada para a reformulação do texto do orador clássico, que serve como modelo do pensamento estoico no Renascimento e da manifestação de Rojas:

\section{Sêneca}

In peregrinatione vitam agentibus hoc evenit, ut multa hospicia habeant, nullas amicitias.

\section{Celestina}

[...] los peregrinos tienen muchas posadas y pocas amistades porque en breue tiempo con ninguno no pueden firmar amistad.

Há um diálogo entre a Carta de Sêneca e a estratégia da velha alcoviteira para persuadir o criado em mais de uma passagem, fato que, além de confirmar as influências da cultura humanista na obra, é empregado como ferramenta de 
argumentação incontestável e indiscutível e, sobretudo, reafirma a voz do autor na fala de Celestina.

Ao exemplo do orador clássico, o emprego de terceira repetição da conjunção coordenativa aditiva "ni" liga, depois, por negação os termos “proveito", "parentesco" e "amizade”, tudo o que ela afirma que Pármeno não terá

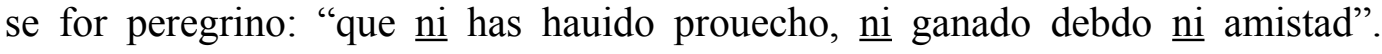
Certamente, para Celestina, peregrino é aquele que muito caminha porque não segue seus conselhos de ser amigo do criado de Calisto.

Celestina explica a ideia de Sêneca com o argumento por causa e consequência através de uma doxa: "el que está en muchos cabos no está en ninguno". Essa frase é reformulada na voz de Celestina, conforme afirma Rojas, “como Séneca nos dize” na Segunda Carta a Lucílio: "Nusquam est qui ubique est", ou seja, quem está por toda parte, não está em lugar algum: "porque en breve tiempo con ninguno no pueden firmar amistad. Y el que está en muchos cabos no está en ninguno".

As duas frases negativas dão início a outra sequência de frases ligadas pela negação "ni" para usar o argumento da controvérsia, recorrendo-se ao uso da conjunção coordenativa copulativa correlativa: nem... nem.

[...] ni puede aprovechar el manjar a los cuerpos, que en comiendo se lança, ni ay cosa que mas la sanidad impida que la diversidad y mudança y variación de los manjares; y nunca la llaga viene a cicatrizar en la qual muchas melezinas se tientan, ni convalesce la planta que muchas vezes es traspuesta; ni ay cosa tan prouechosa, que en llegando aproveche.

Recurso semelhante foi utilizado por Sêneca para demonstrar a seu discípulo o que não deveria fazer. Temos um diálogo entre os dois textos que empregam a mesma estratégia de convencimento de um mestre mais experiente a seu pupilo. A reformulação é nítida na comparação entre os dois discursos, muito embora o deslocamento semântico fosse necessário porque o primeiro compara os peregrinos àqueles que muito leem, que passam os olhos por tudo sem se aprofundar na leitura e o segundo, os compara com àqueles que não tem muitas amizades como as de Sempronio, que está a seu lado:

\section{Sêneca}


Non prodest cibus, nec

\section{Celestina}

corpori accedit, qui statim sumptus

emittitur. 
[...] ni puede aprovechar el manjar a los cuerpos, que en comiendo se lanza.

Nihil aeque sanitatem impedit quam remediorum crebra mutatio.

Non venit vulnus ad cicatricem, in quo crebra medicamenta tentantur.

Non convalescit planta quae saepius transfertur, nihil tam utile est, quo in transitu prosit.
[...] ni ay cosa que mas la sanidad impida que la diuersidad y mudanza y variación de los manjares.

[...] y nunca la llaga viene a cicatrizar: en la qual muchas melezinas se tientan;

[...].ni convalesce la planta que muchas vezes es traspuesta [...] 
Após mostrar o que não deve ser feito e suas consequências, Celestina quer resumir em tom conselheiro: "por tanto," - conjunção conclusiva após uma longa sequência de frases negativas — "mi hijo," — tom de afetividade e argumento de coexistência por hierarquia — “dexa" (uso do imperativo) "los ímpetus de la juventud y tórnate," (imperativo) “con la doctrina de tus mayores, a la razón. Reposa” (imperativo) "en alguna parte": "Por tanto, mi hijo, dexa los ímpetus de la juventud y tórnate, con la doctrina de tus mayores, a la razón. Reposa en alguna parte."

Em seguida, para chamar a atenção do enunciador para aceitar a sua resposta como única, Celestina lança uma pergunta retórica cuja resposta ela mesma dá, apelando à autoridade que lhe foi conferida pelos pais de Pármeno, cuja presunção não pode ser comprovada: “[...] ¿Y dónde mejor que en mi voluntad, en mi ánimo, en mi consejo, a quien tus padres te remetieron?".

Para captar a benevolência de Pármeno e legitimidade, Celestina abusa de considerar-se a representação da figura dos seus pais.

É mantido o tom afetivo e se usa o argumento do exemplo pelo caso particular por analogia à figura da mãe: "Y yo assi como verdadera madre tuya te digo:", que lhe confere a autoridade de mãe.

Celestina quer diminuir a influência da autoridade do amo Calisto sobre Pármeno para aumentar a influência do criado Sempronio, seu principal aliado, sobre ele.

[...] hasta en ello haver otro consejo mío; pero no con necia lealdad, proponiendo firmeza sobre lo movible, como son estos señores deste tiempo. Y tú, gana amigos, que es cosa durable. Ten con ellos constancia.

Pelo raciocínio por analogia, ainda que falsa, a contraposição pela figura da antítese - "volúvel" versus "duradoura" e "amo" versus "amigos" — leva à conclusão de que o amo é volúvel e amigos são duradouros. Celestina utiliza-se do argumento de "falsa analogia", o que consiste no estabelecimento de comparações analógicas que não levam em consideração certos elementos que tornam diferente o raciocínio, estabelecendo, assim, uma conclusão distinta. Esse recurso à "falsa analogia" permite vincular, de modo alegórico, situações que não seriam aceitas como relações cientificamente consistentes e permite relacionar situações que, pelo critério do conhecimento lógico, não poderiam ser efetivamente vinculadas. Não seriam mais que analogias ideológicas. O raciocínio por esse recurso permite relacionar persuasivamente 
várias normas entre si, normas e decisões, decisões com decisões, podendo ainda colocar como analógicos fatos que logicamente devem ser vistos como membros de classes diferentes. É um tipo de falácia que é construído com a ausência, na maior parte das vezes, do processo analógico que não se manifesta no raciocínio exposto no texto. Constata-se uma analogia latente.

Celestina segue sua argumentação recorrendo às passagens da Bíblia e à doxa ${ }^{34}$ que fortalecem seu discurso persuasivo: "Guay de quien en palacio envejece (emprego da doxa, refrão conhecido na época), "como se escrive" (a impessoalidade é mais um recurso para garantir a doxa), "de la probática piscina" (faz um apelo à religiosidade e sugere conhecimentos prévios das passagens bíblicas do cristianismo, com a referência à piscina de poderes curativos em Jerusalém, ao lado do Templo de Salomão, mencionada em São João 5,2), “que de ciento que entravan, sanava uno”.(utiliza um argumento que explica e ratifica a passagem bíblica). "Estos señores deste tiempo" (mais uma vez, a impessoalidade garante o domínio público da opinião e refaz o ataque ad hominem à pessoa de Calisto):

[...] mas aman a sí que a los suyos; y no yerran; los suyos ygualmente lo deven hazer. Perdidas son las mercedes, las magnificencias, los actos nobles. Cada uno destos cativan y mezquinamente procuran su interesse con los suyos; pues aquéllos no deven menos hazer, como sean en facultades menores, sino vivir a su ley.

34 Empregamos a palavra grega doxa na sua acepção mais moderna, que significa o lugarcomum, a idéia compartilhada, a crença comum ou opinião, o que reflete os costumes ou práticas mais do que a opinião pessoal. Essa palavra foi extensivamente utilizada pelos retóricos gregos como ferramenta para formação de argumentos através de opiniões comuns, a doxa (em oposição ao saber verdadeiro,episteme) foi utilizada pelos sofistas para persuadir as pessoas, levando Platão a condenar a democracia ateniense.

A palavra doxa ganhou novo sentido nos séculos III a.e.C. e I a.e.C quando os "setenta" (evdomikonta) sábios em Alexandria traduziram as escrituras hebraicas para o grego. Nessa tradução das Escrituras, chamada de Septuaginta, a palavra hebraica para glória (kabot) foi traduzida para o grego como doxa. Essa tradução das Escrituras Hebraicas foi utilizada pela Igreja primitiva, sendo constantemente citada e utilizada pelos redatores do Novo Testamento. Os efeitos desse novo significado de "doxa" como "glória" é evidenciado pela utilização da palavra em todos os lugares do Novo Testamento e nos serviços de adoração da Igreja Ortodoxa Grega. 
Celestina emprega uma grande estratégica retórica utilizada quando há discordância entre a enunciadora e seu destinatário, o ad rem, que é a maneira de tratar a causa da questão da discussão se mistura à invocação pessoal, o ad homimen. Meyer (2007:50) afirma que quando não se pode ter razão sobre uma questão dada é "tentador fazer voltar o ataque contra a pessoa que defende o ponto de vista oposto". Estratégia utilizada mais de uma vez por Celestina para desqualificar o seu oponente, Calisto, e forçar a aceitação dos seus pontos de vista, pela técnica de ruptura: "Dexa los vanos prometimientos de los señores". Calisto passa a ser seu oponente nessa questão porque ela precisa convencer Pármeno a unir-se a Sempronio para enganar o amo.

Dexa los vanos prometimientos de los señores: los quales desechan la substância de sus sirvientes con huecos y vanos prometimientos: como la sanguijuela saca la sangre: desagradescen, injurian, olvidan servicios, niegan galardón.

A experiente velha volta a empregar o argumento contra a pessoa do amo de Pármeno estabelecendo ofensas que exploram uma circunstância, a hierarquia entre classes sociais, e que o colocam em situação conflitiva diante do seu coenunciador. O argumento ofensivo substituiu a conclusão pertinente ao raciocínio pela desclassificação do homem a quem se pretende imputar determinados vícios ou imperfeições, no caso, o fato de pertencer à classe dos amos e não à dos criados, criando-se uma imagem negativa em torno dele para, dessa maneira, obter também a desclassificação do apoio do amo. Esse tipo de falácia é usado como meio de debilitar os argumentos ou afirmações do contendor, o amo Calisto, e fortalecer indiretamente assim, os seus próprios pontos de vista. Generalizando, podemos afirmar que é factível persuadir falaciosamente ao provocar uma atitude de repulsa a certas afirmações fáticas ou valorativas, induzindo-se a uma atitude também de repulsa em relação às pessoas vinculadas a esses fatos ou opiniões: "los quales desechan la substância de sus siruientes con huecos e vanos prometimientos: como la sanguijuela saca la sangre: desagradescen, injurian, oluidan seruicios, niegan galardón".

Em tom falsamente carinhoso para ganhar a adesão do coenunciador, uma vez que deseja manter a distância de superioridade que a sua experiência lhe confere, novamente agride a face do terceiro em uma ligação de coexistência interação ato/pessoa: "digolo, fijo" (tom afetivo) "Pármeno: porque este tu amo, como dizen" (impessoalidade para garantira autoridade da doxa), "me parece rompenecios" (opinião que agride a face de Calisto, seu oponente): "De todos se quiere servir sin merced." 
[...] Mira bien, créeme. En su casa cobra amigos, que es el mayor precio mundano; que con él no pienses tener amistad, como por la diferencia de los estados o condiciones pocas vezes contezca.

A presença do vocativo "mira bien,", para cativar a atenção para as ligações de coexistência: “créeme: en su casa cobra amigos” (uso do imperativo para aconselhar) "que es el mayor precio mundano: que con el no pienses" (uso do imperativo para aconselhar) "tener amistad, como por la diferencia de los estados o condiciones pocas vezes contezca". Novamente Celestina usa de uma técnica de ruptura com o amo que pertence à classe social que se quer atingir. A crítica social nada mais é que uma ferramenta para convencer Pármeno a ser amigo de Sempronio, um criado tal como ele.

Caso es ofrecido, como sabes, en que todos medremos y tú por el presente te remedies. Que lo al que te he dicho guardado te está a su tiempo. Y mucho te aprovecharás siendo amigo de Sempronio.

Apresenta o argumento de ligação de sucessão entre fins e meios: "Caso es ofrecido, como sabes, en que todos medremos" (argumento conclusivo) "y tú por el presente te remedies" (apelo à ganância) "que lo al que te he dicho, guardado te está a su tiempo. Y mucho te aprovecharás siendo amigo de Sempronio". Celestina fecha o seu discurso concluindo que o meio para que Pármeno saia remediado financeiramente seria a união com Sempronio.

À medida que Celestina visa levar Pármeno a realizar uma ação ou a crer em algo, ela necessita, ao enunciar o seu discurso, que este adquira uma construção linguística capaz de proporcionar ao criado a percepção da sua intenção comunicativa. É preciso, portanto, que seu enunciado seja compreendido por ele. Essa construção linguística do enunciado implica, de acordo com Hilgert (1999:107), “dar forma e organização linguística a um conteúdo, a uma ideia, enfim, a uma intenção comunicativa”. É justamente essa preocupação com o "dizer" que vai evidenciar, no texto dialogado de La Celestina, as atividades de formulação textual, entendidas como uma série de marcas responsáveis pela caracterização específica de sua formulação, às quais Celestina se vê impelida a recorrer para ter sucesso no seu objetivo comunicacional. Nesse contexto, Hilgert (1999: 106) admite que as paráfrases evidenciam uma descontinuidade no fluxo da formulação: ao perceber algum tipo de problema na sua formulação linguística (tais como erros, falhas, busca de palavra adequada, de enunciados mais completos, explícitos ou explicativos, entre 
outros) a enunciadora interrompe a sucessão de enunciados que realiza retomando-o em forma de paráfrase. Em virtude dessa natureza inerente às construções parafrásticas, o autor enquadra tais estratégias, ao lado das correções, como atividades de reformulação textual, haja vista que sempre procedem à reformulação de enunciados anteriores, o que lhes confere caráter metaformulativo. Concebe-se assim o parafraseamento como "uma estratégia de construção textual que se situa entre as atividades de reformulação, por meio das quais novos enunciados remetem, no curso da fala, a enunciados anteriores, modificando-os total ou parcialmente" (Hilgert, 2006, p.275). De acordo com essa perspectiva, "a paráfrase não é, em si mesma, uma propriedade de formulações linguísticas, mas o resultado de uma estratégia cognitivo-discursiva dos sujeitos" (Fuchs, 1994, p. 130131). Temos o exemplo da reformulação do discurso de Sêneca que caracteriza o terceiro segmento desse diálogo entre Celestina e Pármeno - em que somente a velha domina o turno de voz, exemplo de polifonia no discurso quando Rojas se faz presente na voz do personagem.

As várias desqualificações à face do seu oponente, Calisto, e a insistência na tópica do princípio de autoridade de que os velhos, portanto mais experientes, sabem o que é melhor para os jovens formam a base do discurso de Celestina. Consideramos que há uma intenção paródica à moral no recurso porporcionado pela argumentação retórica e pervertida da velha alcoviteira em submeter os jovens à luxúria, à cobiça e à hipocrisia. Também consideramos que se desmistifica a velhice como expressão única de autoridade diante dos mais jovens e se reacende uma reflexão sobre atributos morais como a honestidade e a incorruptibilidade.

Em outras passagens do discurso de Celestina com Pármeno, o "imperativo" de corrupção domina permanentemente: "Desechas el provecho por contentar la lengua", o que equivale a afirmar: "corrómpete y calla." ${ }^{35}$. A velha apresenta o corrupto Sempronio paradoxalmente como exemplo de virtude a ser seguido por Pármeno: "Mira que es bienquisto, diligente, palanciano, buen servidor, gracioso; quiere tu amistad; crecería vuestro provecho dándonos el uno al otro la mano...”.

Para converter Pármeno em seu aliado, Celestina exerce sua influência de modo especial em três assédios, todos baseados na insistência da tópica da experiência da velha no caráter humano em geral e nas inclinações dos jovens. No primeiro encontro, antes de saber que Pármeno é filho de Claudina, antiga companheira de prostituição, ela

\footnotetext{
${ }^{35}$ Maestro in "El personaje nihilista".
} 
se insinua pelo sexual: "la dulçura del soberano deleite" (Ato I, 81). Como Celestina não perde a oportunidade de aconselhar os jovens que vivam intensamente o momento, sob a tópica do carpe diem, além de ter de convencer Pármeno a ser seu aliado na empreitada com Calisto, incentiva o criado a gozar a juventude na sua mais carnal expressão: "el amor es la fuerza motivadora del hombre y del universo":

Has de saber, Pármeno, que Calisto anda de amor quexoso. E no lo juzgues por eso por flaco; que el amor impervio todas las cosas vence. Y sabe, si no sabes, que dos conclusiones son verdaderas: la primera, que es forçoso al hombre amar a la mujer, y la muger al hombre. La segunda, que el que verdaderamente ama es necessario que se turbe con la dulçura del soberano deleyte, que por el Hazedor de las cosas fue puesto, por que el linaje de los hombres perpetuase, sin lo qual perescería. (Ato I, Cena 10, pp. 162-3)

Entretanto, a conversa toma novo rumo quando Celestina descobre de quem Pármeno é filho porque, assim, ela pode contra-argumentar para que ele não influencie Calisto contra ela. Afinal, Claudina, a mãe de Pármeno, fora companheira de Celestina na prostituição. Ela comenta com Sempronio:

\begin{abstract}
Aquí está Celestina que le vido nascer y le ayudó a criar. Su madre y yo, uña y carne. Della aprendí todo lo mejor que sé de mi oficio. Juntas comíamos, juntas dormíamos, juntas havíamos nuestros solazes, nuestros consejos y conciertos. En casa y fuera como dos hermanas, nunca blanca gané en que no toviesse su meytad. Pero no vivía yo engañada si mi fortuna quisiera que ella me durara. ¡O muerte, muerte! ¡A quántos privas de agradable compañía! ¡A quántos desconsuelas por tan enojosa visitación. Por uno que comes con tiempo, cortas mil en agraz. Que, siendo ella viva, no fueran estos mis passos desacompañados. ¡Buen siglo aya, que leal amiga y compañera me fue! (Ato III, Cena 1, pp.194-5)
\end{abstract}

Logo Celestina tenta atraí-lo pela cobiça. O jovem sente a tormenta da tentação: "No sé qué haga, perplejo estoy" (Ato I, 86), mas resiste. Até que volta à tentação sexual concreta, mencionando o nome de Areúsa. Quando fracassam as tentações da riqueza e da carne, usa-se do poder diabólico: "Pármeno, me despido de ti y de ese negócio" (Ato I, 89). Foi um ato calculado de poder, que o levaria a se render a ela:

Llégate aça, putico, que no sabes nada del mundo ni de sus deleytes. ¡Mas rauia mala me mate, si te llego á mí, avnque vieja! Que la voz tienes ronca, las barbas te apuntan. Mal sosegadilla deues tener la punta de la barriga. (Ato I, 95)

A mesma gradação de insinuação "saber e poder"36 se repete no ato VII, quando Areúsa, com um resto de falso pudor, resiste a aceitar Pármeno na presença da madre. Para convencê-la de se relacionar com Pármeno, Celestina faz uso de concretas

${ }^{36}$ Termos utilizados por Arroyo (1984) 
indicações: "goce él de ti y tú de él” precedidas de elogios diretos: "¡Y qué gorda y fresca que estás!” e “iQué pechos y qué gentileza!”. E é assim, persuadido, que Pármeno dorme com Areúsa. Na manhã seguinte Celestina já o tem como seu aliado: “[...] ¿Con qué pagaré yo esto a la vieja Celestina? [...] Bien me decía la vieja que nada es bueno sin compañía” (Ato VIII). Pármeno repentinamente muda sua opinião com relação à Sempronio: “¡Oh, Sempronio, amigo y más que hermano!” (Ato VIII). Celestina consegue a adesão do seu auditório particular: Pármeno é seu aliado, enfim. Contudo, esse mais recente aliado é, na verdade, mais um competidor concorrente à recompensa paga por Calisto, mais um inimigo que Celestina terá por perto.

A conquista da adesão de Pármeno está diretamente relacionada à sua evolução na obra. Pármeno parte da condição de criado fiel ao amo ao apelo à sexualidade juvenil, mudança de valores que o leva à infidelidade e desperta sentimentos como a cobiça, a ira e a covardia. Com a variação do éthos do destinatário, Celestina, como eficaz enunciatária, soube reforçar o valor para o apelo sexual, a chave para conquistar a adesão do criado aos seus objetivos. A velha contribui para o seu processo de corrupção e perversão. Entretanto, uma vez alcançada a adesão deste interlocutor, Celestina ignora a alteração na hierarquia de valor de Pármeno, a fortuna passa para primeiro plano, influenciada por Sempronio, que sempre perseguiu o dinheiro. Contudo, a mudança de valores do interlocutor da luxúria para a fortuna encontra nos valores prioritários da sócia avarenta um confronto.

\section{Conclusão}

Neste capítulo sobre a construção de Celestina analisamos as principais estratégias discursivas e como o personagem domina as situações de controvérsia e plurivocidade. O personagem é construído através de vários recursos verbais — comparação, ironia, ambiguidade, paráfrase, correção, repetição, metáfora, reformulação, citação, vários tipos de argumentos e apropriação do discurso alheio - e recursos não verbais - silêncio, pausa, solilóquio, hesitação, microdiálogos — que exprimem seus pensamentos e paixões. $\mathrm{O}$ autor explora as influências extratextuais como as citações a Sêneca, ditos e refrães que apelam ao senso comum.

A significação do discurso histórico de Celestina é imanente à matéria enunciada, assim como diz Barthes: 
Os significados do discurso histórico podem ocupar pelos menos dois níveis. Há em primeiro lugar um nível imanente à matéria enunciada; este nível retém todos os sentidos que o históriador dá voluntariamente aos factos que relata; desta espécie podem ser as "lições", morais ou políticas, que o narrador tira de certos episódios. (1987:127)

Como se vê, pela sua própria estrutura do razoamento de Celestina e sem que seja necessário fazer apelo à substância do conteúdo, seu discurso histórico é essencialmente a elaboração ideológica ou, mais precisamente, imaginária, se é certo que "o imaginário é a linguagem por meio da qual o enunciador de um discurso (entidade puramente linguística) "enche” o sujeito da enunciação (entidade psicológica ou ideológica)". (BARTHES, 1987: 128). Esse discurso é elaborado, ideologicamente, por Rojas que transmite sua posição político-ideológica ao colocar os argumentos nas vozes dos personagens.

A trajetória da argumentação do personagem evidencia a estreita ligação entre razão e valores, logo também há um componente lógico para o exercício da persuasão. Olivier Reboul (2000) afirma que "razão e sentimentos são inseparáveis" que se soma ao que Rui Alexandre Grácio (1993) desenvolveu sobre a concepção de racionalidade argumentativa, aquela que conjuga componentes lógicos e afetivos; Grácio afirma que “[...] se a razão é razão humana, ela não pode ser esvaziada de conteúdo, desligada de toda a referência a valores e convicções" (1993:23). Complementando a ideia de relativização, Teresa Cecília de Oliveira Ramos (2002: 78) afirma que:

[...] o diálogo assume seu caráter prioritário dentro da obra por ser utilizado como arma de convencimento: mais do que utilizar seu discurso para explicar ou refletir, os personagens colocam o discurso a serviço do convencimento do outro para a obtenção de seus objetivos. Assim, tudo que é dito pode ser relativizado e assumir um caráter distinto que se adequa às condições do momento [...]

O uso da ironia traz em seu bojo a ambiguidade, pois "quer-se dar a entender o contrário do que se diz" (PERELMAN \& OLBRECHTS-TYTECA, 2002, p. 235). Na verdade, o efeito irônico não é do enunciado, mas sim do discurso: dá-se a partir da interpretação do alocutário (DUCROT, 1987, p. 78). A análise do discurso de Celestina nos leva à colocação feita por Gilman (1978:359) que diz que as "contraposições relativizam as afirmações”, o que, segundo Teresa Cecília de Oliveira Ramos (2002:82), pode ser agrupado em três níveis:

1. A contraposição entre o que dizem e como atuam,

2. A contraposição entre o que dizem para seus diferentes interlocutores dentro do texto, 
3. A contraposição entre o que dizem e como são interpretados.

A contraposição no discurso de Celestina leva à relativização do que é afirmado, à possibilidade de diferentes interpretações, à criação da ambiguidade e à ironia entre o plano ideológico e o plano concreto de suas ações.

A construção do discurso de Celestina como perspicaz enunciadora está associada ao sucesso da retórica das suas palavras. Para tanto, o éthos de enunciadora cumpriu eficazmente os preceitos das dimensões estética, ética e dialética. Na dimensão estética, a enunciadora soube expressar seus argumentos de maneira que impressionasse pela experiência e tocasse as paixões dos seus destinatários. Na dimensão ética, Celestina legitima com provas, como o cordão de Melibea, de que consegue persuadi-la, viabiliza os encontros amorosos dos nobres e dos criados e decide quando há controvérsia. $\mathrm{Na}$ dimensão dialética, compreende os valores dos seus interlocutores, sustenta a negociação através da concessão de favores, justifica seus objetivos de enriquecimento por ser velha, a mais experiente dos personagens, e refuta os argumentos contrários, por ainda não terem vivido o que ela já vivera. 


\section{A DESCONSTRUÇÃO DE CELESTINA}

¡O vieja avarienta, garganta muerta de sed por dinero! ¿No serás contenta con la tercia parte de lo ganado?

Sempronio (XII, Cena 10, p. 390). 


\section{Introdução}

Neste capítulo analisamos o segundo texto do corpus, no qual identificamos o auge do processo de desqualificação de Celestina no discurso. Esse processo começa quando a principal característica do seu discurso, a persuasão, deixa de ser tão eficaz como vinha sendo ao longo da obra. Contudo, a raiz da desconstrução do personagem no seu discurso começa concomitantemente com a construção deste porque, para persuadir seus destinatários, Celestina planta a semente da cobiça, da ganância e da luxúria em Sempronio e Pármeno. Assim, eles formularão discursos antagônicos ao seu para alcançar os mesmos objetivos que ela, o dinheiro que Calisto pagou pela mediação amorosa com Melibea.

Celestina não consegue mais a mesma adesão de Pármeno e Sempronio aos seus propósitos particulares de ganância como vinha conquistando a cada etapa. Os criados não conheciam a sua verdadeira e principal tese, a de ser a única beneficiária do negócio com Calisto; os criados esperavam da enunciadora, até aquele momento, a facilitação amorosa com as prostitutas como principal valor. Contudo, no momento em que Celestina recebe a corrente de ouro de Calisto como pagamento pelos seus serviços de terceira, os criados percebem o quanto ganaciosos são, motivados pela própria sócia. Portanto, exigem ganhar mais que os prazeres sexuais facilitados pela alcoviteira, querem também os lucros em dinheiro, que passam a ser seus valores prioritários.

Enquanto as ações de Celestina satisfazem seus destinatários - através das certeiras escolhas dos valores prioritários para eles — pode manter-se no poder controlando as atitudes dos criados. A ocultação da sua verdadeira proposição, a de desfazer a sociedade com seus aliados para ficar com todo o dinheiro, pode se sustentar através de argumentos persuasivos que atingiam as paixões que eram hierarquicamente mais valorizadas pelos destinatários nas atuais circunstâncias: as relações sexuais. Entretanto, uma vez saciada a principal paixão, os destinatários revelam a nova hierarquia de valores: o dinheiro. Diante das novas circunstâncias, a enunciadora se ve obrigada a revelar o que, até então, estava no campo da linguagem não verbal, a ocultação do seu verdadeiro éthos, a sócia avarenta. É na revelação dos seus propósitos que Celestina apresenta a sua verdadeira imagem, que é rechaçada pelos criados, seus destinatários e sócios no negócio. 
Consequentemente, sob a dimensão ética, a sua imagem de confiança e credibilidade - necessária a todo acordo - não se mantém porque a ilusão de ter eliminado o conflito ao negar a sua existência é falsa e leva ao fim do diálogo.

Celestina retarda o reconhecimento da controvérsia e não se arma argumentativamente para negociar as diferenças: a princípio, prega a reconciliação a todo preço através do diálogo e, como é avarenta por essência, não cogita a possibilidade de dividir os ganhos. Evitar afrontar a questão econômica diretamente como o faz a enunciadora não causa o efeito de sentido esperado porque as bases de negociação apresentadas por ela já não são as prioridades na hierarquia de valores dos seus destinatários. O ponto de base do conflito entre a enunciadora Celestina e seus destinatários está na esfera econômico-social, ligado ao deslocamento de valores dos criados e ao exercício de decisão monopolizado nas mãos da velha e experiente alcoviteira. Com a mudança de posição dos valores dinheiro e sexo na hierarquia dos destinatários, o discurso de Celestina deveria ter sido mais flexível para rever as bases da negociação e ter se adaptado às novas circunstâncias, evitando assim o embate.

Se, por um lado, a falta de tolerância dos criados em rever o acordo com a velha contribui para aumentar as hostilidades, por outro, não há vontade da parte de Celestina em minimizar as distâncias. Eles não abrem concessões e refutam a tese de que só ela deva ser a única beneficiada financeiramente. Nesse confronto, a argumentação não se sustenta como recurso para manter a comunhão dos espíritos e, portanto, não pode excluir o uso da violência. Os sentimentos partilhados entre os destinatários Pármeno e Sempronio - o ódio, que toca o domínio das paixões, e a ganância - são elementos de análise da Retórica que não poderiam sobrepassar à modalização do discurso.

Ao longo da trama, a trajetória do discurso de Celestina para persuadir, por um lado os ricos e nobres, Calisto e Melibea, e por outro os criados, Pármeno e Sempronio, toma rumos diferentes graças à mudança da imagem que os criados fazem dela. Esses, ao desconfiar dos valores morais de Celestina, exigem dela o cumprimento do acordo. Diante da falta de negociação, os criados rompem a aliança, o que os leva ao rompimento do diálogo com a agressão física. 


\section{O processo de desconstrução de Celestina no discurso - a intervenção do discurso do outro}

Celestina, com o apoio de Sempronio, ao conquistar a confiança de Calisto, unindo-o a Melibea, recebe a recompensa em joia e dinheiro, objeto do embate entre os sócios.

Antes, porém, a eficácia do discurso para persuadir Melibea - a grande conquista retórica de Celestina na obra porque foi precedida de momentos de angústia, medo e hesitação da enunciadora - , pode ter sido facilitado por três fatores:

1. Melibea já estaria apaixonada por Calisto desde o primeiro encontro no jardim.

2. O conjuro a Plutão, além de causar um efeito cenográfico verossímil para a época, pode representar, a partir da perspectiva do sincretismo religioso, uma máscara pagã diante da crítica contra a imposição religiosa daquele momento histórico.

3. Melibea se revolta com sua condição de donzela filha de pais ricos na sociedade de transição para a Idade Moderna em que estaria destinada a alguém que seu pai lhe escolhesse para juntar fortunas.

Contrariamente à mudança da imagem que os criados tinham de Celestina, o discurso para persuadir Melibea é bem-sucedido porque a sua imagem de mediadora se mantém a mesma após o par nobre e rico alcançar seus objetivos: o prazer sexual. Celestina e os criados são meros instrumentos para que eles alcançem seus desejos amorosos. A visão individualista e egocêntrica dos ricos, aliada ao descaso e à indiferença pelas classes sociais mais baixas, faz com que Calisto e Melibea ignorem a imagem e o trágico destino de Celestina e dos criados. Com a morte destes, Calisto, egocêntrico, se preocupa com a sua honra.

Pode-se afirmar que, até então, o discurso de Celestina com Sempronio e Pármeno vinha sendo bem-sucedido porque ela construíra na dimensão dialética uma imagem de confiança sob a promessa de riqueza e luxúria, despertando-lhes a cobiça. Contudo, a desconstrução da imagem da velha enunciadora começa com a desconfiança sobre o seu caráter, o seu éthos, por parte dos seus aliados, com quem ela havia feito um acordo prévio para repartir a recompensa. 
A concepção de éthos para a Análise do Discurso, engendrada por Maingueneau (2005) está relacionada a diversos elementos discursivos: tom, caráter e corporalidade, elementos constituintes da cenografia do discurso e também pelos estereótipos que circundam socialmente como categorias que influênciam na formação da imagem do enunciador. Dessa forma, a categoria do éthos de Celestina não está ligada apenas a ela como enunciadora, nem somente à imagem que ela reivindica para si própria, mas se apresenta como uma categoria interativa, uma vez que a imagem dos seus mais frequentes enunciadores - Sempronio, Pármeno, Calisto e Melibea — se adequam às expectativas de um auditório particular, que direcionam e dirigem o discurso dos primeiros.

A desconstrução da imagem de Celestina no seu discurso culmina com a ganância que impede que ela modalize com os seus aliados os pontos de negociação do acordo. A enunciadora sequer argumenta persuasivamente para reconhecer no ponto de vista dos seus interlocutores os valores que ela mesma tinha aguçado como a cobiça. A própria enunciadora constrói o éthos dos seus antagonistas ao despertar neles paixões como a cobiça e a luxúria.

No Ato XII há um rompimento na trajetória da linha condutora das ações na obra. A primeira parte da trajetória apresenta vários encontros cujo motor das ações o amor, o sexo, o carpe diem e a paixão vivida intensamente - é a causa do ritmo ascendente. Entretanto, neste ato vemos ações opostas às anteriores, temos as consequências da primeira ação da trajetória com o traçado de uma linha descendente conduzida por outro motor das ações - a morte de Celestina leva a uma sequência de outras mortes. Os assassinos da velha são mortos no Ato seguinte, as prostitutas planejam a morte de Calisto que acontece no Ato XIX, deixando os criados Sósia e Tristán sem amo e, como consequência, Melibea se suicida no Ato XX, deixando Pleberio arruinado e sua mãe, Alicia, semimorta.

$\mathrm{Na}$ Cena nove do Ato XII surgem os primeiros indícios que levariam à desqualificação de Celestina no discurso. Nesta cena, Sempronio e Pármeno não só anunciam a descrença no caráter de Celestina, como também revelam seu verdadeiro éthos: a cobiça pelo dinheiro de Calisto é mais valiosa que as relações amorosas com as prostitutas. Eles ameaçam assustá-la caso percebam alguma tentativa de enganá-los.

Com o objetivo de facilitar a análise, a exemplo do primeiro texto do corpus no capítulo anterior, dividimos em partes o segundo texto, o da desconstrução do razoamento da alcoviteira em função da intervenção do outro, cujo estilo se caracteriza 
por ser um diálogo de réplicas e tréplicas contundentes, realistas e costumbristas, de recursos expressivos que variam de coloquiais a agressivos.

A primeira parte da análise corresponde à cena que revela a predisposição dos criados para um confronto com Celestina, a que precede à falta de acordo: Sempronio e Pármeno, ainda em casa de Calisto, anunciam o que vem a ser o primeiro indício, dentro da dimensão ética, da perda de credibilidade no discurso da enunciadora:

Pármeno - ¿Adónde yremos, Sempronio? ¿A la cama a dormir o a la cozina a almorzar?

Sempronio - Ve tú donde quisieres, que antes que venga el día quiero yo yr a Celestina a cobrar mi parte de la cadena. Que es una puta vieja; no le quiero dar tiempo en que fabrique alguna ruyndad con que nos escluya.

Pármeno - Bien dizes; olvidado lo avia. Vamos entramos, y si en esso se pone, espantémosla de manera que le pese. Que sobre dinero no ay amistad.

A segunda parte corresponde à mudança de cenário para a casa de Celestina, lugar em que, se por um lado Celestina revela a indisposição para receber os criados sentimento agravado depois de ter ganhado a corrente de ouro de Calisto - , por outro, Sempronio demonstra ansiedade e nervosismo ao falar com ela. Trata-se de outro indício de que a comunicação não será fluente porque falta o assentimento entre os interlocutores, desvelado através do diálogo de réplicas e tréplicas curtas e contundentes.

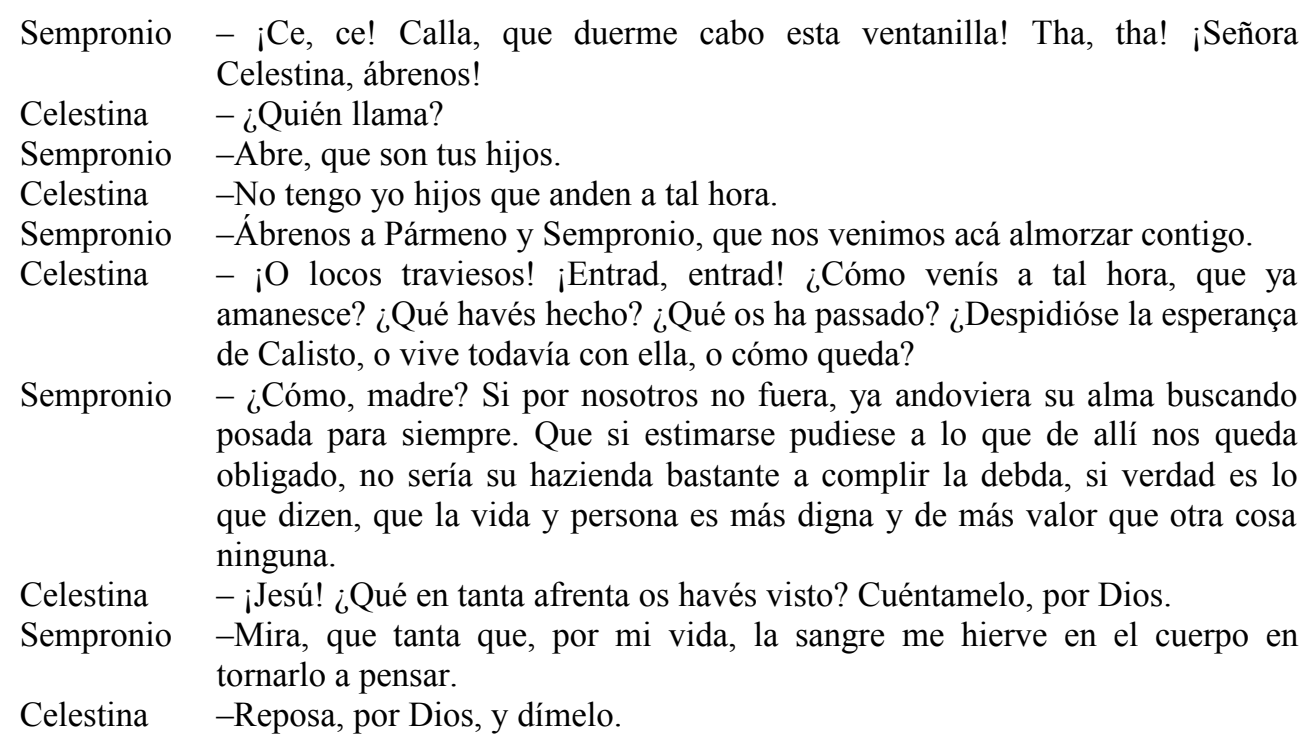

A terceira parte caracteriza-se por turnos de voz maiores para Sempronio e réplicas mais curtas de Celestina, o que representa uma mudança radical no histórico dos diálogos da obra em que Celestina esteve presente. Majoritariamente, ela sempre fora a principal enunciadora. Nesse momento da trama, o criado é o enunciador e 
Celestina, a interlocutora. A mudança dos papéis na enunciação representa diretamente a mudança de poder no discurso.

Embora Sempronio diga que o motivo da sua alteração é o das armas despedaçadas, o efeito de verdade é inverossímil porque, como ele não trabalha dentro do campo do razoável, a sua dissimulação não convence Celestina. As razões apresentadas pelo criado, as quais motivaram a sua alteração além de ocultar a intenção de resgatar a sua parte em dinheiro, não justificam por si só a quebra de confiança na sua interlocutora que, por sua vez, ignora os sentimentos do seu destinatário. A reação de Celestina é a de investir em que Calisto solucionará o problema das armas despedaçadas, paradoxalmente ao que sempre argumentara que Calisto é amo e não se sensibiliza pela causa dos criados:

[...] pídelo, fijo, a tu amo, pues en su servicio se gastó y quebró. Pues sabes que es persona que luego lo complirá; que no es de los que dizen: "vive comigo y busca quien te mantenga". Él es tan franco que te dará para esso y para más.

A velha não modaliza o seu razoamento diante das paixões dos seus destinatários e, ao contrário, procura os caminhos que não comprometam os seus propósitos de não dividir o dinheiro ganho com Calisto. Em contrapartida, Sempronio disputa os turnos de voz com Celestina, empregando os mesmos recursos expressivos ora utilizados por ela para a ocultação do seu propósito.

Sempronio - Cosa larga le pides según venimos alterados y cansados del enojo que havemos havido. Farías mejor en aparejarnos a él y a mí de almorzar; quiçá nos amansaría algo la alteración que traemos. Que cierto te digo que no querría ya topar hombre que paz quisiesse. Mi gloria sería agora hallar en quien vengar la yra que no pude en los que nos la causaron, por su mucho huyr.

Celestina - ¡Landre me mate, si no me espanto en verte tan fiero! Creo que burlas. Dímelo agora, Sempronio, tú, por mi vida. ¿Qué os ha passado?

Sempronio - Por Dios, sin seso vengo, desesperado, aunque, para contigo, por demás es no templar la yra y todo enojo y mostrar otro semblante que con los hombres. Jamás me mostré poder mucho con los que poco pueden. Traygo, señora, todas las armas despedaçadas: el broquel sin aro; la espada, como sierra; el caxquete abollado en la capilla. Que no tengo con qué salir un passo con mi amo, quando menester me aya; que quedó concertado de yr esta noche que viene a verse por el huerto. Pues, ¿comprarlo de nuevo? ¡No mando un maravedí en que caya muerto!

Celestina - Pídelo, fijo, a tu amo, pues en su servicio se gastó y quebró. Pues sabes que es persona que luego lo complirá; que no es de los que dizen: "vive comigo y busca quien te mantenga" Él es tan franco que te dará para esso y para más.

Sempronio $\quad-i \mathrm{Ha}_{\mathrm{i}}$ Trae también Pármeno perdidas las suyas; a este cuento, en armas se le yrá su hazienda. ¿Cómo quieres que le sea tan importuno en pedirle más de lo que él de su propio grado haze, pues es arto? No digan por mí que dándome un palmo pido quatro. Dionos las cient monedas, dionos después la cadena. A tres tales aguijones no terná cera en el oýdo; caro le costaría ese negócio. 
Contentémonos con lo razonable; no lo perdamos todo por querer más de la razón, que quien mucho abarca, poco suele apretar.

A quarta parte deste diálogo caracteriza-se pelo longo parlamento oratório sem margem para réplica por parte de Celestina, o que, sem interrupções, lhe propicia o emprego de ao menos seis argumentos diferentes para se desviar do confronto com Sempronio:

$1^{\circ}$ argumento: A velha, ao dizer que não tem relação com o problema entre Sempronio e Calisto, prega a separação com a divisão do dinheiro que é para ele e o que ela ganhou: "¿Qué tiene que hazer tu galardón con mi salario, tu soldada con mis mercedes? ¿Só yo obligada a soldar vuestras armas, a cumplir vuestras faltas?”

$2^{\mathbf{o}}$ argumento: Celestina diz que Sempronio se apegou a algo que ela disse antes, mas algo sem importância:

[...] si no te has asido a una palabrilla que te dixe el otro día viniendo por la calle: que quanto yo tenía era tuyo, y que en quanto pudiesse con mis pocas fuerças jamás te faltaría, y que, si Dios me diesse buena manderecha con tu amo, que tú no perderías nada. Pues ya sabes, Sempronio, que estos ofrescimientos, estas palabras de buen amor, no obligan.

$3^{\circ}$ argumento: Ela lança um argumento falacioso, o de ter sido furtada a corrente, cujo fato não poderá comprovar:

Di a esta loca de Elicia, como vine de tu casa, la cadenilla que traxe, para que se holgasse con ella, y no se puede acordar dónde la puso. Que en toda esa noche ella ni yo no avemos dormido sueño, de pesar. No por su valor de la cadena, que no era mucho, pero por su mal cobro della. Y de mi mala dicha entraron unos conocidos y familiares míos en aquella sazón aquí. Temo no la ayan levado diziendo: "si te vi, burléme" etc.

$4^{0}$ argumento: Celestina, ignorando que falaciosamente fora furtada a corrente de ouro, argumenta que é dela, como se a tivesse em mãos, porque o fez por merecer:

Assí que, hijos, agora que quiero hablar con entramos, si algo vuestro amo a mí me dio, devés mirar que es mío; que de tu jubón de brocado no te pedí yo parte, ni la quiero. Sirvamos todos, que a todos dará según viere que lo merescen; que si me ha dado algo, dos vezes he puesto por él mi vida al tablero. Más herramienta se me ha embotado en su servicio que a vosotros; más materiales he gastado, pues avés de pensar, hijos, que todo me cuesta dinero. 
$5^{0}$ argumento: A velha apela para a memória afetiva de Pármeno: "Y aun mi saber, que no lo he alcançado holgando, de lo qual fuera buen testigo su madre de Pármeno, ¡Dios aya su alma!”.

$6^{\circ}$ argumento: Celestina volta a alegar que foi ela quem trabalhou para ganhar a recompensa de Calisto, portanto eles não merecem aproveitar-se da sua fortuna, devem contentar-se com as prostitutas:

\begin{abstract}
Esto trabajé yo; a vosotros se os debe essotro. Esto tengo yo por oficio y trabajo; vosotros por recreación y deleyte. Pues assí, no havés vosotros de aver ygual galardón de holgar que yo de penar. Pero aun con todo lo que he dicho, no os despidáys, si mi cadena parece, de sendos pares de calças de grana, que es el ábito que mejor en los mancebos paresce. Y si no, recebid la voluntad, que yo me callaré con mi pérdida. Y todo esso de buen amor, porque holgastes que hoviese yo antes el provecho destos passos, que no otra. Y si no os contentardes, de vuestro daño farés.
\end{abstract}

Neste momento, Sempronio, a cada momento mais exaltado, divide igualmente os turnos de voz com Celestina, fato que revela um diálogo mais rápido e conciso nas réplicas e tréplicas. O criado, por sua vez, desvela o éthos de Celestina e, apoiado por Pármeno, revela, enfim, o verdadeiro propósito do diálogo: querem os dois terços do negócio que lhes correspondem. Celestina, em contrapartida, insiste em lhes oferecer mais prostitutas, provocando um efeito de sentido contrário ao desejado por ela:

Sempronio - No es esta la primera vez que yo he dicho quánto en los viejos reyna este vicio de cobdicia: quando pobre, franca; quando rica, avarienta. Assí que, adquiriendo cresce la cobdicia y la pobreza cobdiciando, y ninguna cosa haze pobre al avariento sino la riqueza. ¡O Dios, y cómo cresce la necessidad con la abundancia! ¡Quién la oyó a esta vieja dezir que me llevasse yo todo el provecho, si quisiesse, deste negócio, pensando que sería poco! Agora que lo vee crescido, no quiere dar nada, por complir el refrán de los niños, que dizen: "de lo poco, poco; de lo mucho, nada".

Pármeno - Dete lo que te prometió, o tomémoslo todo. Harto te dezía yo quién era esta vieja, si tú me creyeras.

Celestina - Si mucho enojo traes con vosotros o con vuestro amo, o armas, no lo quebréys en mí. Que bien sé dónde nasce esto; bien sé y barrunto de qué pie coxqueáys. No, cierto, de la necessidad que tenéys de lo que pedís, ni aun por la mucha cobdicia que lo tenéys, sino pensando que os he de tener toda vuestra vida atados y cativos con Elicia y Areúsa, sin quereros buscar otras, movéysme estas amenazas de dinero, ponéysme estos temores de la partición. Pues callá, que quien estas os supo acarrear, os dará otras diez, agora que ay más conoscimiento y más razón y más merecido de vuestra parte. Y si sé complir lo que prometo en este caso, dígalo Pármeno. ¡Dilo, dilo, no ayas empacho de contar cómo nos pasó quando a la otra dolía la madre!

Sempronio - Yo dígole que se vaya y abáxase las bragas; no ando por lo que piensas. No entremetas burlas a nuestra demanda, que con ese galgo no tomarás, si yo puedo, más liebres. Déxate comigo de razones. A perro viejo, no cuz, cuz. Danos las dos partes por cuenta de quanto de Calisto has recebido, no quieras 
que se descubra quién tú eres. ¡A los otros, a los otros con essos halagos, vieja!

Celestina não modaliza com as paixões dos sócios e se desvela segundo a imagem que faz de si mesma - "soy una vieja qual Dios me hizo, no peor que todas" —, ao que Pármeno reage mal ao ouvir a memória da sua mãe: "no me hinches las narizes con essas memorias". A velha faz uso do argumento de inferioridade por ser mulher: "como nos veys mujeres, habláis y pedís demasías".

Celestina.- ¿Quién só yo, Sempronio? ¿Quitásteme de la putería? Calla tu lengua, no amengues mis canas, que soy una vieja qual Dios me hizo, no peor que todas. Vivo de mi oficio como cada qual oficial del suyo, muy limpiamente. A quien no me quiere, no le busco. De mi casa me vienen a sacar. En mi casa me ruegan. Si bien o mal vivo, Dios es el testigo de mi coraçón. Y no pienses con tu yra maltratarme, que justicia ay para todos, a todos es ygual; tan bien seré oýda, aunque mujer, como vosotros muy peynados. Déxame en mi casa con mi fortuna. Y tú, Pármeno, ¿piensas que soy tu cativa, por saber mis secretos y mi passada vida y los casos que nos acaescieron a mí y a la desdichada de tu madre? ¡Y aun así me tratava ella, quando Dios quería!

Pármeno.- No me hinches las narizes con essas memorias; si no, embiarte he con nuevas a ella, donde mejor te puedas quexar.

Celestina.-¡Elicia, Elicia! ¡Levántate dessa cama, da acá mi manto presto, que, por los sanctos de Dios, para aquella justicia me vaya, bramando como una loca! ¿Qué es esto? ¿Qué quieren decir tales amenazas en mi casa? ¿Con una oveja mansa tenés vosotros manos y braveza? ¿Con una gallina atada? ¿Con una vieja de sesenta años? ¡Allá, allá con los hombres como vosotros! Contra los que ciñen espada mostrá vuestras yras, no contra mi flaca rueca. Señal es de gran covardía acometer a los menores y a los que poco pueden. Las sucias moxcas nunca pican sino los bueyes magros y flacos; los guzques ladradores a los pobres peregrinos aquexan con mayor ímpetu. Si aquella que allí está en aquella cama me oviesse a mí creýdo, jamás quedaría esta casa de noche sin varón, ni dormiríemos a lumbre de pajas, pero por aguardarte, por serte fiel, padescemos esta soledad. Y, como nos veys mujeres, habláis y pedís demasías. Lo qual, si hombre sintiéssedes en la posada, no haríades; que, como dizen: "el duro adversario entibia las yras y sañas".

Acabam-se os longos parlamentos com os argumentos de defesa e ataque por parte dos interlocutores porque se aproxima a falta de diálogo por não ter mais o que negociar: é a falta de acordo e o aumento intransponível das distâncias. Começam os insultos à face do outro:

Sempronio $\quad-~ ¡ O$ vieja avarienta, garganta muerta de sed por dinero! ¿No serás contenta con la tercia parte de lo ganado?

Celestina $-¿$ Qué tercia parte? ¡Vete con Dios de mi casa, tú! Y essotro no dé vozes, no allegue la vezindad. No me hagáys salir de seso. No queráys que salgan a plaza las cosas de Calisto y vuestras.

Sempronio - Da vozes o gritos, que tú complirás lo que tú prometiste, o se complirán oy tus días.

Elicia $\quad-$ ¡Mete, por Dios, el espada! Tenle, Pármeno, tenle; no la mate esse desvariado. 


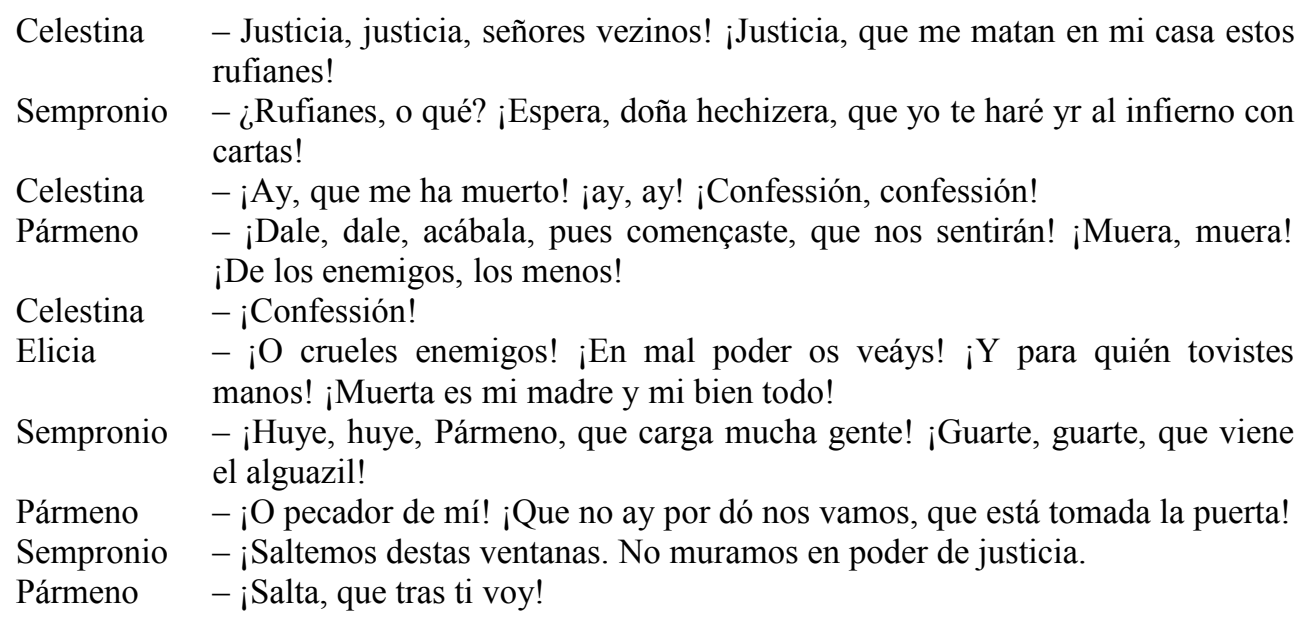

\section{1. . Os indícios da falta de acordo entre os}

\section{interlocutores}

Os indícios da falta de acordo entre Celestina e os criados que ocorrem na Cena 10 já tinham sido revelados na cena anterior, em um curto espaço de tempo na casa de Calisto. Esses indícios são rapidamente desvelados em um diálogo de três falas concisas que revelam a opinião contundente dos interlocutores Sempronio e Pármeno sobre o negócio com Celestina. No ato XII temos a preparação da cenografia para o trágico diálogo que acontecerá na cena seguinte: uma conversa entre os criados na qual desvelam seus microdiálogos como uma consciência desintegrada, a que revela seu éthos efetivo. Também nesse diálogo, ainda na casa do amo porque não teria sentido se acontecesse na presença de Celestina, os criados revelam uma mudança na sua hierarquia de valores e intenções: se uniram à velha pela cobiça e ganância despertadas por ela mesma e, em segundo plano, pelas relações amorosas com as prostitutas. Uma vez que as circunstâncias mudam, há uma necessidade de ser revisto o acordo porque os criados, como destinatários de Celestina, ainda não conheciam a sua tese principal, propositalmente encoberta por ela através do recurso de veridicção.

Sempronio e Pármeno, ao aceitar a manipulação de Celestina, assinam um contrato de veridicção que, na Semiótica se refere ao dizer verdadeiro e não à verdade. $\mathrm{O}$ crer-verdadeiro deverá se instalar entre o enunciador e o destinatário, gerando aquilo a que chamamos de contrato de veridicção. Eles acreditam nas marcas veridictórias que apresentam a imagem de credibilidade de Celestina como sócia porque ela já apresentava um éthos positivo como o de uma velha experiente, com vários ofícios. Por 
estas razões, embora não tenham provas de que a sócia honraria a sua parte do contrato, os destinatários acreditam no seu efeito de sentido-verdade. Nessa situação, não se tem a adequação da linguagem ao referente na veridicção, o que se tem são marcas veridictórias implícitas no contrato. Conhecendo o éthos de Celestina como enunciadora, é possível acreditar em efeito de sentido verdade porque esse conceito se aproxima do de eficácia, do fazer persuasivo, cujo objetivo é conseguir a adesão do destinatário, decorrente do fazer interpretativo que este exerce. Portanto, ela consegue a adesão ao contrato porque foi eficaz no fazer persuasivo, consequência do "fazer interpretativo" por parte dos seus destinatários. A parte implícita do contrato são as zonas indeterminadas de interpretação ou zonas de ambiguidades que criam espaços a ser preenchidos pela mente dos destinários e leitores. O discurso de Celestina se desqualifica como eficaz à medida que, por um lado, falha o fazer persuasivo da enunciadora e, por outro, o fazer interpretativo dos destinatários não acredita no efeito de sentido-verdade do razoamento da velha.

Celestina não revela o seu objetivo principal desde o início porque, astuta como é, sabe que não conseguiria convencê-los a pensar que ela deveria ser a única beneficiária do negócio. Assim, uma vez que sabe que é pouco provável e nada razoável que pensem como ela, coloca todo o seu poder persuasivo em fazer com que ajam como ela quer para ser bem-sucedida no seu intuito. Com a mudança na hierarquia de valores dos destinatários e exatamente porque Sempronio e Pármeno não estão mais convencidos de que Celestina dividirá o dinheiro, que não os reconhecerá como seus sócios no negócio, resolvem ir para o confronto para cobrá-la. Celestina não os vê como sócios e sim como ferramentas para alcançar seus objetivos. Quando os criados desconfiam do não cumprimento do acordo demonstram que perderam a confiança na sua enunciadora e partem para o confronto pondo fim ao diálogo e à negociação.

Os criados como destinatários negociam com a sua eficaz enunciadora um novo sentido de veridicção, em busca de novas concessões para alcançar avanços de eliminar ou diminuir as distâncias entre eles. Entretanto, Celestina recua na negociação não abrindo novas concessões e aumentando as distâncias. O discurso dos três interlocutores é um exemplo de como a retórica é uma modalidade da argumentação e se nutre da consciência da distância entre eles, com movimentos que vão de sua valorização à desvalorização ou desqualificação, tendo por base o éthos, a identidade e o caráter de cada um deles como interlocutores. Todos exibem a cobiça e a ganância como suas principais paixões naquela negociação. 
Pragmaticamente, temos três curtos parlamentos que conduzem aos primeiros indícios da tragédia entre os criados e Celestina:

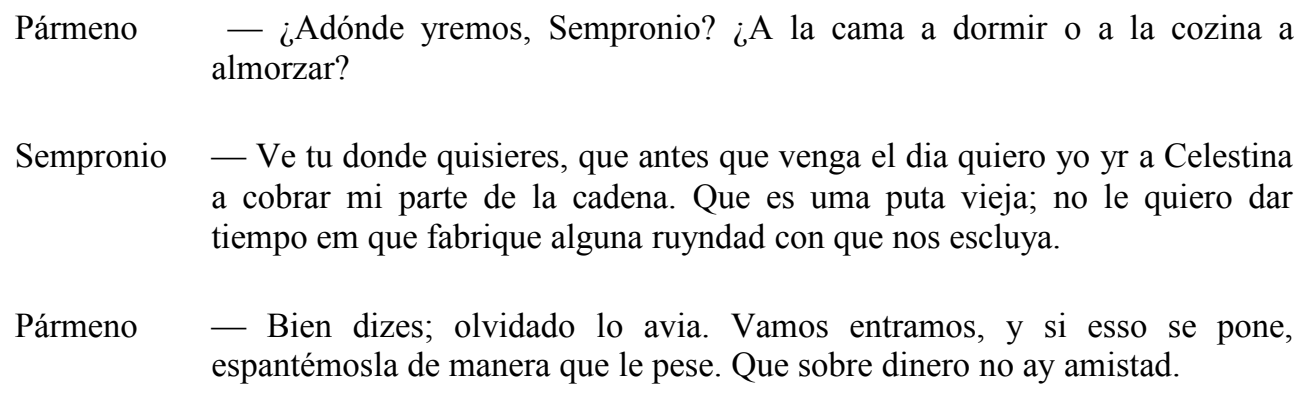

$\mathrm{Na}$ conversa entre os criados, apenas Pármeno revela um efeito de sentido de não premeditação dos atos trágicos da cena seguinte: “—_Adónde yremos, Sempronio? ¿A la cama a dormir o a la cozina a almorzar?”. Além do emprego de várias figuras sintáticas seguidas como recurso expressivo para reforçar a involuntariedade de qualquer atitude violenta - do zeugma, com a omissão do verbo ir, da anáfora, com a repetição da preposição "a", do pleonasmo com o reforço na relação entre cama e dormir e cozinha e almoçar - , o personagem destaca ainda seu caráter de passividade e conformidade com as ações de facilitadora amorosa de Celestina. Entretando, com alteridade muda facilmente para o tom e corporalidade agressivos do outro criado. Parte de Sempronio a atitude de aguçar a ganância do comparça naquela hora.

Opostamente a Pármeno, Sempronio já anuncia que será o principal enunciador da próxima cena ao responder a sua passiva pergunta de forma imponente: "-Ve tú donde quisieres, que antes que venga el día quiero yo yr a Celestina a cobrar mi parte de la cadena." O tom imperativo em "Ve tú donde quisieres" conota sua inconformidade com a passividade do seu parceiro e sua decisão ao reforçar que ele sim, vai reagir: “quiero yo yr a Celestina". Usa-se de personificação do "dia" para demonstrar seu imediatismo: "antes que venga el dia,". Sempronio tem pressa de receber a sua parte do negócio em dinheiro, por isso não vai esperar o amanhecer do dia seguinte para falar com Celestina. Ele já se sente traído pela parceira, que passa a ser o assunto, pois teme que ela não cumpra o trato. Ao fazer a antítese entre ir e vir: "antes que venga el día quiero yo ir a Celestina" pretende demonstrar ao parceiro que tomará uma atitude e isso se deve a que já não demonstra a mesma credibilidade pela velha: "que es una puta 
vieja", recurso expressivo garantido pela antonomásia, uma vez que era assim que Celestina era conhecida por todos.

Nesta cenografia temos subliminarmente apresentadas as consequências da falta de convencimento de Sempronio pelo objetivo principal de Celestina. Os criados não confiam na velha - o éthos da enunciadora não transmite mais credibilidade - , porém, por causa do apelo sexual ocorrido na negociação, até então estavam persuadidos a agir como ela queria. Quando Sempronio afirma que "no le quiero dar tiempo en que fabrique alguna ruyndad con que nos escluya" revela seus verdadeiros sentimentos pela enunciadora: Celestina não aparenta mais ser confiável e também não consegue mais transmitir o efeito de verdade da sua proposição através dos seus argumentos. A metonímia "en que fabrique alguna ruyndad" expressa o que Sempronio pode esperar dela: uma fábrica de trapaças. Com esse argumento Sempronio facilmente persuade Pármeno a voltar-se contra a sócia, ao que ele responde: “-Bien dizes; olvidado lo avia. Vamos entramos [...]".

Pármeno se alia a Sempronio contra Celestina que, nesse momento, passa a ser o assunto e Sempronio, o principal enunciador. Quando Pármeno reitera dizendo "si en esso se pone, espantémosla de manera que le pese. Que sobre dinero no ay amistad" revela que, se antes a sua adesão aos propósitos de Celestina fora por causa de Areúsa, seus valores mudaram quanto ao objetivo principal. Portanto, o valor mais concreto, o dinheiro, a partir de então passa a ser mais importante que o sexo para Pármeno. O criado revela, assim, a característica essencial da sua personalidade, a alteridade: ele se adapta às situações que se apresentam mesmo que para isso tenha que corromper-se. Cabe-nos recordar que, a exemplo de Celestina, os criados na posição de enunciadores, empregam os mesmos recursos persuasivos que ela, como por exemplo, os refrães. Pármeno emprega o dito de Ovidio "sobre dinero no ay amistad" como recurso expressivo que lhe confere autoridade e aceitação diante de um argumento incontestável diante do senso comum.

Na cena seguinte Sempronio passa a principal enunciador revelando, portanto, uma importante mudança de posição na obra dos agentes sociais e dos enunciados porque outrora Celestina raramente fora enunciatária, o que demonstra que, para privilegiá-lo, os turnos de voz são maiores para ele. São diálogos de frases curtas caracterizados por réplicas contundentes. $\mathrm{O}$ tom é agressivo, que ofende a face do outro. É uma cena em que o leitor deve imaginar os tons de voz de Sempronio e de Pármeno 
mais ásperos e alterados compondo a corporalidade dos criados que passam à condição de enunciadores.

\subsection{A falta de acordo - o último diálogo de Celestina}

J. G. Maestro (2001) afirma que "Celestina jamás hubiera supuesto que habría de morir apuñalada por sus propios mochachos". Exatamente ela própria, a que convencera Pármeno a ser seu aliado e despertara nele a cobiça e a ganância, criava o éthos dos seus antagonistas. Desde o início da empreitada, Sempronio se considerava um sócio, apesar de ela jamais tê-lo incluído na divisão do ganho. O personagem mais velho e experiente parece não ter consciência de que as possíveis consequências trágicas dos seus atos as pudessem levar à morte. Habilmente e astuciosamente Celestina vinha agindo com todos os personagens, mas não o suficiente para prever e impedir a sua própria morte porque a ganância lhe escureceu as possiblidades de modalização dos seus interlocutores.

É na instância do "outro" que há a possibilidade do convencimento, assim como é mister reconhecer como é honroso ser convencido e aceitar suas limitações ao convencer. A arrogância é fruto da subestimação do “outro". Rojas quis puni-la por seus atos maquiavélicos em uma atitude moralmente paródica? Essa pergunta não é unicamente uma dúvida, mas uma busca de sentido, assim como a morte não é uma punição, mas um repensar, um reconhecimento dos elementos que a constituem: entre outros, a ganância.

A ganância de Celestina não permite persuadir os criados rapinas, frutos de sua própria cria, cuja concepção materialista apresenta muitos pontos em comum com o gênero picaresco. Maravall (1986) compara os dois mundos pela ganância:

El afán de dinero se muestra en unos [los personajes celestinescos] y otros [los pícaros], no como en la comedia barroca que procuraba exculpar a los señores; en indivíduos de estratos altos y bajos se señala el vicio o pecado de la codicia, sólo que se observa una tendencia a insinuar, por lo menos, como más brutal y agresiva en sus consecuencias, la codicia que se manifiesta en los señores, a lo cual responde la negativa valoración de su conducta por los de abajo y su hostil actitud consiguiente. (1986:121)

Francisco José Herrera (1997) no seu artigo sobre a ganância na matéria celestinesca destaca geometricamente que a energia perseguida pelos protagonistas se hierarquiza em três objetivos, conformando um triângulo escaleno cujo lado maior era, 
ao menos a princípio, a fúria da relação amorosa principalmente entre os personagens nobres da obra. O segundo maior lado desse triângulo de objetivos é protagonizado pelo universo dos sentimentos dos criados e da alcoviteira; o lado menor representa a honra familiar e social, especialmente representada por Pleberio. Entretanto, os lados da figura geométrica sofrem alteração ao longo da trama: o interesse pessoal e a avareza dos criados e da velha alcoviteira ganham maior destaque passando a ser o lado maior do triângulo. A mudança da hierarquia de valores nos objetivos dos protagonistas representa a valorização da ganância pela riqueza material, da avareza e da cobiça sobre o amor e a honra. Celestina despertara tais sentimentos nos criados com o objetivo de te-los a seu lado, contudo, eles se sentiram iguais a ela, competidores pelo prêmio de Calisto.

O egoísmo é marcante nos diálogos que antecedem a morte de Celestina. Ela confia tanto em si mesma que não percebe o que está prestes a acontecer, o seu assassinato, por isso sequer modaliza os valores dos criados. $\mathrm{O}$ seu individualismo racionalista se encaixa nas características do pensamento renascentista, se se pode justificar uma paixão pelo contexto histórico em que fora pronunciada.

A faca de Celestina é a sua linguagem retórica: a sua língua felina. Ela reverte a imagem logocêntrica da cicatriz em uma facada contra si mesma. Quando morre esfaqueada por Sempronio, Elicia conta a Areúsa que "mill cuchilladas le vi dar a mis ojos; en mi regazo me la mataron"(XV, Cena 3, p.522) é a consequência da metáfora língua afiada - traição - assassinato pelos aliados.

Segundo J. G. Maestro ${ }^{37}$, Celestina, como os demais personagens de Rojas, só é consciente do primeiro de seus impulsos e desfruta o momento como que embriagada pela ingênua perversão e, quando descobre as consequências reais do que a sua imoralidade provoca, já é muito tarde para evitar a fatalidade. Rojas não evita a morte, pois ela espelha a sua desesperança nos valores renascentistas que se apresentam na obra; os personagens que valorizaram a cobiça, a ganância ou a avareza, o carpe diem e

${ }^{37}$ In Tragedia, comedia y canon desde la teoría literaria moderna. El personaje nihilista de La Celestina -Jesús G. Maestro - Universidad de Vigo - A Tadeusz Kowzan http://www.cervantesvirtual.com/obra/tragedia-comedia-y-canon-desde-la-teoraliteraria-moderna-el-personaje-nihilista-en-la-celestina-0/ (artigo eletrônico consultado em março de 2009). 
o amor vivido intensamente espelham a visão que o autor tem da sociedade em que vive.

Pármeno e Sempronio já vinham degenerando progressivamente e, no último encontro com Celestina não controlam seus impulsos que acabam por convertê-los em vulgares assassinos, cujo final será uma vergonhosa execução pública.

O tratamento da morte, por outro lado, nutre-se da observação e se dá de maneira congenial. Com a possibilidade de terminar a obra de forma moralmente elegante com a morte dos personagens e trabalhando com a cronologia linear, Rojas escreve partindo do que é conhecido - da trajetória de vida do personagem imoral em direção à obscuridade. A morte anunciada de Celestina é imposta como atributo inexorável diante da incapacidade humana de explicar e justificar as coincidências irônicas da vida: o castigo excessivo para a que já tinha anunciada a morte na cicatriz do rosto. A linha descendente na obra se inicia após o assassinato do personagem mais velho que, então, se converte no motor das ações subsequentes: a execução pública dos criados assassinos e a trama das prostitutas e dos rufianes para conduzir os ricos à morte.

Considerando La Celestina um drama dialogado, o desempenho de personagens maquiavélicos como Celestina deixam marcas nos romances em geral, mesmo quando são sobre "pessoas perversas, podem nos consolar; sugerem uma raça humana mais compreensível e, consequentemente, mais dócil, nos dão a ilusão de perspicácia e poder" (FORSTER, 1998, p. 61).

Perelman e Olbrechts-Tyteca (1996) nos advertem que da mesma maneira que "ao auditório cabe o papel principal de determinar a qualidade da argumentação e o comportamento dos oradores", assim também "o importante na argumentação não é saber o que o próprio orador considera verdadeiro, ou probatório, mas qual é o parecer daqueles a quem ela se dirige”. O discurso final de Celestina não respeita a regra, isto é, não se adapta ao seu auditório, como confirmam os autores: "há apenas uma regra para o orador, que é a adaptação do discurso ao auditório" (PERELMAN, OLBRECHTSTYTECA, 1996, p. 72).

De acordo com Perelman (1988:137), a noção de acordo torna-se necessária, contudo, nos casos em que "faltam ou são insuficientes os meios de prova e, sobretudo, quando o objeto do debate não é a verdade de uma proposição, mas sim o valor de uma decisão, de uma opção ou de uma ação, consideradas como justas, equitativas, razoáveis, honrosas ou conforme o direito". A verdade ou falsidade de uma proposição é 
apenas um dos motivos de aceitação ou rejeição entre tantos outros: "uma tese pode ser admitida ou afastada porque é ou não oportuna, socialmente útil, justa ou equilibrada" (op.cit. 236).

A característica mais marcante nesta cena é a falta de fluidez do diálogo causada intencionalmente por Sempronio, principal destinatário neste momento do enredo, que prefere jogar com o efeito de sentido de ocultação e desvelo do pathos na expectativa de que sua enunciatária, Celestina, negocie as distâncias entre eles para evitar as trágicas consequências da falta de acordo.

À luz da dimensão estética deste diálogo entre Celestina e seus comparsas verificamos como os recursos expressivos e as estratégias da enunciadora despertam as paixões e alteram o juízo de valores nos criados. Na Retórica, as paixões são consideradas como reação à outra pessoa e, mais precisamente, resposta à representação que o enunciador faz em nosso espírito. As paixões refletem, em outras palavras, as representações que fazemos dos outros, considerando o que eles são para nós. Essas representações podem ser de amor, ódio, indignação, vergonha, admiração e outros sentimentos que, segundo Parret (1997) toda paixão tem suas razões como todo pathos tem seu logos. Esse autor postula a existência do "pathos razoável" no qual podemos explicar os sentimentos que determinaram a falta de acordo entre nossos interlocutores.

Severin (1977:697) afirma que a velha Celestina se coloca na posição de um mártir ao mesmo tempo em que despreza os sentimentos dos seus interlocutores para prevalecer os próprios:

Ya hemos notado otra combinación incongrua de comedia y tragedia cuando Celestina emplea imágenes heroicoburlescas en el momento de la muerte, Además, podemos notar que la manera de muerte de Celestina es también heroico-burlesca; la asesinan como si fuera un César.

Esta cena começa com onomatopeia: “—_Ce, ce! Calla, que duerme cabo esta ventanilla! Tha, tha! ¡Señora Celestina, ábrenos!” porque, sendo a obra escrita para ser lida por um único orador diante de um pequeno público, a presença de figuras de som cumprem sua função mnemônica e rítmica na produção de efeitos especiais de sentido, dentro da cenografia argumentativa.

Apesar de Sempronio, desde a cena anterior, já haver deixado claro que não confia em Celestina, ele ainda pretende causar um efeito de sentido verossímil ao tratála de forma carinhosa e respondendo à velha como já vinha sendo tratado, como um 
filho, fazendo uso do recurso expressivo através da antonomásia: "Abre, que son tus hijos". Se, por um lado, Sempronio tem de se apresentar diante da retórica possibilidade de que a velha não reconheça a sua voz, por outro lado, tem a expectativa de que ela, ao reconhecê-lo, o receba com disposição para cumprir o acordo.

Contudo, ela responde paradoxalmente "no tengo yo hijos que anden a tal hora", o que evidentemente não corresponde às expectativas do criado, uma vez que certa de saber quem bate à sua porta, ela prefere reclamar e negar o efeito causado pela antonomásia "hijos" em vez de recebê-los com o mesmo carinho. Quando Celestina diz "tal hora" emprega a figura da hipérbole para desviar-se do motivo da vinda dos sócios a sua casa. Este preâmbulo revela que a pouca animosidade por parte de Celestina em recebê-los causa o efeito de sentido verdade: o motivo da visita dos criados lhe era desconhecido. O tom irônico na fala da velha também contribui para mais um efeito de sentido retórico, que ela sequer suspeita da catastrófica realidade que a espera; a ironia do destino adota elementos da tragédia — a degradação dos protagonistas — e da comédia - a caricatura dos criados infiéis e da alcoviteira ingênua por não pressentir que a sua própria vida era desafiada.

Nas tres primeiras falas de Sempronio nesta cena a anáfora "ábrenos / abre / ábrenos" dá a cenografia uma corporalidade de personagem ansioso por parte de Sempronio temendo não ser recebido:

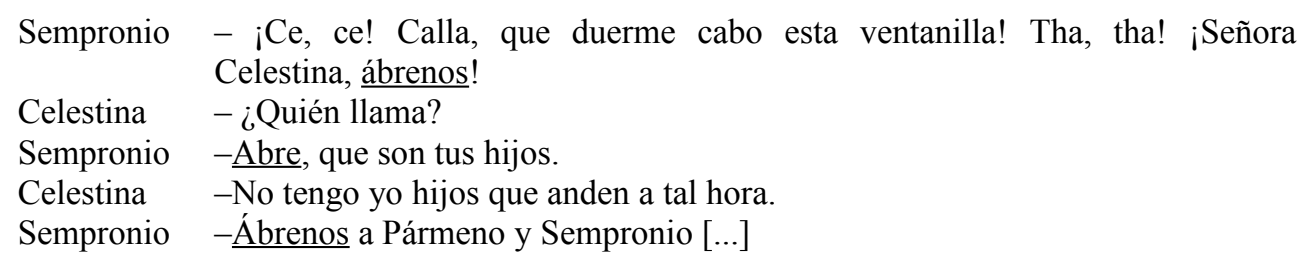

A ansiedade de Sempronio encontra motivação na resposta em que Celestina emprega outra anáfora, "a tal hora", para rebater a do criado:

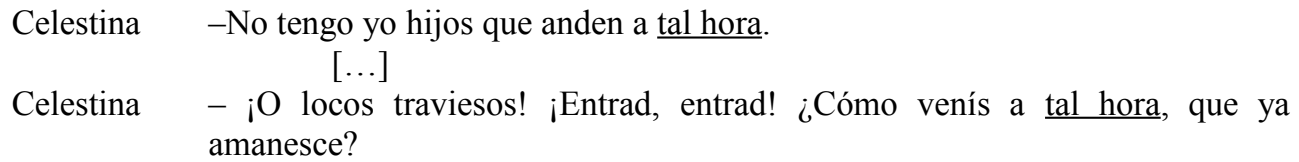

Celestina causa efeito de surpresa ao identificá-los e os trata como o de costume: “_ ¡O locos traviesos! ¡Entrad, entrad! ¿Cómo venís a tal hora, que ya amanesce?”. O vocativo "locos traviesos" dá a impressão de que a velha os trata como se parecessem 
mais jovens do que realmente são por causa do inconveniente de chegar tão cedo à sua casa, além de aumentar a distância entre a idade e experiência da enunciadora e a de seus interlocutores. Com isso, ao se distanciar dos sócios, Celestina demonstra que não está disposta a fazer nenhum acordo.

Ela novamente causa efeito de sentido-verdade quando finge não saber o motivo da visita dos sócios, pois pergunta sobre Calisto para desviar-se da verdade: “¿Despidióse la esperança de Calisto, o vive todavía con ella, o cómo queda?”. Trata-se do recurso expressivo red herring, uma falácia cometida para desviar a atenção e chegar a uma conclusão diferente com a introdução de material irrelevante ao assunto discutido. Entretanto, esse argumento surtiu efeito contrário, ao que Sempronio se irrita e responde com certa aspereza:

Si por nosotros no fuera, ya andoviera su alma buscando posada para siempre. Que si estimarse pudiese a lo que de allí nos queda obligado, no sería su hazienda bastante a complir la debda, si verdad es lo que dizen, que la vida y persona es más digna y de más valor que otra cosa ninguna.

Nessa resposta ácida Sempronio emprega a doxa "si verdad es lo que dizen" para falar de dignidade; além de saber que Calisto não tem como pagar-lhe a vida, se irrita com a intenção de Celestina de desviar para o amo o motivo da sua raiva. Ela, apesar de empregar a personificação de "esperança" — "despidióse la esperança de Calisto, o vive todavía con ella" - como recurso expressivo para mudar o foco da conversa para Calisto, dá os primeiros sinais de que não poderá mais fingir que não sabe qual é o verdadeiro motivo da exaltação do criado. Celestina não consegue mais sustentar o mesmo efeito de sentido-verdade, por isso pergunta aos criados: “¡Jesú! ¿Qué en tanta afrenta os havés visto? Cuéntamelo, por Dios".

Já temos um confronto promovido pelo movimento de avanço da agressividade do interlocutor e de recuo estratégico da enunciadora. Ela quer evitar o embate ao tentar diminuir o tom exagerado de Sempronio, ironizando-o pela intensidade quando diz "tanta afrenta". Celestina usa também palavras como "Jesú" e "Dios" para amenizar o tom da conversa apelando à religiosidade que ela finge ter, mas que espera que eles a tenham. Entretanto sua tentativa de diminuir a agressividade do diálogo se frustra quando Sempronio repete a palavra "tanta" empregada por ela com o tom de ironia e desdém: "Mira, que tanta que, por mi vida,[...]". 
Além do desdém, usa a metonímia como um recurso retórico para expressar seu estado de nervos: "la sangre me hierve en el cuerpo en tornarlo a pensar". Ao que a velha novamente tenta acalmá-lo voltando a apelar à religiosidade, contudo sem sucesso: "Reposa, por Dios, y dímelo". As várias tentativas de Celestina para evitar o confronto surtiram o efeito contrário: além de ser em vão, provocam o aumento da ira dos interlocutores e a distância entre eles. As repetições - "a tal hora", "tanta afrenta", "¿qué os havés passado", "dímelo"-, ao contrário do que pretende Celestina, amplificam a realidade e não desviam a atenção do real motivo da confrontação.

Celestina pede reiteradamente que Sempronio expresse o verdadeiro motivo do seu nervosismo na expectativa de que ele seja o primeiro a dizer diretamente a razão do confronto e o criado, por sua vez, espera que ela o faça antes dele, evitando um confronto maior. Trata-se fundamentalmente da subjetividade causada pelo jogo de ocultação e revelação constante no diálogo entre Sempronio e Celestina. O personagem joga com ocultar a causa e desvelar as consequências para produzir o efeito de sentido de movimento (kinésia) que leva às várias leituras a fim de preencher o espaço vazio deixado pelo seu interlocutor. A leitura de Celestina é a que lhe convém para evitar o confronto de idéias; habilmente ela transfere para Calisto a responsabilidade de ser o causador da ira de Sempronio empregando argumentos falaciosos.

Ela pede várias vezes — “QQué havés hecho? ¿Qué os ha passado? ¿Qué en tanta afrenta os havés visto? Cuéntamelo, por Dios [...] Reposa, por Dios, y dímelo. [...] Dímelo agora, Sempronio, tú, por mi vida ¿Qué os ha passado?” - para que ele revele o verdadeiro motivo da sua alteração, mas o criado, depois de muita insistência, faz uso de efeitos de sentido para se deviar da verdade, como a necessidade de novas roupas “"traygo, señora, todas las armas despedaçadas: el broquel sin aro; la espada, como sierra; el caxquete abollado em la capilla”. A quebra de confiança e credibilidade da sócia o leva a exigir a sua parte do negócio em dinheiro - "si es verdad lo que dizen, que la vida y persona es más digna y de más valor que otra cosa ninguna". Essa estratégia retórica de ocultar o verdadeiro motivo do embate cria um efeito de sentido ilusório, de fingimento, de tensão, de ocultação, o que não é favorável à adesão dos espíritos — "mi gloria sería agora hallar en quien vengar la yra que no pude en los que nos la causaron, por su mucho huyr." 
Essa cenografia de falso enigma do pathos entre os interlocutores causa à cena um tom pesado, ríspido e austero desvelado por Sempronio quando este emprega dois adjetivos seguidos para amplificar a dimensão da sua ira: “alterados y cansados del enojo" e, logo a seguir, o substantivo "quiçá nos amansaria algo la alteración que traemos". Essa aliteração de "alterados" e "alteración” é, além da anáfora, uma figura fonética para ampliar o efeito de sentido de reforçar a atenção de Celestina para o que ela está tentando menosprezar:

Cosa larga le pides según venimos alterados y cansados del enojo que havemos havido. Farías mejor en aparejarnos a él y a mí de almorzar; quiçá nos amansaría algo la alteración que traemos. Que cierto te digo que no querría ya topar hombre que paz quisiesse. Mi gloria sería agora hallar en quien vengar la yra que no pude en los que nos la causaron, por su mucho huyr.

O efeito de ambiguidade causado pelas orações condicionais - "farías mejor en [...] quiçá nos amansaría [...] te digo que no querría [...] mi gloria sería" — faz com que Sempronio não só mantenha oculto o pathos como também preveja os fatos futuros que acontecerão em relação à falta de acordo no presente. A conjugação dos verbos no futuro do pretérito conformando a oração condicional nos dá a entender que Sempronio, diante da tensividade das trocas comunicativas, cria o efeito de preterição para evitar o confronto com Celestina: "que cierto te digo que no querría ya topar hombre que paz quisiesse. Mi gloria sería agora hallar en quien vengar la yra que no pude en los que nos la causaron, por su mucho huyr". Recorre à elipse de sujeito, "en los que nos la causaron", uma vez que é sabido que se refere a Celestina, em mais uma tentativa de que ela reconheça o conflito - "por su mucho huyr" - e sugira um acordo. Para anunciar indiretamente o embate Sempronio mantém o paradoxo jogando com as palavras "paz" e "ira": "hombre que paz quisiesse" e "vengar la yra que no pude". Recorre também à aliteração do "g": gloria, agora, vengar, para marcar o ritmo e sonoridade do seu discurso.

Em contrapartida, Celestina interage ríspidamente, empregando um refrão de mal agouro, "¡Landre me mate”, para causar o efeito de que quer evitar o confronto fingindo não saber o motivo da ira de Sempronio: "si no me espanto en verte tan fiero! Creo que burlas. Dímelo agora, Sempronio, tú, por mi vida.¿Qué os ha passado?”

A réplica de Sempronio faz uso de eufemismo para não dizer diretamente que fará uso da força contra uma mulher: "mostrar otro semblante que con los hombres" e “con los que poco pueden" e, desse modo, Rojas desvela que o fim do diálogo se 
aproxima porque não haverá acordo entre os interlocutores. $O$ autor revela a real posição de Celestina como interlocutora neste discurso: é uma mulher, velha e mais fraca fisicamente que seu enunciador, Sempronio. A hipérbole referida ao estado em que se encontra Sempronio - "sin seso vengo, desesperado" e "yra y todo enojo" — já anuncia a tragédia que se seguirá.

A réplica de Sempronio continua com uma série de enumerações iniciadas por dois pontos que, como enunciador do discurso, se utiliza deste artifício para enumerar as várias justificativas da necessidade de cobrar a parte do dinheiro que lhe corresponde do negócio com Celestina. Nela, faz mais de uma série de elipses, julgando desnecessárias para fazer-se entender por sua enunciatária: "Traygo, señora, todas las armas despedaçadas: el broquel" (elipse) "sin aro; (elipse de "traygo") la espada, como sierra" (comparação); (elipse de "traygo") "el caxquete abollado en la capilla."

Recorre à hipérbole para enfatizar, não as armas e roupas despedaçadas, mas sim causar efeito de sentido estratégico para cobrar a sua parte do negócio: "Que no tengo con qué salir un passo con mi amo, quando menester me aya; que quedó concertado de yr esta noche que viene a verse por el huerto."

A insistência de Sempronio pretende causar um efeito de sentido verdade, pois, é sabido que ele deseja que seja feita a divisão dos ganhos do negócio com Celestina e Pármeno. Por isso, o personagem insiste com uma pergunta retórica "Pues, ¿comprarlo de nuevo?" e faz uso do recurso da metonímia “¡No mando un maravedí en que caya muerto!", maravedi, moeda da época, como sinônimo de dinheiro.

Celestina se arrisca impositivamente no desejo de sucesso. Coloca em risco a eficácia persuasiva ao passar por um espaço tensivo para modalizar o próprio "querer" e não entrar em conflito com o "dever", na tentativa de sair desse embate. Ela não abre concessões, por isso não amaina as hostilidades de Sempronio. A velha passa do limite entre o diálogo e a discussão. Para manter o diálogo com os criados ela deveria se abstrair da sua verdade e se abrir para a verdade do outro e, assim, continuaria construindo seu discurso em função dos valores coletivos. Mais que aprender a ver além dos seus julgamentos que condicionam as suas atitudes e limitam a capacidade de ouvir os outros, Celestina deveria ter procurado aumentar o grau de isenção em relação aos seus julgamentos, assim como o faz uma observadora neutra, para compreender os novos valores dos seus interlocutores diante das novas circunstâncias: Calisto lhe pagara com a corrente de ouro; entretanto, ela quer fazer prevalecer a sua verdade que, além de ter estado ocultada, somente agora, diante de uma discussão, se faz evidente. A velha 
não equilibra o questionamento dos criados com a sua defesa própria, o que sustentaria a base do diálogo. Ao contrário, ela fragmenta o desejo de Sempronio e Pármeno, se desvia da ligação que há entre a sua verdade e a deles, se defende em lugar de procurar compartilhar um novo significado para o acordo. A discussão entre Celestina e os criados tem início quando ela passa a defender os seus pressupostos individuais abertamente, abusando, portanto, da relação de dominação que vinha mantendo na obra. Ela se esquece da importância da neutralidade naquela circunstância cuja visão de cada um é uma perspectiva única, e não global, de uma realidade mais ampla, o que não favorece o diálogo para um novo entendimento comum.

Celestina persiste em fazer com que o criado desista da sua intenção de cobrar o acordo de dividir o dinheiro com a ela: "Pídelo, fijo, a tu amo, [...]".

A retomada da representação de Calisto dentro da hierarquia social favorece à elipse de pessoa "pues en su" (de Calisto) "servicio se gastó y quebró" (elipse de objeto: as armas e roupas), "pues en su servicio se gastó y quebró". "Pues” (anáfora) "sabes que es persona" (antonomasia de Calisto) "que luego lo" (elipse) "complirá; que no es de los" (elipse de "os amos") "que dizen: vive comigo y busca quien te mantenga" (paráfrase). "Él es tan franco que te dará para esso" (elipse de "armas") "y para más" (elipse de "tudo o mais"). Essa sequência de elipses evidencia a interação entre Celestina e seus interlocutores, a pesar das discordâncias de opiniões.

No Ato I, paradoxalmente, a velha mediadora, para conquistar Pármeno, já havia empregado o argumento de que o amo não se importa como seus criados:

[...] hasta en ello haver otro consejo mío; pero no con necia lealdad, proponiendo firmeza sobre lo movible, como son estos señores deste tiempo [...] dexa los vanos prometimientos de los señores: los quales desechan la substância de sus siruientes con huecos e vanos prometimientos. Como la sanguijuela saca la sangre, desagradescen, injurian, olvidan servicios, niegan galardón. (Cena 10, p.169)

Ao contrário, nessa nova circunstância, Calisto é um amo prestativo, porque lhe é conveniente nesse momento. A estratégia argumentativa pelo paradoxo causa mais ira em Sempronio que, ao reconhecê-la, replica "- ¡ $\mathrm{Ha}_{i}$ ”, onomatopeia que demonstra irritação. O criado procura apoio nas intenções de Pármeno e, para isso, passa a ser seu porta-voz: "Trae también Pármeno perdidas las suyas" (elipse: armas); “a este cuento, en armas se le yrá su" (elipse: Calisto) "hazienda".

Sempronio emprega os mesmos recursos argumentativos que a velha mediadora, a pergunta retórica: “¿Cómo quieres que le sea tan importuno en pedirle más de lo que 
él de su propio grado haze, pues es arto?" O destinatário que emprega as mesmas estratégias antes usadas pela principal enunciadora nos leva a reflexionar que a lógica leva à ideia de que se Sempronio vem depois de Celestina, portanto ele é sempre o efeito e ela é sempre a causa, em uma análise mais simples, porém, na prática, essa posição gera a crença errônea de que entre causas e efeitos existe sempre uma contiguidade ou uma proximidade muito estreita. Se considerássemos unicamente essa concepção responsável pelo imediatismo, dificultaríamos e muitas vezes impediríamos a compreensão de fenômenos complexos ${ }^{38}$ como os de natureza bio-psicossocial dos criados. Não reconheceríamos a crise dos valores medievais, não permitiríamos que o autor recriasse novos efeitos de sentido nas vozes dos personagens e não demonstrasse a sua crítica social diante da sociedade em que vive.

Sempronio insiste com as frases retóricas: "no digan por mí que dándome un palmo pido quatro" para buscar respaldo no senso comum - "no digan por mí" para o seu argumento de autoridade.

A repetição também é um recurso para buscar aceitação da sua interlocutora, por isso o criado reforça com a anáfora/ aliteração "dionos": "Dionos las cient monedas, dionos después la cadena". Mais que um reforço, Sempronio pretende deixar claro que a doação foi para os três sócios do negócio com Calisto: ele próprio, Pármeno e Celestina.

A expressão popular: "a tres tales aguijones no terná cera en el oýdo" costaría ese negócio" é empregada pelo criado para deixar claro o efeito de sentido verdade que ele não recorrerá a Calisto para conseguir mais dinheiro porque ele já os recompensara quando deu as cem moedas e a corrente de ouro para todos.

Sempronio prossegue com o seu turno de voz para exigir da interlocutora a razoabilidade necessária a todo acordo: "Contentémonos con lo" (elipse) "razonable; no lo" (elipse) "perdamos todo por querer más de la razón”. Para confirmar o já afirmado antes em busca de uma maior aceitação, o criado emprega o argumento de autoridade ao apelar ao senso comum, o refrão "que quien mucho abarca, poco suele apretar."

Entretanto, Celestina não está acostumada a ser destinatária, não negocia seus propósitos; a velha mediadora amorosa não procura um novo significado para o acordo

${ }^{38}$ Pesquisamos sobre o pensamento complexo no acesso em novembro de 2010 à página do prof. Humberto Mariotti sobre Complexidade e pensamento complexo: breve introdução e desafios atuais in

http://api.ning.com/files/S4Fa15pHbggJI7UgeoRWEKOd3gg4wKHInUumxfdRUbqynls9YLhpb cRcIvy58Gsp6loQ1EuZ1HHZB46KTIIF*4XgBrPE68n0/ComplexidadeMariotti.pdf

${ }^{39}$ Essa expressão popular diz que Calisto terá de vender até a cera do ouvido se os criados lhe pedem mais dinheiro do que ele já ofereceu. 
diante das novas circunstâncias, que são as mudanças do éthos dos seus interlocutores. Eles tentam negociar come la um novo acordo, ao que ela responde com ironia: "¡Gracioso es el asno!”

Ela emprega os mesmos recursos que vinham dando bons resultados persuasivos ao apelar para o argumento da experiência: "por mi vegez, que si sobre comer fuera, que dixera que habíamos todos cargado demasiado". Parafraseando, ela diz que se Sempronio tivesse dito isso depois de comer, ela pensaría que era porque tinham bebido muito vinho. Essa frase reforça a ironia de que só bêbado Sempronio poderia fazer esse pedido absurdo. Efetivamente, essa frase agride a face do interlocutor, o que impede que cheguem a algum acordo.

Celestina não trabalha com alteridade, não adapta seu jogo ao persistir com a dominação pelo poder da experiência adquirida pelos anos de vida. Ela prefere desqualificar seu interlocutor em lugar de procurar a adesão dos espíritos. Para procurar aceitação da sua posição de poder, emprega uma sequência de perguntas retóricas: “Estás en tu seso, Sempronio? ¿Qué tiene que hazer tu galardón con mi salario, tu soldada con mis mercedes? ¿Só yo obligada a soldar vuestras armas, a cumplir vuestras faltas?"

Com o contraste dos possessivos "tu” versus "mis": "tu galardón con mi salario, tu soldada con mis mercedes," a interlocutora Celestina aumenta a distância do seus destinatários, Sempronio e Pármeno, e consequentemente procura o campo da controvérsia e se afasta da possibilidade de um acordo. A oposição entre o que ela acredita ser seu direito no negócio e o que ela diz ser dos seus sócios é enfatizada pela figura sintática elipse: “¿Qué tiene que hazer tu galardón con mi salario, (¿qué tiene que hazer) tu soldada con mis mercedes?"

Torna-se mais clara a intenção da velha em separar o que é dela por direito e o que é dos criados quando reitera: “¿Só yo obligada a soldar vuestras armas, a cumplir vuestras faltas?".

O leitor pode perceber o prenúncio da morte de Celestina nessa afirmação retórica: "aosadas, que me maten" que parafraseamos em que ela ousaría apostar na sua vida. Reconhecemos mais um erro de estratégia porque a circunstância não pede ousadia e sim humildade do enunciador para negociar um novo significado para o acordo. 
O emprego das frases condicionais - "si no te has asido a una palabrilla que te dixe el otro día viniendo por la calle"- nesse contexto nos permite verificar que, a pesar de reconhecer o acordo, não o cumprirá conforme o combinado.

Celestina prefere o diminutivo "palabrilla" para empregar como recurso de ironia de valor depreciativo e, portanto, tirar a importância do que foi dito, reforçado pela situação rotineira de "el otro día viniendo por la calle", ou seja, um dia qualquer em uma rua qualquer.

Para anunciar a mudança de enunciadora para narradora de um fato que ocorreu consigo mesma, em discurso de estilo indireto, Celestina recorre ao sinal de pontuação, dois pontos: "te dixe [...]: que quanto yo tenía era tuyo, y que en quanto pudiesse con mis pocas fuerças jamás te faltaría, y que, si Dios me diesse buena manderecha con tu amo, que tú no perderías nada". Os verbos que reconhecidamente foram ditos por ela estão conjugados em tempo e modo condicional - "pudiesse", "faltaría", "diesse", "perderías"- porque refletem que essa narração não é o reconhecimento de que negociará o acordo dialogando com os seus interlocutores, mas sim que ela proporá as novas bases do acordo que lhe convém:

Pues ya sabes, Sempronio, que estos ofrescimientos, estas palabras de buen amor, no obligan. No ha de ser oro quanto reluze; si no, más barato valdría. Dime, ¿estoy en tu coraçon, Sempronio? Verás si, aunque soy vieja, sí acierto lo que tú puedes pensar. Tengo, hijo, en buena fe, más pesar, que se me quiere salir esta alma de enojo.

Retomando os clássicos, no De oratore de Cícero, redigido em 55 a.C., insistimos no fato de ser necessário que o éthos não seja um fingimento e, sim, uma construção simultânea do enunciador e da pessoa fora do discurso. Nesse sentido temos uma controvérsia entre Celestina como enunciadora e Celestina como sócia traidora:

Outras qualidades do orador somam-se ao efeito produzido: a doçura da voz, o ar do semblante, a amenidade da fala, a impressão de que, se ele se deixa levar por um ataque inflamado, é contra sua vontade. É muito fácil dar a ver as marcas de um humor dócil, de uma alma generosa, boa, sensível, acolhedora, protegida contra os desejos cobiçosos. Tudo o que indica a lisura, a modéstia, um caráter isento de amargura e de furor, inimigo dos litígios e das controvérsias, atrai a benevolência e indispõe contra os que não têm essas qualidades (CÍCERO, Livro II, XLII: 182)

A persuasiva enunciadora por excelência, Celestina, está no auge do embate com seus destinatários e, para desviar-se do confronto, escolhe a saída argumentativa da falácia: 
Di a esta loca de Elicia, como vine de tu casa, la cadenilla que traxe, para que se holgasse con ella, y no se puede acordar dónde la puso. Que en toda esa noche ella ni yo no avemos dormido sueño, de pesar. No por su valor de la cadena, que no era mucho, pero por su mal cobro della. Y de mi mala dicha entraron unos conocidos y familiares míos en aquella sazón aquí. Temo no la ayan levado diziendo: "si te vi, burléme" etc.

No momento em que Pármeno e Sempronio vão à casa de Celestina para repartir o butim de Calisto, a ameaçam com espalhar publicamente sua verdadeira identidade: "No quieras que descubra quién tú eres". Ao que Celestina responde indignada formulando um parlamento no qual, pela única vez na obra, se identifica claramente com o conteúdo das palavras que profere, isto é, um dos raros momentos da tragicomédia em que Celestina fala com franqueza quase absoluta, e sobre esta verdade apoia a força das suas palavras, de modo tão firme quanto desafiante. Ela justifica e defende a moral sobre a que, à margem de qualquer outro imperativo de ordem transcendente, fundamenta suas próprias formas de conduta:

CELESTINA. - ¿Quién só yo, Sempronio? ¿Quitásteme de la putería? Calla tu lengua; no amengues mis canas, que soy una vieja qual Dios me hizo, no peor que todas. Vivo de mi oficio como cada qual oficial del suyo, muy limpiamente. A quien no me quiere, no le busco. De mi casa me vienen a sacar, en mi casa me ruegan. Si bien o mal vivo, Dios es el testigo de mi coraçón. Y no pienses con tu yra maltratarme, que justicia ay para todos, a todos es ygual. Tan bién seré oýda, aunque mujer, como vosotros muy peynados. Déxame en mi casa con mi fortuna. Y tú, Pármeno, ¿piensas que soy tu cativa, por saber mis secretos y mi vida passada y los casos que nos acaescieron a mí y a la desdichada de tu madre? ¡Y aun assí me tratava ella, quando Dios quería.

As perguntas retóricas “¿Quién só yo, Sempronio? ¿Quitásteme de la putería?” revelam o tom de indignação de Celestina que se sente menosprezada por quem acreditava ser seu aliado e, sendo mais velha, não acredita ser diferente de outra anciã: "no amengues mis canas, que soy una vieja qual Dios me hizo, no peor que todas.".

Ao mencionar Claudina: "Y tú, Pármeno, ¿piensas que soy tu cativa, por saber mis secretos y mi vida passada y los casos que nos acaescieron a mí y a la desdichada de tu madre? ¡Y aun assí me tratava ella, quando Dios quería”, Celestina desperta uma reação agressiva do criado que se expressa vulgarmente: "no me hinches las narizes", adequado com a sua condição social: "no me hinches las narizes con essas memorias; si no, embiarte he con nuevas a ella, donde mejor te puedas quexar".

Em tom ameaçador "si no, embiarte he con nuevas a ella", Pármeno se equipara a Sempronio em agressividade e se justifica "donde mejor te puedas quexar" demonstrando o seu anseio de matá-la. 
¡Elicia, Elicia! ¡Levántate dessa cama, da acá mi manto presto, que, por los sanctos de Dios, para aquella justicia me vaya, bramando como una loca! ¿Qué es esto? ¿Qué quieren decir tales amenazas en mi casa? ¿Con una oveja mansa tenés vosotros manos y braveza? ¿Con una gallina atada? ¿Con una vieja de sesenta años? ¡Allá, allá con los hombres como vosotros! Contra los que ciñen espada mostrá vuestras yras, no contra mi flaca rueca.

Desesperada, Celestina pede ajuda a Elicia “¡Elicia, Elicia! ¡Levántate dessa cama, da acá mi manto presto" e roga a Deus "por los sanctos de Dios".

A velha fala em justiça - "para aquella justicia me vaya"- porque, ao se sentir ameaçada, tenta criar o efeito de sentido-verdade para retomar o domínio da situação. Com a sequência de perguntas retóricas, “¿qué es esto? ¿Qué quieren decir tales amenazas en mi casa? ¿Con una oveja mansa tenés vosotros manos y braveza? ¿Con una gallina atada? ¿Con una vieja de sesenta años?”, não espera resposta dos nervosos interlocutores e, sim, através de figuras de palavras, pretende com que eles retrocedam e ela volte a recuperar o espaço perdido pela desconfiança no seu éthos. Se a idade pesava a seu favor nos argumentos de autoridade, agora ela usa os seus sessenta anos como argumento de defesa contra os ataques dos jovens sócios Sempronio e Pármeno. Da mesma forma que ser mulher nunca fora impecilho para o poder, agora é argumento machista pela oposição espada e rueca: “AAllá, allá con los hombres como vosotros!”. Contra los que ciñen espada mostrá vuestras yras, no contra mi flaca rueca”. Celestina sempre foi a principal enunciadora porque detinha o poder através da sabedoria, nunca tinha se considerado inferior para fazer uso de argumentação: "señal es de gran covardía acometer a los menores y a los que poco pueden".

A sua estratégia através de metáforas persiste porque visa persuadir pela insistência e repetição:

\footnotetext{
Las sucias moxcas nunca pican sino los bueyes magros y flacos; los guzques ladradores a los pobres peregrinos aquexan con mayor ímpetu. Si aquella que allí está en aquella cama me oviesse a mí creýdo, jamás quedaría esta casa de noche sin varón, ni dormiríemos a lumbre de pajas, pero por aguardarte, por serte fiel, padescemos esta soledad. Y, como nos veys mujeres, habláis y pedís demasías. Lo qual, si hombre sintiéssedes en la posada, no haríades; que, como dizen: "el duro adversario entibia las yras y sañas".
}

Estrategicamente se coloca na posição de frágil "con una oveja mansa [...] con una gallina atada [...] con una vieja de sesenta años [...] buyes magros y flacos", animais que simbolizam a sua própria animalização e adjetivos como "mansa", "atada" e "magros flacos" mostram o efeito de sentido inverosímil à imagen do éthos que ela sempre aparentou: a que detém poder pela sabedoria. 
A oposição entre "espada" e " rueca" e "los guzques ladradores versus pobres peregrinos" se dá entre os mais e os menos poderosos e, ao final, ela coloca a oposição entre homens e mulheres: "si aquella (elipse de Elicia) que allí está en aquella cama me oviesse a mí creýdo, jamás quedaría esta casa de noche sin varón", "como nos veys mujeres, habláis y pedís demasías" e "si hombre sintiéssedes en la posada, no haríades". A essa altura da discussão, Celestina menciona fidelidade entre homem e mulher, entre Elicia e Semproinio: "ni dormiríemos a lumbre de pajas, pero por aguardarte, por serte fiel, padescemos esta soledad".

A reação de Sempronio é imediata e implacável: “¡O vieja avarienta, garganta muerta de sed por dinero!” A pergunta retórica “¿no serás contenta con la tercia parte de lo ganado?” tem réplica certa: “tú compliras lo que tú prometiste, o se complirán oy tus días".

A resposta de Celestina também é rápida e certeira, embora se preocupe em amainar os ânimos de Sempronio. Os imperativos "vete", "no dé", "no me hagáys" e "no queráys" revelam o tom áspero e a corporalidade de quem está muito pressionada, a ponto de recorrer a terceiros:

¿Qué tercia parte? ¡Vete con Dios de mi casa, tú! Y essotro no dé vozes, no allegue la vezindad. No me hagáys salir de seso. No queráys que salgan a plaza las cosas de Calisto y vuestras.

Longe de se preocupar com a sua imagen diante das pessoas da cidade, Sempronio está dominado pelo sentimento de vingança: "da vozes o gritos, que tú compliras lo que tú prometiste, o se complirán oy tus días”. Emprega o jogo de palabras entre o que cumprir: "lo que tú prometiste" versus "tus días"

Quando Elicia intervem no diálogo já é tarde para evitar a morte da "madre": “iMete, por Dios, el espada! Tenle, Pármeno, tenle; no la mate esse desvariado”.

A cenografia final tem características grotescas que revelam, não só a esperada punição anunciada no Incipit à alcoviteira e aos falsos criados, mas também a crítica à sociedade que valoriza o dinheiro, a fortuna que levam as pessoas à cobiça e à ganância.

CELESTINA - ¡Justicia, justicia, señores vezinos! ¡Justicia, que me matan en mi casa estos rufianes!

SEMPRONIO - ¿Rufianes, o qué? ¡Espera, doña hechizera, que yo te haré yr al infierno con cartas!

CELESTINA - ¡Ay, que me ha muerto! ¡Ay, ay! ¡Confessión, confessión! 
Se por um lado a confissão é uma maneira de receber o perdão para os pecados que vinha cometendo e, sobretudo, o da avareza, Celestina tem um desejo de contrição ao representar arrependimento, não por medo do castigo divino, mas sim por medo do castigo humano, muito embora, àquela altura da discussão, já fosse tarde. Lembramos que sob a visão cristã, ela precisa se confessar, se arrepender e pagar uma penitência para que sua alma seja purificada e obtenha o perdão. Visto por outro lado, dentro do individualismo, um dos principais valores do Renascimento do século XVI, os seguidores do protestantismo de Lutero conversam diretamente com Deus ${ }^{40}$ assim como o faz o ideário burguês direta e individualmente. Anacrônica e paradoxalmente um dos preceitos da Igreja Católica que "é mais fácil um camelo entrar por um buraco de uma agulha que um rico entrar no reino dos céus", a cobiça é uma prática condenada no seio da Igreja Católica Romana e todo ganho deve ser partilhado com ela.

Pármeno incentiva Sempronio a acabar de matar a velha: “¡Dale, dale, acábala, pues començaste, que nos sentirán! ¡Muera, muera! ¡De los enemigos, los menos!"

A revolta de Elicia se confirmará nos capítulos seguintes com a sua trama de vingança sobre Calisto: “ $\mathrm{OO}$ crueles enemigos! ¡En mal poder os veáys! ¡Y para quién tovistes manos! ¡Muerta es mi madre y mi bien todo!”

A cena termina com a fuga frustrada dos assassinos:

SEMPRONIO - ¡Huye, huye, Pármeno, que carga mucha gente! ¡Guarte, guarte, que viene el alguazil!

PÁRMENO - ¡O pecador de mí! ¡Que no ay por dó nos vamos, que está tomada la puerta!

SEMPRONIO - ¡Saltemos destas ventanas. No muramos en poder de justicia.

PÁRMENO - ¡Salta, que tras ti voy!

\section{Conclusão}

A desconstrução do personagem Celestina no discurso pode ser entendida e explicada por várias teorias, embora nenhuma preencha todas as nossas indagações e encerre a questão sobre o mecanismo de causa e efeito criado por Rojas que tem como consequência a morte dos personagens.

${ }^{40}$ O Protestantismo descarta a presença das imagens de santos e a necessidade de mediador para a confissão auricular dos pecados para autoridades eclesiásticas como forma de obter a remissão destes. Entretanto, o Protestantismo histórico adota a confissão coletiva durante o culto, sendo opcional a confissão privada. 
Primeiramente, para explicar o fracasso de Celestina como enunciadora nos baseamos no eu bakhtiniano, que não é monádico e nem autônomo, existe a partir do diálogo com os outros eus e necessita da colaboração de outros para definir-se e ser "autor" de si mesmo. Até então, nos discursos anteriores à falta de acordo com os seus principais interlocutores, Sempronio e Pármeno, Celestina tomada como sujeito baktiniano, é solidária às alteridades de seu discurso que é concebido em uma partição de vozes concorrentes. Sua palavra se transforma dialogicamente, para tornar-se "palavra da pessoa-alheia", com a ajuda de outras "palavras do outro", e depois, palavra pessoal. (Bakhtin, 1992b:405-6).

Entretanto, com a falta de diálogo no discurso do outro, o personagem perde a consciência de que o que diz não se apoia mais nos valores dos criados. A perda do duplo deslocamento, aquele que se ancora na consciência da palavra que só se realiza apoiando-se no discurso do outro, nos remete à relação de causa e efeito (Lida, 1968: 90 e Gilman, 1972:337). Desde o assentimento prévio à falta de acordo, o desencadeamento da relação de causa e efeito se justifica na coerência interna em que nada é supérfluo e arbitrário. Inclusive as premonições e avisos se convertem em um sentido prático na obra. A destruição física e espiritual dos personagens já era prevista: a corrente de ouro é a que causa a ganância de Celestina e a cobiça dos criados e, como ela se nega a procurar um novo entendimento que compartilhe um significado comum aos três, passa do diálogo à discussão, seguida de violência e morte.

O auditório de Celestina é o conjunto daqueles a quem ela influência através da sua argumentação, ou seja, os seus assassinos Sempronio e Pármeno, Melibea e Calisto. Seu auditório é fruto de uma construção consciente por parte da nossa oradora que tem um objetivo: adquirir riqueza para sobreviver durante a sua velhice e continuar gozando do prazer à mesa. Ela conhece quem a ouve, identifica suas condicionantes sociais e suas paixões. Em função desse conhecimento, influência o grupo por meio de técnicas externas e internas ao próprio discurso. Neste processo, auditório e oradora se transformam dialeticamente, quando Celestina se nega a se transformar, desqualifica seu discurso e desconstrói seu éthos de enunciadora persuasiva.

Quanto à dimensão estética, a escolha das figuras, sintáticas e semânticas, a modalização relativa às formas de dizer e a performatividade, relativa à dimensão acional da linguagem, explicam a construção do éthos da enunciadora e a desconstrução se dá quando essas escolhas não persuadem os destinatários a mudar seus valores. 
A morte de Celestina é uma das consequências imediatas da falta de acordo com o seu auditório. Dentro dessa perspectiva, retomamos o raciocínio retórico-dialético sobre a noção de acordo segundo a ótica cartesiana: todo acordo é uma consequência natural de uma proposição verdadeira - o que importa é a verdade, e se a proposição é verdadeira o acordo virá como uma consequência lógica (PERELMAN, 1988, p.137). Entretanto, a velha não modaliza com os valores dos criados ao se preocupar prioritariamente com a sua crença e não com a verdade, para isso manipula de forma desenfreada e imoral os demais personagens através de técnicas argumentativas com o intuito de subverter a verdade em benefício próprio. Seus argumentos não são válidos porque as premissas não são verdadeiras: um dos motivos é a ausência de modéstia, cujo traço também está na sociedade, na qual Celestina se apresenta como "a dona da verdade".

A desqualificação do personagem no discurso se dá ao revelar o seu microdiálogo. Nele, o seu discurso interior desvela a sua consciência desintegrada e também seu éthos efetivo para fazer-se ouvir a voz da sua consciência. No discurso que precede a sua morte, Celestina se limita a relatar experiências, mencionar fatos e enunciar certas verdades, ou seja, a velha negligencia os contra-argumentos do seu auditório particular, por isso não obtém a adesão dos espíritos necessária para chegar a um acordo com os criados, que vieram a ser seus assassinos.

Embora não tenha obtido a adesão dos seus comparsas, segundo aponta Chaïm Perelman (1987:239), “o valor e a qualidade de uma argumentação não pode medir-se unicamente pelo efeito obtido: ela depende ainda e essencialmente da qualidade do auditório que se consegue ganhar através do seu discurso". Celestina, para evitar a sua morte grotesca, poderia ter se inclinado diante a evidência da verdade universal - os interlocutores são os sócios que querem sua participação no negócio - e não diante a da sua verdade particular — a de enriquecer-se —, visto que a convicção advém do confronto rigoroso do pensamento do seu auditório com o do orador. Entretanto o autor escolhe exibir a degradação social e moral da sociedade retratada nas atitudes do personagem.

Por último, concordamos com Lida de Malkiel (1962: 533) quando afirma:

[...] la falla decisiva de Celestina: no falla artística en el trazado de su carácter, sino el muy artístico acierto en la representación del error de conducta, inherente a toda criatura trágica, que reduce su inteligencia y su saber a las falibles dimensiones humanas. Porque aquí su inteligencia y su saber no encauzan su codicia; sin disimulo niega la participación tantas veces prometida, y anula sus promesas como meras fórmulas de cortesía. 
A verossimilhança do personagem faz de Celestina tão humana a ponto de carregar consigo os vícios como a avareza, a cobiça, a mentira e a traição — fatores sociais e morais que corrõem a sociedade - que, ao contribuírem para o seu defecho, destroem também o sentimento burguês de acumular riqueza.

Embora reconheçamos que a existência do ser ficcional dialogue com o meio social e as características do éthos discursivo do personagem reflitam as da sociedade, podemos atribuir às características internas ao personagem o movimento de construção e desconstrução do seu discurso. Não podemos inferir a morte dos personagens a um fator externo, apesar do desejo de Rojas em punir alcoviteiras e falsos criados pelos enganos aos loucos apaixonados. 


\section{CONCLUSÃO}

"Encontrei hoje em ruas, separadamente, dois amigos meus que se haviam zangado um com o outro. Cada um me contou a narrativa de por que se haviam zangado. Cada um me disse a verdade. Cada um me contou as suas razões. Ambos tinham razão. Não era que um via uma coisa e outro outra, ou que um via um lado das coisas e outro um outro lado diferente. Não: cada um via as coisas exatamente como se haviam passado, cada um as via com um critério idêntico ao do outro, mas cada um via uma coisa diferente, e cada um, portanto, tinha razão.

Fiquei confuso desta dupla existência da verdade."

Fernando Pessoa 
Este trabalho reconheceu, primeiramente, que a persuasão é a principal característica do discurso de Celestina para alcançar seus objetivos pessoais e, segundo, que ela é um personagem que se constrói e se destrói em seu discurso e por intermédio dele. Para fundamentar nossa hipótese, investigamos o discurso do personagem em dois momentos: o eficaz e o pouco persuasivo.

A função de Celestina na obra é fundamentalmente a de facilitar a rendição amorosa de Melibea para a satisfação e deleite de Calisto e, uma vez cumprida essa função, o personagem não se sustenta mais no enredo. Em consequência, seus argumentos não persuadem mais porque não se adaptam no sentido de reconhecer os novos valores dos seus interlocutores, que a ameaçam e colocam fim ao diálogo.

Através do discurso, o personagem oculta a sua verdade e o seu propósito pessoal em conseguir dinheiro para sobreviver. Para tanto, além de cobiçar o pagamento de Calisto pelo seu trabalho, fruto de alguns dos seus ofícios, precisará do apoio de aliados, os quais não os julga merecedores de pagamento porque é avarenta. Esse discurso só resiste enquanto a sua verdade pessoal não é revelada diante dos seus aliados. Dentro da complexidade do personagem reconhecemos que os vícios condenados pelo cristianismo - a inveja, a soberbia, a luxúria, a cobiça e a avareza estão subvertidos por mentira e fingimento para revelar um éthos de confiabilidade. Contudo, acreditamos que o principal traço do personagem está na cultura humanística aflorada pelo autor por meio das paixões humanas. Os motores das ações da velha alcoviteira são sentimentos como a cobiça, que está relacionada com o movimento de ascenção da construção do personagem no seu discurso, e a avareza, relativa à queda do desempenho do razoamento do personagem.

O movimento de construção ou ascensão e desconstrução ou desqualificação de Celestina no seu discurso está diretamente associado à relação de causa e efeito das ações e pensamentos do personagem. Muito embora a morte não seja o fim do tema celestinesco interno e externamente à obra, temos, por um lado, Pármeno e Sempronio perpetuando-se em Sosia e Tristán, envolvidos com as prostitutas, uma das quais será a discípula das artes de Celestina, Areúsa; por outro temos Pleberio, um burguês arruinado por não ter para quem deixar seus bens acumulados e sua esposa, Alisa, que permanece semimorta. Contudo, Sosia e Tristán não podem permanecer criados sem o amo; Areúsa e Elicia perdem a "madre" que as protegia; o burguês não tem mais motivação para continuar acumulando riqueza. Portanto, "nada ha quedado en pie en la ciudad vacía" (GONZÁLEZ, 2009, p.20) de tipos sociais e de relações interpessoais. O 
mecanismo de subversão de Celestina aniquila de todas as formas os habitantes representantes das castas sociais da simbólica cidade pré-burguesa de Rojas.

Rojas, ao reduzir o personagem Celestina à sua existência, apoiou-se em Timóteo 6:10, que afirma que "a cobiça é a raiz de todos os males; e nessa cobiça alguns se desviaram da fé, e se traspassaram a si mesmos com muitas dores" o que o motiva a desenvolver em Celestina um discurso carregado de fontes cujos argumentos de autoridade citam personalidades, como Petrarca, Sêneca, Aristóteles e Heráclito e figuras de linguagem, fontes para amparar a ambição desmedida de conquistar o prêmio com Calisto.

A palavra ambição está diretamente relacionada à cobiça que, por sua vez, é o desejo veemente de conseguir alguma coisa, a ânsia de honras ou riquezas, a avidez, a concupiscência. Da palavra cobiça podemos chegar à palavra cupido, cujas características se aproximam das da alcoviteira Celestina, e significava também devasso, corrupto, libertino, lascivo e luxurioso.

O discurso de Celestina deixa de ter o efeito de sentido verdade uma vez alcançados seus objetivos pessoais os quais, como fatores da história social agem fortemente sobre ele e assim, a sua característica avarenta se sobressai para justificar o seu fim. Ao não dividir seus ganhos nem sob a ameaça de morte, o personagem não tem um discurso que o impeça de ser assassinado. Com isso, Rojas converte a avareza ou a ganância em um traço dramático no personagem porque o leva às consequências trágicas como a violência seguida de morte. A princípio, a avareza é um vício humano há muito explorado pelos autores do teatro romano como uma característica da comicidade dos personagens, sobretudo dos alcoviteiros. Entretanto, Rojas a subverte à tragédia. Lida de Malkiel (1962:558) afirma que "sólo Rojas percibió el potencial trágico de la avaricia de la alcahueta, hasta entonces entendida como rasgo humorístico inesencial"'. 


\section{ANEXOS}

\section{Sumário}

Anexo 1 - Corpus Texto 1

Acto I Escena 10

124

Anexo 2 - Texto Sêneca - Parte integrante da análise do Corpus Texto 1

Alia Senecae epistola de varietate lectionis 126

Uma outra carta de Sêneca sobre a diversidade

na leitura (versão por Stéfano Paschoal)

Una otra carta de Séneca sobre la diversidad

en la lectura (versão por Antonius Djacnov)

Anexo 3 - Corpus Texto 2

Acto XII Escena 9

131

Acto XII Escena 10

131 


\section{Anexo $1-$ Corpus Texto 1}

Acto I Escena 10

CELESTINA — ¡Mala landre te mate! ¡Y cómo lo dize el desvergonçado! Dexadas burlas y pasatiempos, oye agora, mi fijo, y escucha: que aunque a un fin soy llamada, a otro só venida; y maguera que contigo me aya fecho de nuevas, tú eres la causa. Hijo, bien sabes como tu madre, que Dios aya, te me dio viviendo tu padre, el qual, como de mí te fueste, con otra ansia no murió sino con la incertidumbre de tu vida y persona, por la qual absencia algunos años de su vejez sufrió angustiosa y cuydosa vida. Y al tiempo que della passó, embió por mí y en su secreto te me encargó y me dixo, sin otro testigo sino Aquel que es testigo de todas las obras y pensamientos, y los corazones y entrañas escudriña, al qual puso entre él y mí que te buscasse y allegasse y abrigase, y quando de complida edad fueses, tal que en tu vivir supieses tener manera y forma, te cubriesse a dónde dexó encerrada tal copia de oro y plata que basta más que la renta de tu amo Calisto. Y porque gelo prometí y con mi promesa llevó descanso y la fe es de guardar más que a los vivos a los muertos, que no pueden hazer por sí, en pesquisa y seguimiento tuyo yo he gastado asaz tiempo y quantía hasta agora, que ha aplazido a Aquel que todos los cuydados tiene y remedia las justas peticiones y piedosas obras endereça, que te hallase aqui, donde solos ha tres dias que se que moras. Sin duda dolor he sentido: porque has por tantas partes vagado e peregrinado: que ni has hauido prouecho, ni ganado debdo ni amistad; que, como Seneca nos dize, los peregrinos tienen muchas posadas y pocas amistades porque en breve tiempo con ninguno no pueden firmar amistad; y el que está en muchos cabos no está en ninguno; ni puede aprouechar el manjar a los cuerpos que, en comiendo, se lanza, ni ay cosa que más la sanidad impida que la diuersidad y mudança y variación de los manjares; y nunca la llaga viene a cicatrizar en la qual muchas melezinas se tientan, ni conualesce la planta que muchas vezes es traspuest, ni ay cosa tan prouechosa que, en llegando, apriessa aproveche. Por tanto, mi hijo, dexa los impetus de la juuentud y tórnate, 
con la doctrina de tus mayores, a la razón. Reposa en alguna parte. ¿Y dónde mejor que en mi voluntad, en mi ánimo, en mi consejo, a quien tus padres te remetieron? Y yo, assí como verdadera madre tuya te digo, so las maldiciones que tus padres te pusieron si me fuesses inobediente, que por el presente sufras y siruas a este tu amo que procuraste, hasta en ello hauer otro consejo mío; pero no con necia lealdad, proponiendo firmeza sobre lo movible, como son estos señores deste tiempo. Y tú, gana amigos, que es cosa durable. Ten con ellos constancia. No vivas en flores. Dexa los vanos prometimientos de los señores, los quales desechan la substância de sus sirvientes con huecos y vanos prometimientos. Como la sanguijuela saca la sangre, desagradescen, injurian, olvidan servicios, niegan galardó. ¡Guay de quien en palacio enuejece! Como se escrive de la probática piscina, que de ciento que entravan, sanava uno. Estos señores deste tiempo más aman a sí que a los suyos, y no yerran; los suyos ygualmente lo deven hazer. Perdidas son las mercedes, las magnificencias, los actos nobles. Cada uno déstos cativan y mezquinamente procuran su interesse con los suyos; pues aquéllos no deven menos hazer, como sean en facultades menores, sino viuir a su ley. Dígolo, fijo Parmeno, porque este tu amo, como dizen, me parece rompenecios. De todos se quiere servir sin merced. Mira bien, créeme. En su casa cobra amigos, que es el mayor precio mundano; que con él no pienses tener amistad, como por la diferencia de los estados o condiciones pocas vezes contezca. Caso es ofrecido, como sabes, en que todos medremos y tú por el presente te remedies. Que lo ál que te he dicho guardado te está a su tiempo. Y mucho te aprouecharás siendo amigo de Sempronio.

PÁRMENO - Celestina, todo tremo de oírte. No sé qué haga. Perplexo estó. Por una parte, téngote por madre. Por otra a Calisto por amo. Riqueza desseo, pero quien torpemente sube a lo alto, más aýna caye que subió. No querría bienes mal ganados.

CELESTINA - Yo sí. A tuerto o a derecho, nuestra casa hasta el techo. 
Anexo 2 - Texto Sêneca - Parte integrante da análise do Corpus Texto 1

Alia Senecae epistola de varietate lectionis

Ex his quae mihi scribis, et ex his quae audio, bonam spem de te concipio, non discurris, nec locorum mutationibus inquietaris, aegri animi iactatio ista est. Primum argumentum bene compositae mentis existimo, posse consistere, et secum morari. Illud autem vide, ne esta lectio multorum autorum et omnis generis voluminum, habeat aliquid vagum et instabile. Certis ingenijs immorari et innutriri oportet, se velis aliquid trahere, quod in animo fideliter sedeat. Nusquam est qui ubique est. In peregrinatione vitam agentibus hoc evenit, ut multa hospicia habeant, nullas amicitias. Idem accidat necesse est eis qui nullius se ingenio familiariter applicant, sed omnia cursim et properanter transmittunt. Non prodest cibus, nec corpori accedit, qui statim sumptus emittitur. Nihil aeque sanitatem impedit quam remediorum crebra mutatio. Non venit vulnus ad cicatricem, in quo crebra medicamenta tentantur. Non convalescit planta quae saepius transfertur, nihil tam utile est, quo in transitu prosit. Distrahit animum librorum multitudo. Itaque cum legere non possis quantum habueris, sat est habere quantum legas. Sed modo, inquis, hunc librum evoluere volo, modo illum, fastidientis stomachi est multa degustare, quae ubi varia sunt et diversa, coinquinant non alunt. Probatos itaque semper lege, et si quando ad alios diverti libuerit, ad priores redi. Aliquid quotidie adversus paupertatem, aliquid adversus mortem auxilij compara, nec minus adversus ceteras pestes. Et cum multa percurreris, unum excerpe, quod illo die concoquas. Hoc ipse quoque facio, ex pluribus quae lego, aliquid apprehendo hodiernum, Hoc est, quod apud Epicurum nactus sum, soleo enim et in aliena castra transire, non tanquam transfuga, sed tanquam explorator. Honesta, inquit, res est, laeta paupertas. Illa vero non est paupertas si laeta est. Cui enim cum paupertate bene convenit, dives est, Non qui parum habet, sed qui plus cupit, pauper est. Quid enim referet quantum illi in arca, quantum in horreis iaceat, quantum pascat, au foeneret, se alieno imminet, si non acquisita, sed acquirenda computat? Quis sit divitiarum modus quaeris. Primus habere quod necesse est, proximus quod sat est. Vale. 
Uma outra carta de Sêneca sobre a diversidade na leitura (versão por Stéfano Paschoal ${ }^{41}$ ) $-2^{\mathrm{a}}$ Carta a Lucílio

O que tu me escreves e aquilo que ouço me fazem nutrir boas esperanças a teu respeito: tu não te dispersas e não te irritas com a mudança de teus domicílios, o que corresponderia à inconstância de um intelecto fraco. Julgo a melhor prova de um discernimento bem organizado poder ter uma posição e manter-se nela.

Vê o quão desorientada e instável é a leitura de muitos autores e de todo tipo de livros! Tu deves restringir-te a um número determinado de pensadores e nutrir-te deles, se quiseres tirar disto alguma coisa que seguramente se sedimente em teu intelecto. Quem está por toda a parte, não está em lugar algum. A quem passa sua vida andando a esmo em terras distantes, pode suceder que conheça muitas hospedarias, mas não conhecerá amigos. É exatamente isto o que necessariamente ocorre àqueles que não se aprofundam intelectualmente em nada, mas que correm os olhos por tudo, superficialmente e com pressa. O alimento do qual o corpo se desfaz - mal o tenha recebido — não é útil a nada e não se torna parte dele. Nada prejudica mais a saúde do que a frequente mudança de medicamentos. Não se cicatriza a ferida em que se experimentam continuamente novos remédios. Não se desenvolve a planta frequentemente mudada de lugar. Nada é tão útil a ponto de sê-lo apenas num momento de passagem. Muitos livros apenas dispersam o intelecto. Assim, se tu não podes ler o tanto de que gostarias de apossarte, é satisfatório que te apropries daquilo que lês. "Mas é que", tu dizes, "eu gostaria de ler agora este livro, depois aquele”. - Esta é a característica de um estômago mal acostumado: experimentar muitas coisas — porque são diferentes e muito variadas - apenas onera o corpo, mas não o sustenta. Por isso, lê sempre e tão somente os autores experimentados e, mesmo quando tu porventura desejares distrair-te com qualquer outra coisa, retorna a eles. Consegue a cada dia algo que te ajude a combater a pobreza, alguma coisa que te ajude a combater a morte e, exatamente da mesma forma, algo que combata todas as outras pragas. E mesmo que tenhas passado o dia todo lendo muita coisa, escolhe uma de que realmente possas

${ }^{41}$ Doutor em Língua e Literatura Alemã pela Universidade de São Paulo, professor de Língua Alemã do curso de Letras da UNIOESTE (Universidade Estadual do Oeste do Paraná), campus de Marechal Cândido Rondon — PR. 
apropriar-te. Eu mesmo faço isto. Do muito que leio, aprendo alguma coisa. Isto é o que descobri hoje em Epicuro - pois também estou acostumado a ir a lugares estranhos, não como desertor, porém como explorador: "A pobreza com a qual se vive satisfeito", diz ele, "é um estado honroso". - Logicamente, não é pobreza alguma aquela em que se vive bem, pois quando alguém se acomoda bem a ela, ele é rico. Não é pobre aquele que possui muito pouco, mas aquele que ambiciona mais. O que importa o quanto alguém tem no cofre ou o quanto há em seus armazéns, quanto gado ele apascenta ou quanto dinheiro ele empresta a juros, se ele ambiciona o alheio? Se ele não soma o que ganhou, mas o quanto ainda deseja ganhar? Tu queres saber a medida da riqueza? Primeiro, ter aquilo de que se necessita e, depois, aquilo que lhe basta. Adeus. 
Una otra carta de Séneca sobre la diversidad en la lectura (versão por Antonius Djacnov — 2009)

Por lo que me escribes y por lo que escucho, albergo buenas esperanzas respecto de tí: no te dispersas ni te inquietas por cambiar de lugar de vida. Tal agitación resultaría de un ánimo enfermizo: la primera muestra de un espíritu equilibrado es la la facultad de situarse y permanecer en sí mismo.

Por otra parte presta atención que tu afán de múltiples autores y de todo tipo de lecturas no conlleve algo de vago e inestable. Es el talento probado lo que debes alojar y nutrir para asentar lo fidedigno en tu espíritu. En ningún lado está aquel que está en todos lados. La vida de peregrinaje trae aperejada muchos anfitriones y ningún amigo. Lo mismo acontece inevitablemente a quien, en lugar de aplicarse a profundizar un autor de talento, sobrevuela varios agitada y precipitadamente.

No aprovecha ni nutre el cuerpo el alimento que ni bien consumido es regurgitado. Nada obsta más a la salud que el cambio frecuente de remedios, no cicatriza la herida en la que se ensayan curaciones ni crece el árbol que frecuentemente se trasplanta. Nada es tan perdurable que pueda aprovecharse simplemente de pasaje. Mantente alejado de plétora de libros: si no puedes leer todo lo que puedas poseer, suficiente te sea poseer lo que puedas leer.

A veces - dices - quiero hojear tal libro, a veces tal otro. Empalagarse con muchas cosas es lo propio de los estómagos hastiados. Lo mucho y lo muy diverso, no nutre: contamina. Cíñete a los genios reconocidos y si para distraerte te complaces con lecturas diversas, retorna siempre a los primeros. Emprende cotidianamente algo contra la pobreza, algo contra la muerte y no menos contra otras calamidades. Luego de andar camino, procúrate un extracto para reflexionar en dicho día.

Yo mismo hago tal cosa: de lo mucho que leo siempre retengo algún pasaje. El de hoy día proviene de Epicuro (suelo transitar en el campo adverso, pero no en tanto que tránsfuga sino como explorador): "honorable" — dice — "es la pobreza feliz".

Pero en tal caso, si feliz, no puede aquella denominarse pobreza: no es pobre aquel que poco posee, sino aquel que mucho ambiciona. ¿Qué importa, en efecto, cuánto se detiene en arcas, cuánto se acumula en graneros, el ganado que se posee o el dinero colocado a interés, si se codicia lo de otro, si no es lo que ya se tiene lo que cuenta sino aquello que se estima deber tener? 
Me preguntas cuál debería ser la medida de la riqueza: primero tener lo necesario, luego lo suficiente.

Que sigas bien. 


\section{Acto XII Escena 9}

PÁRMENO - ¿Adónde yremos, Sempronio? ¿A la cama a dormir o a la cozina a almorzar?

SEMPRONIO -Ve tú donde quisieres, que antes que venga el día quiero yo yr a Celestina a cobrar mi parte de la cadena. Que es una puta vieja; no le quiero dar tiempo en que fabrique alguna ruyndad con que nos escluya.

PÁRMENO -Bien dizes; olvidado lo avia. Vamos entramos, y si en esso se pone, espantémosla de manera que le pese. Que sobre dinero no ay amistad.

\section{Ato XII Escena 10}

SEMPRONIO - ¡Ce, ce! Calla, que duerme cabo esta ventanilla! Tha, tha! ¡Señora Celestina, ábrenos!

CELESTINA - ¿Quién llama?

SEMPRONIO - Abre, que son tus hijos.

CELESTINA - No tengo yo hijos que anden a tal hora.

SEMPRONIO - Ábrenos a Pármeno y Sempronio, que nos venimos acá almorzar contigo.

CELESTINA - ¡O locos traviesos! ¡Entrad, entrad! ¿Cómo venís a tal hora, que ya amanesce? ¿Qué havés hecho? ¿Qué os ha passado? ¿Despidióse la esperança de Calisto, o vive todavía con ella, o cómo queda?

SEMPRONIO - ¿Cómo, madre? Si por nosotros no fuera, ya andoviera su alma buscando posada para siempre. Que si estimarse pudiese a lo que de allí nos queda obligado, no sería su hazienda bastante a complir la debda, si verdad es lo que dizen, que la vida y persona es más digna y de más valor que otra cosa ninguna.

CELESTINA - ¡Jesú! ¿Qué en tanta afrenta os havés visto? Cuéntamelo, por Dios.

SEMPRONIO - Mira, que tanta que, por mi vida, la sangre me hierve en el cuerpo en tornarlo a pensar.

CELESTINA - Reposa, por Dios, y dímelo. 
SEMPRONIO - Cosa larga le pides según venimos alterados y cansados del enojo que havemos havido. Farías mejor en aparejarnos a él y a mí de almorzar; quiçá nos amansaría algo la alteración que traemos. Que cierto te digo que no querría ya topar hombre que paz quisiesse. Mi gloria sería agora hallar en quien vengar la yra que no pude en los que nos la causaron, por su mucho huyr.

CELESTINA - ¡Landre me mate, si no me espanto en verte tan fiero! Creo que burlas. Dímelo agora, Sempronio, tú, por mi vida. ¿Qué os ha passado?

SEMPRONIO - Por Dios, sin seso vengo, desesperado, aunque, para contigo, por demás es no templar la yra y todo enojo y mostrar otro semblante que con los hombres. Jamás me mostré poder mucho con los que poco pueden. Traygo, señora, todas las armas despedaçadas: el broquel sin aro; la espada, como sierra; el caxquete abollado en la capilla. Que no tengo con qué salir un passo con mi amo, quando menester me aya; que quedó concertado de yr esta noche que viene a verse por el huerto. Pues, ¿comprarlo de nuevo? ¡No mando un maravedí en que caya muerto!

CELESTINA - Pídelo, fijo, a tu amo, pues en su servicio se gastó y quebró. Pues sabes que es persona que luego lo complirá; que no es de los que dizen: "vive comigo y busca quien te mantenga" Él es tan franco que te dará para esso y para más.

SEMPRONIO - ¡Hai Trae también Pármeno perdidas las suyas; a este cuento, en armas se le yrá su hazienda. ¿Cómo quieres que le sea tan importuno en pedirle más de lo que él de su propio grado haze, pues es arto? No digan por mí que dándome un palmo pido quatro. Dionos las cient monedas, dionos después la cadena. A tres tales aguijones no terná cera en el oýdo; caro le costaría ese negócio. Contentémonos con lo razonable; no lo perdamos todo por querer más de la razón, que quien mucho abarca, poco suele apretar.

CELESTINA - ¡Gracioso es el asno! Por mi vegez, que si sobre comer fuera, que dixera que habíamos todos cargado demasiado. ¿Estás en tu seso, Sempronio? ¿Qué tiene que hazer tu galardón con mi salario, tu soldada con mis mercedes? ¿Só yo obligada a soldar vuestras armas, a cumplir vuestras faltas? Aosadas, que me maten si no te has asido a una 
palabrilla que te dixe el otro día viniendo por la calle: que quanto yo tenía era tuyo, y que en quanto pudiesse con mis pocas fuerças jamás te faltaría, y que, si Dios me diesse buena manderecha con tu amo, que tú no perderías nada. Pues ya sabes, Sempronio, que estos ofrescimientos, estas palabras de buen amor, no obligan. No ha de ser oro quanto reluze; si no, más barato valdría. Dime, ¿estoy en tu coraçon, Sempronio? Verás si, aunque soy vieja, sí acierto lo que tú puedes pensar. Tengo, hijo, en buena fe, más pesar, que se me quiere salir esta alma de enojo. Di a esta loca de Elicia, como vine de tu casa, la cadenilla que traxe, para que se holgasse con ella, y no se puede acordar dónde la puso. Que en toda esa noche ella ni yo no avemos dormido sueño, de pesar. No por su valor de la cadena, que no era mucho, pero por su mal cobro della. Y de mi mala dicha entraron unos conocidos y familiares míos en aquella sazón aquí. Temo no la ayan levado diziendo: "si te vi, burléme" etc. Assí que, hijos, agora que quiero hablar con entramos, si algo vuestro amo a mí me dio, devés mirar que es mío; que de tu jubón de brocado no te pedí yo parte, ni la quiero. Sirvamos todos, que a todos dará según viere que lo merescen; que si me ha dado algo, dos vezes he puesto por él mi vida al tablero. Más herramienta se me ha embotado en su servicio que a vosotros; más materiales he gastado, pues avés de pensar, hijos, que todo me cuesta dinero. Y aun mi saber, que no lo he alcançado holgando, de lo qual fuera buen testigo su madre de Pármeno, ¡Dios aya su alma! Esto trabajé yo; a vosotros se os debe essotro. Esto tengo yo por oficio y trabajo; vosotros por recreación y deleyte. Pues assí, no havés vosotros de aver ygual galardón de holgar que yo de penar. Pero aun con todo lo que he dicho, no os despidáys, si mi cadena parece, de sendos pares de calças de grana, que es el ábito que mejor en los mancebos paresce. Y si no, recebid la voluntad, que yo me callaré con mi pérdida. Y todo esso de buen amor, porque holgastes que hoviese yo antes el provecho destos passos, que no otra. Y si no os contentardes, de vuestro daño farés.

SEMPRONIO - No es esta la primera vez que yo he dicho quánto en los viejos reyna este vicio de cobdicia: quando pobre, franca; quando rica, avarienta. 
Assí que, adquiriendo cresce la cobdicia y la pobreza cobdiciando, y ninguna cosa haze pobre al avariento sino la riqueza. ¡O Dios, y cómo cresce la necessidad con la abundancia! ¡Quién la oyó a esta vieja dezir que me llevasse yo todo el provecho, si quisiesse, deste negócio, pensando que sería poco! Agora que lo vee crescido, no quiere dar nada, por complir el refrán de los niños, que dizen: "de lo poco, poco; de lo mucho, nada".

PÁRMENO - Dete lo que te prometió, o tomémoslo todo. Harto te dezía yo quién era esta vieja, si tú me creyeras.

CELESTINA - Si mucho enojo traes con vosotros o con vuestro amo, o armas, no lo quebréys en mí. Que bien sé dónde nasce esto; bien sé y barrunto de qué pie coxqueáys. No, cierto, de la necessidad que tenéys de lo que pedís, ni aun por la mucha cobdicia que lo tenéys, sino pensando que os he de tener toda vuestra vida atados y cativos con Elicia y Areúsa, sin quereros buscar otras, movéysme estas amenazas de dinero, ponéysme estos temores de la partición. Pues callá, que quien estas os supo acarrear, os dará otras diez, agora que ay más conoscimiento y más razón y más merecido de vuestra parte. Y si sé complir lo que prometo en este caso, dígalo Pármeno. ¡Dilo, dilo, no ayas empacho de contar cómo nos pasó quando a la otra dolía la madre!

SEMPRONIO - Yo dígole que se vaya y abáxase las bragas; no ando por lo que piensas. No entremetas burlas a nuestra demanda, que con ese galgo no tomarás, si yo puedo, más liebres. Déxate comigo de razones. A perro viejo, no cuz, cuz. Danos las dos partes por cuenta de quanto de Calisto has recebido, no quieras que se descubra quién tú eres. ¡A los otros, a los otros con essos halagos, vieja!

CELESTINA - ¿Quién só yo, Sempronio? ¿Quitásteme de la putería? Calla tu lengua, no amengues mis canas, que soy una vieja qual Dios me hizo, no peor que todas. Vivo de mi oficio como cada qual oficial del suyo, muy limpiamente. A quien no me quiere, no le busco. De mi casa me vienen a sacar. En mi casa me ruegan. Si bien o mal vivo, Dios es el testigo de mi coraçón. Y no pienses con tu yra maltratarme, que justicia ay para todos, a todos es ygual; tan bien seré oýda, aunque mujer, como vosotros muy peynados. Déxame en mi casa con mi fortuna. Y tú, 
Pármeno, ¿piensas que soy tu cativa, por saber mis secretos y mi passada vida y los casos que nos acaescieron a mí y a la desdichada de tu madre? ¡Y aun así me tratava ella, quando Dios quería!

PÁRMENO - No me hinches las narizes con essas memorias; si no, embiarte he con nuevas a ella, donde mejor te puedas quexar.

CELESTINA - ¡Elicia, Elicia! ¡Levántate dessa cama, da acá mi manto presto, que, por los sanctos de Dios, para aquella justicia me vaya, bramando como una loca! ¿Qué es esto? ¿Qué quieren decir tales amenazas en mi casa? ¿Con una oveja mansa tenés vosotros manos y braveza? ¿Con una gallina atada? ¿Con una vieja de sesenta años? ¡Allá, allá con los hombres como vosotros! Contra los que ciñen espada mostrá vuestras yras, no contra mi flaca rueca. Señal es de gran covardía acometer a los menores y a los que poco pueden. Las sucias moxcas nunca pican sino los bueyes magros y flacos; los guzques ladradores a los pobres peregrinos aquexan con mayor ímpetu. Si aquella que allí está en aquella cama me oviesse a mí creýdo, jamás quedaría esta casa de noche sin varón, ni dormiríemos a lumbre de pajas, pero por aguardarte, por serte fiel, padescemos esta soledad. Y, como nos veys mujeres, habláis y pedís demasías. Lo qual, si hombre sintiéssedes en la posada, no haríades; que, como dizen: "el duro adversario entibia las yras y sañas".

SEMPRONIO - ¡O vieja avarienta, garganta muerta de sed por dinero! ¿No serás contenta con la tercia parte de lo ganado?

CELESTINA - ¿Qué tercia parte? ¡Vete con Dios de mi casa, tú! Y essotro no dé vozes, no allegue la vezindad. No me hagáys salir de seso. No queráys que salgan a plaza las cosas de Calisto y vuestras.

SEMPRONIO - Da vozes o gritos, que tú compliras lo que tú prometiste, o se complirán oy tus días.

ELICIA $\quad-$ ¡Mete, por Dios, el espada! Tenle, Pármeno, tenle; no la mate esse desvariado.

CELESTINA - ¡Justicia, justicia, señores vezinos! ¡Justicia, que me matan en mi casa estos rufianes!

SEMPRONIO - ¿Rufianes, o qué? ¡Espera, doña hechizera, que yo te haré yr al infierno con cartas! 
CELESTINA - - Ay, que me ha muerto! ¡Ay, ay! ¡Confessión, confessión!

PÁRMENO - ¡Dale, dale, acábala, pues començaste, que nos sentirán! ¡Muera, muera! ¡De los enemigos, los menos!

CELESTINA - ¡Confessión!

ELICIA $\quad-¡ \mathrm{O}$ crueles enemigos! ¡En mal poder os veáys! ¡Y para quién tovistes manos! ¡Muerta es mi madre y mi bien todo!

SEMPRONIO - ¡Huye, huye, Pármeno, que carga mucha gente! ¡Guarte, guarte, que viene el alguazil!

PÁRMENO - ¡O pecador de mí! ¡Que no ay por dó nos vamos, que está tomada la puerta!

SEMPRONIO - ¡Saltemos destas ventanas. No muramos en poder de justicia.

PÁRMENO - ¡Salta, que tras ti voy! 


\section{BIBLIOGRAFIA}

AMOSSY, Ruth. Imagens de si no seu discurso - a construção do éthos. São Paulo: Contexto, 2005.

ARROYO, Ciriaco Morón. Sentido y forma de la Celestina. Madrid: Cátedra, 1984.

ASCHER, Nisso. ¿Una lectura marrana de La Celestina? in

http://www.chasque.apc.org/frontpage/relacion/0101/celestina.htm

(outubro/2008)

BARTHES, R. O Rumor da língua. São Paulo: Brasiliense, 1987.

BAKHTIN, M. (Voloshinov,V.N.1980). Écrits sur le freudisme. Paris: L'Age D'homme (Voloshinov, V.N.-1929). Marxismo e filosofia da linguagem. São Paulo: Hucitec, 1992.

BAKHTIN, Mikhael. Problemas da poética de Dostoiévski. Rio de Janeiro: Forense-Universitária, 1981.

BAKHTIN, Mikhail [VOLOCHINOV, V. N.]. Marxismo e filosofia $d a$ linguagem. Problemas fundamentais do método sociológico na ciência da linguagem. Tradução de Michel Lahud e Yara Frateschi Vieira. 6. ed. São Paulo: Hucitec, 1992.

BAKHTIN, Mikhail. Os gêneros do discurso. In: . Estética da criação verbal. Tradução de Paulo Bezerra do título em russo Estetika sloviésnova tvórtchestva. 4. ed. São Paulo: Martins Fontes, 2003.

BARANDA LETURIO, C. e VIAN HERRERO, A. M. El nacimiento crítico del "género" celestinesco: história y perspectiva. Madrid: Instituto Universitario Menéndez Pidal y Complutense, 2006

BARROS, D. L. P. de. "Contribuições de Bakhtin às teorias do discurso". In: Brait, B. (Org.). Bakhtin, dialogismo e construção do sentido. São Paulo, Editora da Unicamp, 1997.

BATAILLON, Marcel. Erasmo y Espana. Estudios sobre la história espiritual del siglo XVI. México: Fondo de Cultura Económica, 1982.

BERGAMÍN, José. Rojas, mensajero del infierno: releyendo La Celestina. Montevideo. Revista de la Facultad de Humanidades y Ciencias, VI, número 9, 1952.

BERNDT, Erna Ruth. Amor, muerte y fortuna en "La Celestina”. Madrid: Gredos, 1963.

BRAIT, Beth. A personagem. São Paulo: Ática, 1993. 
BRAIT, Beth. Bakhtin: outros conceitos-chaves. São Paulo: Contexto, 2006.

BRETON, Philippe. A argumentação na comunicação. Bauru: EDUSC, 1999.

BUHLER, Karl. Sprachtheorie. Die Darstellungsfunktion der Sprache (1934) Jena, Fischer, traduzido por Julián Marías: Teoria da linguagem. Madrid: Revista de Occidente, 1950.

CALDERÓN, Demetrio Estébanez. La Celestina, texto clave en la crisis de los valores medievales y en la génesis del humanismo renacentista in http://www.ausape.wz.cz/?id=121 (consulta fevereiro de 2010)

CÂNDIDO, A., ROSENFELD, A, ALMEIDA PRADO, D., SALlES GOMES, P. E. A personagem de ficção. São Paulo: Perspectiva, 2004.

CARDONA, Rodolfo y ZAHAREAS, Anthony N. Visión del esperpento. 2a, Madrid: Castalia, 1987.

CASTRO, A. y SANCHEZ ALBORNOZ, C. Dos concepciones historiográficas hispanas. In http://manueljofre.blogspot.com/2005/08/americo-castro-y-claudio-sanchez.html $(24 / 08 / 2005)$

CASTRO, Américo. La Celestina como contienda literaria: (castas y casticicismos). Madrid: Revista de Occidente, 1965

CASTRO, Américo. España en su história, Cristianos, Moros y Judios. Barcelona: Crítica (Grijalbo Mondadori), 1983.

CITELLI, Adilson. Linguagem e Persuasão. São Paulo: Ática, 1988.

DAYOUB, Khazzoun Mirched. A ordem das ideias. Palavra, imagem, persuasão: a retórica. São Paulo: Manole, 2004.

DEYERMOND, A. D. La Edad Media. Barcelona: Seix Barral, 1979.

DUCROT, O. O dizer e o dito. Campinas: Pontes, 1987.

FOTHERGILL-PAYNE, Louise. La Celestina: un libro hondamente senequista. A. David Kossoff, José Amor y Vázquez, Ruth H. Kossoff y Geoffrey W. Ribbans, eds. Actas del VIII Congreso de la Asociación Internacional de Hispanistas (1983). Madrid: Ediciones Istmo, 1986.

GALÁN, Eduardo. Claves de La Celestina. Madrid: Ciclo, 1989

GARCÍA, Luis Rubio. Estudios sobre La Celestina. Murcia: Departamento de Filología románica de la Universidad de Murcia, 1985

GILMAN, Stephen, La España de Fernando de Rojas. Panorama intelectual y social de "La Celestina. Madrid: Turus, 1978. 
GILMAN, Stephen. La Celestina: Arte y Estructura. Trad. de Margit Frenk de Alatorre. Madrid: Taurus, 1978;

GONZÁLEZ, M. M. De Rojas a Valle-Inclán: Esperpentismo y modernidad en La Celestina. ROJO, Sara (Org.). Anais do V Congresso Brasileiro de Hispanistas e I Congresso Internacional da Associação Brasileira de Hispanistas. Belo Horizonte: Faculdade de Letras da UFMG, 2009 (CD). ISBN: 978-857758-064-4.

EIKHENBAUM, B. et alii. Teoria da Literatura. Porto Alegre: Globo, 1976.

FERNANDES, Ana Raquel Lourenço. O feminino na literatura picaresca do século de Ouro espanhol in IV Congresso Internacional da associação Portuguesa de Literatura Comparada.

FIORIN, José Luiz. Elementos de análise do discurso. São Paulo: Contexto, 2005 .

FONTANILLE, Jacques. Semiótica do discurso. São Paulo: Contexto, 2005

FORSTER, Edward M. Aspectos do romance. São Paulo: Globo, 1998.

GENETTE, Gérard. Palimpsestes. Paris: Seuil, 1982.

GILMAN, Stephen. La España de Fernando de Rojas. Panorama Intelectual y Social de "La Celestina". Madrid: Taurus, 1978

GONZÁlEZ, Mario. Celestina: o diálogo paradoxal. Cuadernos de Recienvenido, n. 2. São Paulo: Universidade de São Paulo, FFLCH, 1960. . Leituras de Literatura Espanhola (da Idade Média ao século XVII). São Paulo: Letraviva, 2010.

GRACIO, Rui Alexandre. Racionalidade argumentativa. Porto: Asa, 1993.

GURZA, Esperanza. Lectura existencialista de "La Celestina”. Madrid: Gredos, 1977.

HERRERA JIMÉNEZ, Francisco José. Sobre la ganância en la materia celestinesca. 1997 in http://parnaseo.uv.es/lemir/Revista/Revista2/Herrera/Herrera.html . El mundo de la mujer en la materia celestinesca: personajes y contexto. Alicante: Biblioteca Virtual Miguel de Cervantes, 2001.

LACARRA, M. E., Cómo leer La Celestina. Madrid: Júcar, 1990.

LAUSBERG, Heinrich. Elementos de Retórica Literária. Lisboa: Fundação Calouste Gulbenkian, 2004.

LIDA MALKIEL, María Rosa. La originalidad artística de La Celestina. Buenos Aires: Eudeba, 1962. 
LOPES, Edward. Metáfora: da retórica à semiótica. São Paulo: Atual, 1986.

LUKÁCS, Georg. A Teoria do Romance. São Paulo: Duas Cidades Editora 34, 2000.

MAESTRO, Jesús G. Tragedia, comedia y canon desde la teoría literaria moderna. El personaje nihilista de La Celestina. Universidad de Vigo, 2000.

MAESTRO, Jesús G. El personaje nihilista. La Celestina y el teatro europeo. Madrid / Frankfurt am Main: Iberoamericana / Vervuert, 2001.

MAEZTU, Ramiro de. Don Quijote, Don Juan y La Celestina. Madrid: Espalsa Calpe,1972.

MAINGUENEAU, Dominique. Pragmática do discurso literário. São Paulo: Martins Fontes, 2002.

MARAVALL, J. A. El mundo social de La Celestina. Madrid: Gredos, 1981.

MARIOTTI, H. Complexidade e pensamento complexo: breve introdução e desafios atuais in

http://api.ning.com/files/S4Fa15pHbggJI7UgeoRWEKOd3gg4wKHInUumxfdR Ubqynls9YLhpbcRcIvy58Gsp6loQ1EuZ1HHZB46KTIIF*4XgBrPE68n0/Complexidad eMariotti.pdf (acesso novembro de 2010).

MARTÍN-SANTOS, Luis. Tiempo de Silencio. Barcelona: Seix-Barral, 2001.

MENÉNDEZ Y PELAYO, Marcelino. Orígenes de la 9la, t. III. Madrid: Bailly/Baillière, 1910.

MEYER, Michel. A retórica. São Paulo, Ática, 2007.

McPHEETERS, Dean W. Alegorismo, epicureismo y estoicismo escolástico en La Celestina. Eugenio de Bustos Tovar, Actas del IV Congreso de la Asociación Internacional de Hispanistas, 1971.

MIGUEL MARTÍNEZ, Emilio de. La Celestina de Rojas. Madrid: Gredos, 1996.

MOHENO, Lillian von der Walde. El cuerpo de Celestina: un estudio sobre fisonomía y personalidad in eHumanista: Volume 9, 2007.

MOTA, Ana Raquel (org.), SALGADO, Luciana (org.) Éthos Discursivo. São Paulo: Contexto, 2005.

MUIR, Edwin. A estrutura do romance. Porto Alegre: Globo, 1928.

PARRET, H. A estética da comunicação. Campinas: Unicamp, 1997.

PASCHOAL, Stéfano. Tradução da Carta de Sêneca sobre a diversidade na leitura in Revista Trama - Volume 3 - Número 5 - 1 Semestre de 2007 - p. 199-200 
PERELMAN, Chaïm \& OLBRECHTS-TYTECA, Lucie. Tratado da argumentação: a nova retórica. [prefácio Fábio Ulhôa Coelho; tradução Maria Ermantina Galvão G. Pereira]. São Paulo: Martins Fontes, 1996.

PERELMAN, Chaïm. Argumentação. In Enciclopédia Einaudi - vol.11, Lisboa: Imprensa Nacional-Casa da Moeda, 1987.

PERELMAN, Chaïm. La lógica jurídica y la nueva retórica. Madrid: Civitas, 1988.

PUÉRTOLAS, Julio Rodríguez. Nueva aproximación a La Celestina. Madrid: Gredos, 1972.

RAMOS, Teresa Cecília de Oliveira. Alguns aspectos da religiosidade em La Celestina, de Fernando de Rojas. 2. Congresso. Brasileiro de Hispanistas. São Paulo, USP. Oct. 2002 in

http://www.proceedings.scielo.br/scielo.php?

pid=MSC0000000012002000200045\&script=sci_arttext

RAUEN, F. Tratado de argumentação de Perelman e Olbrechts-Tyteca: resenha. Ágora, Caçador, v. 4, n. 2, pp. 172 - 183, 1997.

REBOUL, Olivier.(2000) Introdução à retórica. Trad. Ivone Castilho Benedetti. São Paulo: Martins Fontes.

Revisión crítica de "Libro de Buen Amor" por: Estudiantes de la Universidad de Arkansas. in

http://64.233.169.104/search?

q=cache:liLoi56M7_EJ:galeon.com/nuestroidioma/directorio/buenamor.html+libro+del +buen+amor+trotaconvento\&hl=pt-BR\&ct $=\mathrm{clnk} \& \mathrm{~cd}=1 \& \mathrm{gl}=$ br $\quad$ (consulta março de 2009)

RODRIGUEZ-PUÉRTOLAS, Julio. Literatura, história,alienación. Barcelona: Labor, 1976.

RUIZ, Juan. El Libro de Buen Amor. Alicante: Biblioteca de Magisterio de la Universidad de Alicante, 2000.

RUIZ RAMÓN, Francisco. História del teatro español. (Desde sus orígenes hasta 1900). Madrid: Cátedra, 1981.

RUIZ RAMÓN, Francisco. História del teatro español. Siglo XX. Madrid: Cátedra, 1981(a). 
RUSSELl, Peter E. La Celestina. Comedia o Tragicomedia de Calisto y Melibea. Ed. de Peter E. Russell. Madrid: Clásicos Castalia, 1991.

RUSSELL, Peter E. Tradición literaria y realidad social en La Celestina in http://www.cervantesvirtual.com/servlet/SirveObras/12482842009137183087846/p0000001.ht $\mathrm{m}$

SALVADOR MIGUEL, Nicasio, La identidad de Fernando de Rojas, en Celestina. La comedia de Calisto y Melibea, locos enamorados. Madrid: Sociedad Estatal España Nuevo Milenio, 2001.

SALVADOR MOSCA, Espaço tensivo da controvérsia: uma abordagem discursivo-argumentativa. In Revista de Filologia n 9, 2007, pp. 293-310.

SAN PEDRO, Diego. Obras completas, II: Cárcel de amor. Madrid: Keith Whinnom, Clásicos Castalia, 1971.

SEGOLIN, Fernando. Personagem e anti-personagem. São Paulo: Cortez \& Moraes Ltda, 1978

SODRÉ, Paulo Roberto. Entre a guarda e o viço: a madre nas cantigas de amigo galego-portuguesas. in Temas Medievales. v.12 n.1 Buenos Aires ene./dic. 2004

SOTO RIVERA, Rubén. Celestina, la de la cuchillada in http://cuhwww.upr.clu.edu/exegesis/33/soto.html, consultado em março de 2009

SPINOZA, Yovel Yermihau. El Marrano de la Razón, capítulo "Marranos enmascarados y mundo sin trascendencia: Fernando de Rojas y La Celestina”, Madrid: Anaya y Mario Muchnik, 1995.

TODOROV, T. (1979). "Prefácio". In: Bakhtin. Estética da criação verbal. São Paulo, Martins Fontes, 1992b.

TODOROV, T. (1981). Mikhail Bakhtine. Le principe dialogique. Paris, Seuil.

VALLE-INCLÁN, Joaquín y Javier del. Entrevistas, conferencias y cartas. Ramón María del Valle-Inclán. Valencia, Pré-Textos, 1995.

VALLE LERSUNDI, F., Estamento de Fernando de Rojas, autor de La Celestina. Madrid: Revista de Filología Española, XVI, 1929.

VILLANUEVA, F. M. Orígenes y sociología del tema celestinesco. Barcelona: Anthropos, 1993.

VIGNEAUX, G. (1976). L'argumentation - essai d'une logique discoursive. Genève: Droz.

WARDROPPER, Bruce W. El mundo sentimental de la Cárcel de amor, Revista de Filología Española, XXX. 